\title{
A new starting point for the South and Equatorial Atlantic Ocean
}

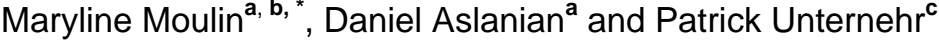 \\ a Ifremer Centre de Brest, DRO/Géosciences Marines, B.P. 70, 29280 Plouzané Cedex (France) \\ ${ }^{b}$ IDL-LATTEX, Instituto Dom Luiz, Laboratorio de Tectonofisica e Tectonica Experimental, Faculdade de Ciências \\ da Universidade de Lisboa, Edificio C6, Campo Grande, 1749-016 Lisboa, Portugal \\ ${ }^{c}$ Total, Exploration Production/Géosciences/Projets Nouveaux/Expertise Géodynamique, 2, place de la Coupole - \\ La Défense 6, 92078 Paris la Défense Cedex, France \\ *: Corresponding author : Maryline Moulin, Tel.: +351 21 7500000x26269; fax: +351 21 7500119, email address : \\ mmoulin@fc.ul.pt \\ daniel.aslanian@ifremer.fr, Patrick.UNTERNEHR@total.com
}

\begin{abstract}
:
The opening of the Equatorial and South Atlantic Oceans is still a matter of debate, particularly as concerns the locations of the intraplate deformation. We propose here a critical review of the kinematic models published since Bullard et al., 1965, based on a series of constraints: new interpretation of the magnetic anomalies, seafloor isochrons, flow lines, fracture zones, continental and oceanic homologous structures and radiometric dating of igneous rocks. All of these models present numerous unexplained misfits (gaps, overlaps and misalignments). We present here a new evolution of the Equatorial and South Atlantic Ocean from the tightest reconstruction to Chron C34. This new model confirms the hypothesis of a northward propagation of the South American deformation proposed by Eagles, but rejuvenates slightly the ages for this propagation and refines the plate reconstructions. In particular, we highlight the role of the kinematic «buffer» Santos block, located between the salty Aptian Central segment in the North and the Volcanic Hauterivian Austral segment in the South. The new initial fit presented in this study represents the tightest reconstruction that could be obtained and constitutes the base canvas on which the problem of the continental margin genesis should be addressed.
\end{abstract}

Keywords: initial kinematic reconstruction; South and Equatorial Atlantic Oceans; intraplate deformation; magnetic anomalies 


\section{Introduction}

Several authors have tried to solve the problem of the pre-opening fit in the South Atlantic Ocean in the past. Nevertheless, even the most recent entire reconstructions of the break-up history (Nürnberg \& Müller, 1991, Lawver et al., 1999, Schettino \& Scotese, 2005, Eagles, 2006, Konïg \& Jokat, 2006, Torsvik et al., 2009) present numerous unexplained misfits (gaps, overlaps and misalignments) that we will show and analyse in this review. Attempts to obtain the pre-opening fit (and to evaluate its age) and the early evolution of an ocean are also strongly dependent on the hypothesis made for the location of the first typical oceanic crust and often require an assessment of the rigidity of surrounding plates. This procedure has been undertaken for the South Atlantic Ocean (Burke \& Dewey, 1974; Pindell \& Dewey, 1982; Curie, 1984; Unternehr et al. 1988; Nürnberg \& Müller, 1991; Lawver et al., 1999; Dickson et al., 2003; Macdonald et al., 2003; Eagles, 2006; Torsvik et al., 2009) and for the Central Atlantic (Olivet, 1984, Olivet et al., 1996, Sahabi et al., 2004, etc.). In the central segment of the South Atlantic Ocean, this work is complicated by the lack of well-defined magnetic anomalies in the early history of the ocean.

The aim of this work is to reassess the plate tectonics kinematics in this region in order to 1) obtain the tightest pre-opening reconstruction without unacceptable misfits 2) obtain the precise evolution of the opening of the South and Equatorial Atlantic Oceans, taking into account all geological and geophysical constraints and 3) discuss the probable existence, the location and evolution of the intraplate deformation during the opening of the South Atlantic Ocean.

\section{The South Atlantic Ocean: early history, main structures and hypotheses.}

The mega-continent Pangea was the result of an aggregation of two super continents, Laurasia and Gondwana, which formed the Caledonian-Hercynian Mountains during the permo-triassic period (Figure 1). At the end of the Triassic, the break-up of the megacontinent occurred asynchronously on an ancient suture zone and corresponds to three phases:

1- The first signs of the distension within Pangea started in the Trias; the separation between the Gondwana and the Laurentia began in the Late Sinemurian (Sahabi et al., 2004) with a rifting marked by major igneous eruptions in the Central Atlantic Magmatic Province (CAMP) dated about 200Ma (May, 1971; Bertrand \& Westphal, 1977; Marzoli et al., 1999b). Within the Gondwana, the disruption occured during the early Jurassic, between Africa and South America and between Australia, Antarctica, Madagascar and Indus (Norton \& Sclater, 1979; Patriat et al., 1982; Eagles \& Konig, 2008) coinciding with the Karoo volcanism. Those disruptions (red lines on figure 1) created three mega-blocks that now form the oldest in situ margins known in the world.

2- During the Early Cretaceous, around the magnetic anomaly M0 (around $125 \mathrm{Ma}$, Gradstein et al., 2004) that marked the beginning of the quiet magnetic period, a new configuration took place: the three super-blocks further subdivided into smaller blocks (green lines on figure 1). This new disruption initiated the formation of the North Atlantic Ocean, between North America and Greenland, forming the Labrador Sea (Watt, 1969; Austin \& Howie, 1973), and between North America and Europe - Iberia in the south, extending to the Bay of Biscay (Pitman \& Talwani, 1972; Kristoffersen, 1978; Olivet et al., 1984, Olivet, 1996). The Early Cretaceous breakup afftected the northern and eastern margins of Antarctica, forming the North and SW Indian Ocean (Norton \& Sclater, 1979; Sahabi, 1993), which separated the Indian and Australian continents. The South Atlantic Ocean also opened during this period, mainly on the Pan-African suture in the south, but also disrupting the E-W 
segment of the São Francisco - Sangha cratons in the north (Heilbron et al., 2000; Aslanian et al., 2009).

3- Last, a third generation of disruption (blue lines on Figure 1) occurred during the Tertiary period, in the Red Sea, the Gulf of Aden (Laugthon et al., 1970; Girdler \& Styles, 1978; Cochran, 1982) and the Norwegian Sea, separating Greenland from Scandinavia (Talwani \& Eldholm, 1977; Olivet, 1978; Unternehr, 1982; Nunns, 1983). Rifting in the Labrador Sea was thus extincted and the active spreading center moved to the east forming a massive lava flow province between Greenland and Norway and eventually resulting in the present-day midAtlantic ridge located in Iceland (White, 1992; Srivastava \& Roest, 1999).

Focusing on the South Atlantic Ocean, it can be divided into four $\sim 2000 \mathrm{~km}$-long segments (Figure 2): from North to South, the Equatorial segment, the Central segment, the Austral Segment (Popoff, 1988) and the Falkland Segment.

The Equatorial segment is separated from the Central Atlantic Ocean by the Marathon Fracture Zones, to the north of the Demerara and Guinean plateaus (Figure 2). Its southern limit, marked by Romanche and Chain Fracture Zones, north to the Potiguar Basin, corresponds to the Ivory Coast and Ghana transform system and its Brazilian homologous margins (Hayes \& Ewing, 1970, Le Pichon \& Hayes, 1971; Mohriak, 2004). In between, a strongly segmented oceanic ridge gives rise to the link between the shifted Central and South Atlantic Ridges. Despite the lack of magnetic lineaments due to its position close to the Equator, the beginning of the seafloor spreading in this segment is dated to the upper Albian (Oliveira Marinho, 1985; Blarez, 1986; Gouyet, 1988).

The Central segment (sightly larger than the tropical segment of Popoff (1988), which starts at Ascension FZ in the North), is positioned between the Benue Trough to the North and the Rio Grande Fracture Zones to the South, and is characterized by the presence of a large evaporitic basin, developed in the Aptian (Brognon \& Verrier, 1966; Reyre, 1966; Butler, 1970; Asmus \& Ponte, 1973; Leyden et al., 1976; Asmus, 1984; Mohriak \& Rosendahl, 2003). The seafloor spreading in this region began after the Barremian age, during the quiet magnetic time in Early Cretaceous time (after chron M0), so that no magnetic lineament marks the beginning of the oceanic crust accretion. Some authors (Mohriak, 2001) proposed an oceanic crust propagators such as the Abimael Ridge advancing from the Pelotas basin in the south towards the southern Santos Basin in the north impinge on the salt basin.

The Austral Segment is limited between the Rio Grande Fracture Zones to the North and the Falkland-Agulhas Fracture Zones to the South. The seafloor spreading began during the early Cretaceous (Rabinowitz \& LaBrecque, 1979), but debate still remains about the age of the magnetic anomalies observed in this area. This segment is characterized by the presence of Seaward Dipping Reflectors (SDRs), which indicate the presence of volcanism during the genesis of the margin, indicated both along the Brazilian and Argentine basins and their conjugates Namibia - South Africa (Hinz, 1981; Talwani \& Abreu, 2000; Franke et al., 2007).

The Falkland Segment is the junction between the Atlantic ridge and the South Western Indian Ridge (SWIR). It is complicated by the presence of the fossil Agulhas ridge. The seafloor spreading is presumed to have begun around $134 \mathrm{Ma}$ at M10 (Rabinowitz et al., 1976, Goodlad et al., 1982, Martin et al., 1982). The formation of this segment, linked to the movement of the Antarctica plate, will not be discussed in this paper.

\subsection{Geophysical and geological data used as kinematic constraints}

Fracture zones have been proved to be powerful and precise data to constrain the relative movements between two plates (Rabinowitz \& Labrecque, 1979; Olivet et al., 1984, Cande et al., 1988; Fidalgo, 2001; Labails, 2007), particularly in the Equatorial Ocean where magnetic 
data are lacking (Campan, 1995). In the Central and Austral segments however, despite the fact that a large number of linear anomalies are evident on the $1 \mathrm{mn} \times 1 \mathrm{mn}$ satellite-derived free air gravity data (Sandwell \& Smith's, 1997), very few of them can be prolonged towards the continents because of the thick sedimentary layers that mask and complicate the gravity response: to constrain the initial reconstruction, we therefore principally used three main Fracture Zones (Ascension, Rio Grande and Agulhas-Falkland FZs) and some minor fracture zones in the Southern segment (Figure 2).

We compiled and re-interpreted magnetic data on both sides of the Austral Segment:

On the African side (Figure 3), we compiled the magnetic profiles of Rabinowitz (1976) and Rabinowitz \& Labrecque (1979), the NGDC profiles (Geodas world data base), two magnetic profiles of Bauer et al. (2000) and the magnetic map of Corner et al. (2002) in Walvis Basin, and BGR magnetic map (web site: //www.bgr.bund.de/, contact Dr. Bernd Schreckenberger) in the southern part of the Orange Basin. On the American side (Figure 4), we compiled the magnetic profiles of Cande \& Rabinowitz (1978), Rabinowitz \& Labrecque (1979) and Hinz et al. (1999), the NGDC profiles (Geodas world data base), the aero-magnetic profiles and map of Max et al., (1999) in the Argentine Basins, BGR magnetic map (web site: //www.bgr.bund.de/, contact Dr. Bernd Schreckenberger) in the Colorado Basin, the magnetic maps of Zalan \& de Oliveira (2005) and an industrial magnetic map of the Pelotas Basin.

Despite general agreement, our new interpretation differs from that of Rabinowitz \& Labrecque (1979), mainly because we had access to additional data on both sides of the ocean (see Figures $3 \& 4$ ):

- $\quad$ in the Orange basin, M11 and M9 anomalies of Rabinowitz \& Labrecque (1979) are hardly recognizable and probably over-interpreted; they do not exist on the South American side. We therefore grouped them and the $G$ anomaly into the new anomaly called Large Marginal Anomaly (LMA). This continuous anomaly is therefore characterized by large amplitude and irregular width signature (see Figure 4 in Corner et al., 2002), similar to the ECMA and WACMA in the Central Atlantic Ocean (Vogt et al., 1973; Sahabi et al., 2004). In the Orange Basin, the LMA presents a double branch (the previous $G$ anomaly for Rabinowitz \& Labrecque, 1979). Offshore the Argentine Basins, south of $37^{\circ} \mathrm{S}$, the LMA also corresponds to the G anomaly of Rabinowitz \& Labrecque (1979). In the Pelotas basin, however, and based on an industrial magnetic map, we reinterpreted their G anomaly as M4 anomaly. LMA and G anomalies are therefore shifted to the west, north of the Salado Basin. Note that the South American LMA does not present a southern double branch shape, contrary to the African LMA. Whereas the M7 anomaly can be defined in the southern part of the Orange Basin (Figure 3) and offshore Rawson Basin (Figure 4), the M9 anomaly is hardly recognizable on both sides of the Atlantic.

- $\quad$ North of $24^{\circ} \mathrm{S}$ on the African margin, Rabinowitz and LaBrecque (1979) shifted the M4 anomaly to the west. Based on the Corner et al. (2002) magnetic map, our interpretation for the M4 anomaly is positioned further to the east. 
- $\quad$ On the South American side, our M4 interpretation is similar to the interpretations of Hinz et al. (1999) and Max et al. (1999) between $43^{\circ} \mathrm{S}$ and $45^{\circ} \mathrm{S}$. South of $45^{\circ} \mathrm{S}$, we re-interpreted the M2 anomaly of Max et al. (1999) as the southern branch of the M4, following the interpretation of Hinz et al. (1999). North of the Salado Basin, we re-interpreted, using an industrial magnetic map, the G anomaly of Rabinowitz and LaBrecque (1979) as the northern part of the M4 South American anomaly. North of Salado Basin, our interpretation therefore shows a westward shift of both chron M4 and LMA. The large Rio de La Plata estuary between Montevideo and Buenos Aires (36-37'S) might have been implanted on a weakness zone associated with this lineament.

- In the Walvis basin, we defined, on the base of up-dated NGDC database and the Corner et al. magnetic map (2002), a new MO anomaly that give rise to a continuous M0-M2-M4-LMA sequence along the African margin, without any shift.

- In Pelotas Basin, we defined a M2 anomaly (its western limit corresponds to the M3 anomaly of Rabinowitz \& Labrecque, 1979) that allows positioning a continuous M0-M2 sequence along the American margin, without any shift.

It is worth noting the good correspondence between the "LMA" and the SDRs in the Argentine Basins (south of $37^{\circ} \mathrm{S}$; Hinz et al., 1999, Franke et al., 2006; Moulin et al., 2006). On the African side, the BGR-16 profile (near Cape Town; Total, pers. comm.) also shows a coincidence between SDRs and the LMA. Towards the north (in the Pelotas and Orange basin), this correspondence is not so clear. However, Fontana (1996) and Cainelli \& Mohriak (1998) interpreted the feather edge of the seaward-dipping reflector wedge imaged in the Pelotas Basin to correspond to a marked magnetic anomaly (Mohriak, pers. com.)

In addition to the well-defined fractures zones and the magnetic lineaments, we also used offshore and onshore conjugate systems to constrain the kinematic reconstructions (Figure 2):

- In the Equatorial Segment, the Demerara and Guinean plateaus in the north (Gouyet, 1988, Gebco97, Digital Atlas Web Site: www.nbi.ac.uk) and the Kandi (Guiraud \& Alidou, 1981) and Sobral lineaments (Gouyet, 1988; Caby, 1989) on both plates, which represent the same Panafrican fault zone (Gouyet, 1988, Caby, 1989).

- In the Central Segment, the Panafrican fault systems Ngaoundéré - Sanaga lineaments (Black \& Girod, 1970 in Cornacchia \& Dars (1983); Dumont, 1986, 1987) and Patos - Pernambuco lineaments (Almeida \& Black, 1967, in 
Cornacchia \& Dars, 1983; Almeida et al., 1970). In this segment, we also used the internal and external Aptian salt boundaries (in pink on Figure 2), drawn using the compilations of Butler (1970), Mascle \& Renard (1976), Curie, (1984) (based on Franks \& Nairn, 1973, Pautot et al., 1973, Leyden et al., 1976 and Lehner \& De Ruiter, 1977) and Heilbron et al. (2000), and our own seismic re-interpretation of several seismic cruises: WALDA (Pautot et al., 1973; Renard \& Mascle, 1974), VEMA (Leyden et al., 1972); Atlantis II (Emery et al., 1975), PROBE (Rosendahl et al., 1991; Rosendahl \& Groschel-Becker, 1999; Meyers et al., 1996), published industrial profiles (Marton et al., 2000), ZAIANGO (Contrucci et al., 2004, Moulin et al., 2005) and an industrial compilation for the Brazilian side (Unternehr, comm. pers). The Hinge Lines associated with the proximal rift border fault are drawn according to an industrial compilation (Unternehr, comm. pers.), Heilbron et al., 2000, Karner \& Driscoll, 1999 and industrial seismic profiles (Moulin et al., 2006).

- In the Austral segment, we used the limits of the SDRs, according to Bauer et al., (2000) for the African side and our seismic interpretation of industrial profiles (Gondcalves de Souza, 1991 and Moulin et al., 2006) for the South American side. The limits of the Paraná Province and dyke positions comes from a compilation of results of Almeida et al. (1970), Jacques (2003a; 2003b), Turner et al. (1994), Araujo et al. (2000) and Marzoli et al. (1999a). The conjugate limit of Etendeka province comes from the geological map of Africa (Choubert et al., 1968).

\subsection{Plate reconstruction software: PLACA}

All this kinematic work was conducted using the open-source PLACA software (Matias et al., 2005). This software was developed for earth scientists working on the plate tectonics theory. It enables the representation of plate reconstructions and the determination of best-fit poles using magnetic anomalies, fracture zones or volcanic alignments. The bestfit poles can be computed either visually (for example with the method of Olivet (1978) and Bonnin (1978)) or by systematic routine search. Once the best-fit pole is obtained, several statistical tests can be made to evaluate the confidence of the fit. This code is free of access at http://www.ifremer.fr/drogm/telechargement/placa_version_0_1.

\subsection{First Models: rigid plates hypothesis}

In 1965, on the basis of the work of Carey (1955), Bullard et al. proposed the first South Atlantic Ocean statistical reconstruction (Figure 5-A). The authors pointed out a geometrical problem: how can we reconstruct the initial pre-opening fit both in the Equatorial and South Atlantic Oceans at the same time?

The first trials to resolve this problem implied rigid plates, without any intraplate deformations. 
Following Bullard et al. (1965), many authors (Dietz, 1973, Mascle \& Sibuet, 1974, Smith \& Briden, 1977, and Sibuet \& Mascle, 1978) proposed a synchronised opening of the whole South Atlantic Ocean. As Figure 5-A shows, the adjustment of the southern and northern parts of the South Atlantic is impossible to carry out with this assumption (see the gaps, in blue on the figure). In Bullard's model, for instance, the fit of the South Atlantic implies a huge gap in the Equatorial segment, leading Sibuet \& Mascle (1978) to propose that this gap was occupied by the western part of the Bahamas platform and part of Cuba Island.

Following these attempts, and on the basis of newly identified Mesozoic magnetic anomalies in the Austral segment, Rabinowitz \& LaBrecque (1979) proposed a diachronic opening of the Central and Austral segments (Figure 5-B). Their fit, at Valanginian time (130 $\mathrm{Ma}$ ), is close to Bullard's pre-drift reconstruction, with a $200 \mathrm{~km}-\mathrm{gap}$ between the Guinea and Demerara plateaus (dotted lines in Figure 5-B). The movement given by their pole at $2.5^{\circ} \mathrm{S}$ and $45^{\circ} \mathrm{W}$ allows for an opening of the Austral segment at Valanginian time and of the Central segment at Aptian time (113 Ma), but of course, due to the position of the pole, implies a $300 \mathrm{~km}$ large compression in the north, between the plateaus of Guinea and Demerara (in green on Figure 5B), which is inconsistent with geological observations (Oliveira Marinho, 1985; Gouyet, 1988).

The last attempts with fully rigid plate assumption involved the hypothesis of a rift propagation (Vink, 1982; Martin, 1984). In order to avoid any gap, Vink (1982) proposed a fit with many overlaps (Figure 5-C). This reconstruction is built up from the Rabinowitz \& LaBrecque Aptian reconstruction with a supplementary movement with a pole around Demerara and Guinea plateaus (in Aptian position) to avoid the gaps in the South Atlantic Ocean. The resulting overlaps are assumed to result from differential stretching (the more overlapped, the more stretched) due to the propagation of the rifting, which therefore is progressive and diachronic (Figure 5-D-a). However, this reconstruction shows extremely significant overlaps in the Benue Trough and in the Central segment, totally incompatible with the geological constraints, and implies huge differences in the stretching processes (Martin, 1984). Martin therefore proposed, following an idea of Courtillot (1982), that this propagation of rifting is a natural consequence of relative movements starting from a close pole of rotation. The rotation induces a stretching of the lithosphere until a critical distance, $x$, where the oceanic accretion occurs. As separation increases, the critical value $x$ moves northwards. If we assume that the critical distance may change along the plate boundaries, windows of rift propagation can be created on a smaller scale. Despite the fact that a rotation pole in the Benue will have strong consequences in the Equatorial segment, Figure 5-D-b shows that the resulting magnetic lineaments created with this model are oblique to the margin, with an angle pointing towards the north, whereas the Mesozoic magnetic anomalies in the Austral segment are parallel to the coast (Rabinowitz \& LaBrecque, 1979, and this study), rendering this model unacceptable also.

\subsection{Introduction of the Intraplate deformation}

At the same time, Burke \& Dewey (1974) explored the idea of continental intraplate deformation. In order to close both the Equatorial and South Atlantic Oceans (at the same time), they suggested introducing an intraplate deformation in the Africa plate at the Benue Trough. This trough was interpreted as an aborted third branch of a triple junction RidgeRidge-Ridge during the Santonian, in relation to the presence of a hot spot.

Following Burke \& Dewey's hypothesis, several authors focused on African intraplate deformation as the only solution to the kinematic problem (Pindell and Dewey, 1982; Fairhead, 1988; Guiraud \& Maurin, 1992).

Figure 6-A shows the Pindell \& Dewey pre-opening fit (1982), which includes intraplate deformation in the Benue Trough area. They started from the Aptian pole of Rabinowitz \& LaBrecque (1979) (plain limits in Figure 5-B), and deformed Africa between Valanginian and Late Aptian with the pole $19^{\circ} \mathrm{N}, 2^{\circ} \mathrm{E},\left(\alpha=-8^{\circ}\right)$ : West Africa is fixed to South Africa in order to keep the Aptian adjustment in the Equatorial Atlantic Ocean. The movement of the south- 
eastern African block induces a compressive motion in the Benue Trough, increasing eastwards, which is incompatible with the geological data (no compression on field, Unternehr et al., 1988). Furthermore, an overlap still remains between the Demerara and Guinean plateaus and between the two hinge lines in the Central Segment. Finally, the southernmost Atlantic complete fit is not achieved (Figure 6-A). Following the African option, Guiraud \& Maurin (1992) proposed a more complex kinematic model with three African blocks, including the history of the Atlantic, Indian and Tethys oceans but, as already noted by Unternehr et al. (1988), the movements induced by African intraplate deformations are not sufficient to close the South Atlantic Ocean (Moulin, 2003).

Meanwhile, in 1984, Curie explored the hypothesis of an intraplate discontinuity in South America (Figure 6-B). The introduction of a discontinuity in the area between the Rio Grande Rise to Cochabamba Santa Cruz bend, in the Bolivian Andes, allowed Curie to close the southern part of the South Atlantic independently of the adjustment of the equatorial margins and of the central segment. This reconstruction implies a large compression west of the Paraná Basin. Due to the presence of the Paraná volcanism (Serra Geral Fm., with Early Cretaceous ages, (133 Ma, Renne et al., 1992)), the direct and quantifiable observations for such an intraplate deformation are difficult along the Southeastern Brazilian sedimentary basins. However, Eyles \& Eyles (1993) highlighted the existence of a dextral strike-slip movement of $150 \mathrm{~km}$ in the Paleozoic rocks that form depocenters in the northern part of the Paraná basin, based on a sub-surface study. The offsets of the Upper Paleozoic glaciogenic infill, the Paraná - Etendeka volcanic episodes both around 133 My (Renne et al., 1992, Marzoli et al., 1999a), just before the opening of the ocean, the formation of a major barrier for salt deposition just after the rifting, and the later emplacement of the Rio Grande Rise and Walvis Ridges associated with a thermal anomaly (Mascle \& Renard, 1976), plead in favour of a major discontinuity at this problematic junction and are used by several authors (Unternehr et al., 1988; Conceição et al., 1988, Nürnberg \& Müller, 1991; Lawver et al., 1999; Macdonald et al, 2003; Schettino \& Scotese, 2005; König \& Jokat, 2006; Eagles, 2006). Unternehr et al. (1988) proposed that this zone, which is located and limited in extension through the plates is a discontinuity of second order, as defined by Olivet et al. (1984) and Olivet (1996), played a major role in the development of the Sout Atlantic Ocean. Nevertheless, the American option alone induces a strike slip movement of more than 400 $\mathrm{km}$ in this area (Figure 6-A and Unternehr et al., 1988), which led to combining options (intraplate deformation in both South America and Africa plates).

In 1991, Nürnberg \& Müller published a new global model based on Satellite Altimetry data, bathymetric charts and compilation of magnetic anomaly picks, which remains the basic reference for oceanic crust ages. Following the suggestion of Curie (1984) and Unternehr et al. (1988), their pre-opening reconstruction integrates both African (two blocks) and South American (four blocks) continental intraplate deformations (Figure 7). They started with a initial reconstruction in order to match the Demerara and Guinea plateaus as well as the Equatorial Fracture zones defined from Geosat and Seasat altimetry data, bathymetry and magnetic data. In this study, we defined the limits of these two plateaus in more detail, using new high resolution data (Gouyet, 1988, Gebco97, 1mn x 1mn satellite-derived free air gravity data, Guyaplac seismic profiles). With these new limits, a $150 \mathrm{~km}$ large gap remains between these two conjugate plateaus, which implies a huge compression. Note that a $150 \mathrm{~km}$ compression is of the same order of magnitude as that which induced the Pyrenées. Such a deformation has never been seen on seismic profiles or represented in paleogeographic maps of the Equatorial Atlantic Ocean (Matos, 2000). Moreover, the conjugate Kandi and Sobral lineaments show an offset of $140 \mathrm{~km}$, which disqualifies the reconstruction in the Equatorial segment. In the Central segment, the Rio Grande Fracture Zone conjugate segments have an offset of around $100 \mathrm{~km}$ and the salt basin limits overlap the conjugate continents. Hinge lines also overlap in the Tucano Basin (JRT Basin). In the Austral segment, the conjugate LMA system alternatively presents large gaps and overlaps. Thus, the Nürnberg \& Müller model was indeed an important stage in the definition of the South Atlantic Ocean fit and its evolution, including several intraplate deformations both in 
South America and Africa, but it does not fit the new, updated geological and geophysical data set.

The reconstruction of Lawver et al., 1999 (Figure 8A), which was an issue of the international PLATES project (University of Texas: http://www.ig.utexas.edu/research/projects/plates) differs from that of Nürnberg \& Müller (1991) only in the Austral segment: the induced intraplate deformations are coherent with geology, but the reconstruction does not take into account the symmetry of the magnetic anomalies: the conjugate LMA system presents a $150 \mathrm{~km}$ large overlap. Northwards, the Rio Grande Fracture Zone System shows a $100 \mathrm{~km}$ large offset. Moreover, Lawver and co-authors used poles similar to those of Nürnberg \& Müller (1991) in the Central and Equatorial segments and their reconstruction present the same misfits that disqualify it. This problem is recurrent in all most recent reconstructions from 2003-2006, which are based on the model of Nürnberg \& Müller (1991) for the Equatorial and Central Segments (MacDonald et al., 2003; Eagles, 2006; Konïg \& Jokat, 2006).

The model of König \& Jokat (2006), for instance, results from a new set of rotations, issued from new published high-resolution aeromagnetic data from the eastern Weddell Sea (Figure 8-C). It describes the early opening of the Weddell Sea between South America and Antarctica and the Mesozoic break-up of Gondwana, at the Jurassic Quiet Zone (JQZ) stage, and is supposed to be the tightest initial reconstruction. In addition to the inherent problems with the poles of Nürnberg \& Müller in the Equatorial and Central segment, this reconstruction presents a certain number of misfits: $450 \mathrm{~km}$-dextral strike slip motion along the Gastre System Faults associated with $180 \mathrm{~km}$ of extension, $130 \mathrm{~km}$-extension in the Colorado basin, and more than $250 \mathrm{~km}$ overlap of the LMA system and a $300 \mathrm{~km}$ large offset in the Falkland Fracture zone system.

The model of Eagles (2006) supposes a northwards propagation of the intraplate deformation inside South America. We only found the pole between the southern parts of South America and Africa in the paper's tables and we assume that Eagles used Nürnberg \& Müller's pole for the rest of the ocean. Anyway, this pole has dramatic misfits in the Austral segment with the 300-450 km large overlap of the LMA (Figure 8-D).

The last published model (Torsvik et al., submitted October 2008, accepted Fev. 2009) is based on the Nürnberg \& Müller (1991) reconstruction in the central segment, which has large overlaps and misfits (Aslanian et al., 2009) and gives a bad framework for the rest of the system (Aslanian \& Moulin, submitted). It also used in the Austral Segment the magnetic data set given by Müller et al., (1997) without considering the latest published magnetic data sets (Aslanian \& Moulin, submitted).

The model of Schettino \& Scotese (2005) does not use the model of Nürnberg \& Müller (1991) for the Equatorial and Central Segments and is based on synthetic apparent polar wander (APW) paths for major continents (Figure 8-B). We will only discuss in detail the reconstruction of the South Atlantic Ocean. The match of Demerara and Guinean conjugate plateaus is relatively good, but this reconstruction present an overlap of the Sao Luis and West African Precambrian shields, from $140 \mathrm{~km}$ in the west part to $280 \mathrm{~km}$ in the Niger area. In the Central segment, the Aptian salt basin is characterized by critical overlapping on continental regions at conjugate margins. In the Austral segment, this reconstruction also presents an overlap of more than $100 \mathrm{~km}$ wide of the LMA system.

The existence of several intraplate deformations on both Africa and South America plates is now well accepted, but none of these reconstructions presents a fit in agreement with both geological and geophysical data.

\section{Towards a new model: a 13 piece jigsaw puzzle}

\subsection{Step 1: the Equatorial Segment}

Following Nürnberg \& Müller's approach, we began with the Equatorial segment. Despite the lack of magnetic lineaments, we will show that the tectonic evolution of this segment is relatively well constrained by geological structures. 
We first took into account the fit at Chron C34 (83 Ma), which is a quite well defined period due to the presence of well-marked fractures zones and clear magnetic anomalies (just after the Quiet Cretaceous Magnetic period).

Four different models exist for this period: Cande et al., (1988), Nürnberg \& Müller (1991), Campan (1995) and Müller et al. 1999 (which was integrated in the PLATES compilation program, Gahagan, L., pers. comm.). Their differences are very slight, depending on the weight given to the magnetic data or the fractures zones. We chose the reconstruction of Campan (1995), which is very close to the reconstruction of Müller et al. (1999): it constitutes a compromise between the adjustment of the magnetic anomalies and the zones of fractures and presents the best fracture zone adjustment in the Equatorial Atlantic Ocean (whereas the adjustment of the magnetic anomalies and the fracture zones in the Austral segment is slightly of lesser quality) as shown on Figure 9. We have overprinted on this figure the small circles described by the intermediate pole 105Ma-C34 of Campan (1995) and extrapolated them to the fit (black dotted arcs). The perfect correspondence between those small circles and the Equatorial fracture system implies that fracture zones do not change direction between the anomaly C34 and the fit, and have the same Eulerian Pole throughout this period. We can therefore use these fracture zones like rails, using the 105Ma-C34 of Campan, to move plates until we match the American and African conjugate structures (margins, lineaments, cratons, plateaus).

On Figure 10, the South American Plate has been rotated along these guides, in order to match the Demerara and Guinean plateaus $\left(41.1^{\circ} \mathrm{N}, 27.78^{\circ} \mathrm{W}, \alpha=17.66^{\circ}\right)$. The position of 200 and 2000m-isobaths extracted from the Gebco chart (Gebco97), which are supposed to correspond respectively to the platform and the ocean/continent boundary (Bullard et al., 1965), both present a good adjustment except for the Amazon and Niger deltas where the Tertiary sedimentation is characterized by extremely high rates in both regions. The Ilha de Santana Plateform, in the northern region, corresponds to a concave inflection of the African Coast. A gap persists east of the Sobral-Kandi system, which is also marked on the African side, in the prolongation of the Benue Trough, by a negative gravity anomaly (see also Figure 9). This indicates the existence of a basin associated with the continental rift before the opening with the Atlantic Equatorial (Ponte \& Asmus, 1976; Gouyet, 1988). Note also the parallelism of the coastlines that tends to prove the absence of deformation in the Guyana and West African Precambrian shields. Lastly, the adjustment of the Demerara and Guinean plateaus as well as the alignment of the Kandi and Sobral lineaments are very good and give good longitudinal control: no further movement can be applied to this area. This fit thus presents the Equatorial segment in its tightest possible position, which therefore represents an incompressible zone.

The final total Eulerian pole is situated at $54,27^{\circ} \mathrm{N}, 34,98^{\circ} \mathrm{W}\left(\alpha=50,43^{\circ}\right)$. Note that this Eulerian pole is very close to the Aptian Eulerian pole of Rabinowitz \& LaBrecque (1979) $\left(55,1^{\circ} \mathrm{N}, 35,7^{\circ} \mathrm{W}, \alpha=50.9^{\circ}\right)$, which was used by Curie for her fit $\left(55,1^{\circ} \mathrm{N}, 35,7^{\circ} \mathrm{W}, \alpha=49,4^{\circ}\right)$.

\subsection{Step 2: the Central and Austral Segments and intraplate deformation}

The consequences of this initial fit of the Equatorial Atlantic Ocean on the complete South America / Africa reconstruction is shown on Figure 11. A number of fracture zone misfits and a huge oceanic gap in the Austral Segment are observed. South of the Rio Grande Fracture Zone, conjugate MO magnetic anomalies are separated by 170 to $280 \mathrm{~km}$. In the Central Segment nevertheless, the external limits of the conjugate Aptian salt layers (the "compressive Brazilian and African salt front"), which fringe the first true oceanic crust, are face to face.

As already noticed by Unternehr et al. (1988) and Nürnberg \& Müller (1991), the closing of the entire South Atlantic Ocean absolutely requires to take into account both African and South American intraplate deformations.

We therefore compiled all published geological and geophysical information about Cretaceous continental deformation on the South American and African plates in all 
deformation style (extension, compression, transpression, transtension, sinistral or dextral shear) and all published quantity of deformation. As suggested by Guiraud \& Maurin (1992), all the Cretaceous structures that force the intraplate deformation are localised on PanAfrican sutures. This observation corroborates a more detailed interpretation of the geological data (Martin et al., 1981). As Olivet et al., (1984) quote: deformations are generally concentrated on pre-existing crustal zones of weakness (the "second-order boundary") and form more or less continuous bands which are defined like limits of second order blocks relatively undeformed. The description below follows the model of Guiraud \& Maurin, (1992) in Africa, and the assumptions of Curie (1984), Szatmari et al., (1985), Unternehr et al. (1988), Conceição et al., 1988, Milani \& Davidson (1988), Nürnberg \& Müller (1991) and Fairhead \& Maus (2003) in South America.

\subsubsection{African intraplate deformation}

Most of the troughs and faults are situated within the mobile zones of the Panafrican fold belts (Figure 1), and following Guiraud \& Maurin (1992), we separated the Cretaceous Africa plate into three main blocks: West Africa block, Nubian block, and Austral block to which we added the additional microplate of Benue (Figure 12). As already noticed, the boundaries between these blocks form more or less continuous bands of deformation that we represented by simple lines on figures for graphical purposes, but the deformation is spread laterally on both sides of this line, within the suture belt.

Along these boundaries, the type and the magnitude of the deformation are given either by geological or geophysical studies. The geophysical estimations give maximum deformation (Fairhead, 1988) but as they are based on a simple 2D-gravimetric model, they must be considered with precaution.

The Benue microplate is bounded northwards by the Benue Trough, northeastwards by the Bongor rift and southwards by the Precambrian Ngaoundéré lineament, which shows a small reactivation at Lower Cretaceous (Cornacchia \& Dars, 1983). The Benue Trough is described as a sinistral strike-slip fault with some evidence of extension: $85 \mathrm{~km}$ for Fairhead (1988), between 10 and $50 \mathrm{~km}$ for Unternehr et al., (1988) and between 60 and $70 \mathrm{~km}$, with 20 to $30 \mathrm{~km}$ of sinistral strike-slip movement, for Nürnberg \& Müller (1991); both estimations are based on kinematic studies. In the North-East limit, Guiraud \& Maurin (1992) describe the Bongor Rift as a NNW-SSE-trending extensional Trough dated from Neocomian to Barremian. The order of magnitude of the movement in the rift is unknown. It is prolonged northwards by the Tchad shear zone. The Ngaoundéré lineament is a dextral Aptian strikeslip fault, which is the prolongation of the Central African shear zone described by Cornacchia \& Dars (1983), Cornacchia (1986) and Benkhelil (1988) with a 40-50 km dextral strike-slip zone.

In the northern prolongation of the Benue Trough, the Tenere Basin, the Amguid-Gassi TouilAlgeria and $10^{\circ} \mathrm{E}$ lineaments (Boudjema, 1987; in Guiraud \& Maurin, 1992; Guiraud et al., 2000) constitute the boundary between the West African and Nubian blocks. Fairhead (1988) estimates the NE-SW-trending extension in the Tenere Basin to be about $60 \mathrm{~km}$. Further north, sinistral strike-slip movements of the Amguid-Gassi Touil-Algeria and $10^{\circ} \mathrm{E}$ lineaments are poorly known. Boudjema (1987), in Guiraud \& Maurin (1992) described a transpressive Cretaceous deformation in the El Boid - Gassi Touil basins.

The boundary between Nubian and Austral blocks is composed of the Central African shear zone that ends eastwards in the Sudan Rift. Cornacchia \& Dars (1983), followed by Cornacchia (1986), Benkhelil (1988) and Fairhead (1988) indicate a 40-50km sinistral strikeslip deformation in the Central African shear zone, with a small extensive component (Fairhead, 1988, Genik et al., 1992, Guiraud \& Maurin, 1992). In the Sudan rift, composed of Muglad, Blue Nile, White Nile and Melut basins, Fairhead (1988) estimates the extensive global movement at about $50 \mathrm{~km}$, whilst Jorgensen \& Bosworth (1988) minimize it to $14 \mathrm{~km}$. The SE termination of the rift is poorly defined, but the Cretaceous rift of Anza (Bosworth \& Morley, 1994) may correspond to the final termination of the plate limits. 
Guiraud \& Maurin (1992) and Maurin \& Guiraud (1993) described two phases of deformation, emphasizing the role of Tethyan margin evolution on the Nubian plate movement. The first phase of deformation occurred from Valanginian to lower Aptian, with transtension in the south of Tchad, north of Cameroon and the High Benue Trough, and sinistral movement along the Amguid-Gassi Touil-Algeria fault system. The Nubian block moved northwards, relative to the west African block, in relation to the opening of the Indian Ocean (the closing of Tethys Ocean), whilst the Austral block moved northeastwards, in relation to the opening of the South Atlantic Ocean (Guiraud \& Maurin, 1992). A change in the direction of the Nubian plate movement from North to North-East occurred in the middle Aptian, related to a sharp activation of the sinistral Maghrebian-South Anatolian shear zone and acceleration of the opening of the East Mediterranean Basin; the second phase corresponding to the opening of the Equatorial Atlantic Ocean with a dextral movement along the fractures zones, an extension in the basins of Ténéré, Kenya, Sudan and Syrte and a transtension in the Benue basin and Central African shear zone. No reversal movement is described between these two phases. The north-eastward movements of the Nubian and Austral African blocks during the last stage are given by a pole close to that defined independently by Klitgord \& Schouten (1986) in the Central Atlantic Ocean, with different rotation angles.

\subsubsection{South America Intraplate Deformation}

In South America, we compiled the studies of Curie (1984), Szatmari et al., (1985), Unternehr et al., (1988), Conceição et al., 1988, Milani \& Davison (1988), Nürnberg \& Müller (1991), Fairhead \& Maus, (2003), Jacques (2003a, 2003b), Eagles (2006) and divided the plate into 9 pieces: Guyana, NE-Brazil, Tucano, São Francisco, Santos, Rio de la Plata, Argentina, Salado and Patagonia blocks (Figure 13).

We separated the South America plate of Nürnberg \& Müller (1991) into 5 additional blocks according to the work of Szatmari et al., (1985), Milani \& Davison (1988) and Fairhead \& Maus, (2003). The north-east block integrates the Potiguar and Araripe Cretaceous basins and is delimited westwards by the Precambrian Sobral lineament and southwards by the Tucano-Recôncavo- Jatobá basins that delimit the Tucano block described by Szatmari et al., (1985) and Milani \& Davison (1988) and Szatmari \& Milani (1999). In this area, Fairhead \& Maus (2003) described possible sinistral strike-slip Aptian movement. Mohriak \& Rosendahl (2003) suggest that the offshore area (east of the Tucano basin) was characterized by strike-slip movements during the early stages of drifting.

We also separated the São Francisco and Santos blocks from the Guyana block along a boundary including the Transbrasiliano and the Sobral lineaments for kinematic reasons: the opening of the Santos basin predates the opening of the structures in the São Francisco block, as we will show later. The position of the Transbrasiliano lineament is difficult to know precisely but can be drawn using the terrestrial geophysical data from Fairhead \& Maus (2003). It has been active since Panafrican times and is still active (large seismic activity recorded in 1957, Sykes, 1978). The western end of this limit is unknown and we prolonged it into the Andean Cordillera virgation. The boundary between the São Francisco and the Santos blocks is unknown and we arbitrarily chose a parallel to the Santos and Rio de la Plata limit, which follow marked NW lineaments expressed by Mesozoic dikes.

The boundary between the Santos block and the Rio de la Plata block corresponds to an extensional-dextral shear zone described by Curie (1984), Conceição et al. (1988), Unternehr et al. (1988) and Nürnberg \& Müller (1991). The estimated movement varies from 20-30 km dextral and 60-70 km extensive movement for Nürnberg \& Müller (1991) to $100 \mathrm{~km}$ extensive movement according to Sibuet et al. (1984), or hundreds of $\mathrm{km}$ of dextral shear movement according to Unternehr et al. (1988) (more than $350 \mathrm{~km}$ with $150 \mathrm{~km}$ extension), This limit is hidden by the huge Early Cretaceous Serra Geral volcanism of Paraná Basin, but Zalán et al., 1990 described in a regional structural framework, a serie of linear tectonic faults and Eyles \& Eyles (1993) inferred, from a sub-surface study of the upper Paleozoic glaciogenic infill, the possible existence of a $150 \mathrm{~km}$ dextral strike-slip movement in the 
Paraná Basin. Indirect methods (like gravity or magnetism) could help to detail this network of faults zone. These discontinuities drawn on the figures must be regarded as symbolic areas that indicate where the deformation related to each rifting/drifting event should be found.

According to Conceição et al. (1988) and Nürnberg \& Müller (1991), the Salado block is bounded by the Salado and Colorado basins. The geological investigations in these two basins describe an extension of about $20-25 \mathrm{~km}$, associated to $20-30 \mathrm{~km}$ of shear movement (Zambrano et al., 1970; Urien \& Zambrano, 1973). Franke et al., 2006, using seismic reflection and refraction data, compared the Colorado Basin to a "pull-apart" basin with extension and strike-slip movement. This block separates the Rio de la Plata block in the north from the Argentina block in the south.

Further south, the boundary between the Argentina and Patagonia blocks is located in the Gastre Fault system where Jacques (2003a; 2003b), following Rapela et al. (1991) and Rapela \& Pankhurst (1992), described a dextral movement along the northern border of the San Jorge embayment. The implication of this great system on the formation of the Falklands is beyond our subject and will not be discussed in this paper (we will consider the Patagonia block as attached to the Argentina block).

According to Unternehr (1988), Milani \& Davidson, (1988), Nürnberg \& Müller (1991), Fairhead \& Maus (2003), there is only a single phase of deformation during the breakup of South America, which occurred in Neocomian time. These deformations occurred during the initial phase of the opening of the Austral segment and were almost completed before the Albian (Unternehr et al., 1988). However, there are several works which report magmatism and tectonic activity involving extensional and compressional events in the South American eastern margin during the Cretaceous and Tertiary (Gondcalves et al., 1993; Mohriak, 2003; Zalán \& Oliveira, 2005).

\subsubsection{Precision}

Information about intraplate deformations is therefore very disparate and their quantification, when available, can vary significantly. The question of their use and efficiency to constrain models naturally arises. We will show through an example that even qualitative information can be a drastic constraint in precise kinematic reconstructions.

Figure 14 represents Africa with the four Cretaceous sub-plates in their present day positions (black limits). Red and green limits represent two possible rotations of the Nubian block, with the quantified deformation that they produce at the blocks boundaries (again, the deformations produced within a block are symbolised on figures by simple lines at the frontiers of the blocks). The insert in figure 14 is a zoom of the Benue and Nubian blocks limit. The figure shows that a small difference in movement (less than $40 \mathrm{~km}$ on average) on this limit, due to the rotation of the plate, implies large qualitative differences in the Sudan Rift and even opposite deformation in the Amguid-Gassi Touil-Algeria and $10^{\circ} \mathrm{E}$ lineaments system. A small difference in position of one limit can have drastic consequences on the distant boundaries of the plates. So, even a qualitative description of intra-plate deformation can be a strong constraint for kinematic reconstruction (with a precision of about $40 \mathrm{~km}$ in this case). Note that this example involves only the movement of the Nubian sub-plate. The precision of reconstruction will increase with the number of blocks used: as the number of the blocks increases, the more difficult it is to respect all constraints of deformation but also, the number of satisfactory solutions strongly decreases. We employed all this data using a trialerror method with the PLACA free share software (Matias et al., 2005).

Even if some boundaries show signs of an absence of deformation (as the perfect parallelism of the coastlines of the Guyana and West African shields), some diffuse deformation could also occur within some blocks. Fidalgo (2001) showed that this type of deformation cannot be excluded. Deformation does not concentrate exclusively at the borders of plates, but occurs in a more diffuse way on the oceanic domain and also in continental sedimentary basins. According to Fidalgo (2001), the order of magnitude of this deformation is 
approximately $50 \mathrm{~km}$. This will be taken into account when trying to find the tightest fit for the South Atlantic Ocean.

\subsection{Initial fit}

Figure 15 and zooms on Figures 16 and 17 present our tightest initial fit (ante chron M7). The Eulerian poles are listed in Table 2. The fit has been processed independently in the Central and Austral Segments.

According to Guiraud \& Maurin (1992), we rotated the Austral block with the pole used by Fairhead (1988) and the Nubian block using the same pole. These authors did not give the angles for the rotation. In order to be coherent with the geological and geophysical intraplate information, we applied an angle of $1,5^{\circ}$ for the Austral and an angle of $-2.36^{\circ}$ for the Nubian block (with respect to the fixed West African block). In order to minimize the extension in the Bongor rift, the Benue microplate was also moved. This reconstruction implies $30 \mathrm{~km}$ of compression in Tunisia, $110 \mathrm{~km}$ of sinistral strike-slip movement along the $10^{\circ} \mathrm{E}$ lineament, $80 \mathrm{~km}$ of extension in the rift of Niger, $70 \mathrm{~km}$ of dextral strike-slip movement along Central African shear zone and $72 \mathrm{~km}$ of extension in the rift of Sudan (Figure 15).

In order to better match the Patos/Ngaoundere, Pernambuco/Sanaga and Ascension Fracture zone systems and to take into account the presence of the Araripe, Potiguar and offshore basins, we slightly rotated the NE Brazil microplate. Following Szatmari et al., (1985), Milani \& Davison (1988) and Szatmari \& Milani (1999), we also moved clockwise the Tucano microplate. The São Francisco block was moved in order to maintain the coherence of the whole system and to tighten the central segment. These movements infer $10-20 \mathrm{~km}$ of extension in the Araripe \& Potiguar basins, $50-60 \mathrm{~km}$ of extension in the Tucano basin and $60 \mathrm{~km}$ of dextral strike slip motion along the Sobral- Transbrasiliano system (Figure 15 \& 16). Note that in this tightest position, a $280 \mathrm{~km}$ wide gap remains between the two conjugate African and Brazilian hinge lines (in blue in Figure 16; Aslanian et al., 2009). The salt basin could not have formed at this stage because the boundaries show critical misfits in the southern Brazilian province, extending onto Africa.

The position of the three southern Rio de la Plata, Salado and Argentina blocks is given by the fit of the conjugate LMA, the fit of the Rio Grande and Agulhas-Falkland Fracture zones (Figure 17). Some gaps and overlaps still remain usually less than $50 \mathrm{~km}$ large, which is the order of magnitude of the diffuse deformation. These overlaps may be due to the presence of the intraplate limit (as in the case of the intraplate limit between the two Rio de la Plata and Salado sub-blocks at $30^{\circ}$ ), the sparsity of the magnetic data in some areas (as for the southern $70 \mathrm{~km}$ gap) or a smaller segmentation (as proposed by Jacques, 2003b and Franke et al., 2007 for the southern $70 \mathrm{~km}$ overlap). This reconstruction implies $50-70 \mathrm{~km}$ of extension distributed between the Salado basin and the Andean Cordillera, a $60 \mathrm{~km}$ strikeslip movement in the Salado Basin and $50 \mathrm{~km}$ of extension in the Colorado Basin.

These two fits, in the Central and Austral segments, imply a huge deformation in the Paraná area (about $350 \mathrm{~km}$ of strike slip movement and $115 \mathrm{~km}$ of extension) that has never been observed (although the presence of the large lava flow may hinder such observations). The only information comes from Eyles \& Eyles (1993) who quote a $150 \mathrm{~km}$ dextral strike-slip movement in the Paraná Basin. In order to match this value, we therefore dissociated the Santos block from the São Francisco block so that the deformation can be distributed between Paraná basin and the Ribeira Belt, which corresponds to metasedimentary rocks deformed during the Brasiliano orogeny (Heilbron et al., 2000). This movement, confirmed by the presence of the M3 or M0 magnetic anomaly (Cande \& Rabinowitz, 1978) and the presence of a fossil ridge on a seismic profile of the Santos basin (Moulin et al., 2006) implies an eastward ridge jump as already suggested by Pontes \& Asmus (1976) and Kumar \& Gambôa (1979). The reconstruction allows 1) to align the coastlines on both sides of Rio de Janeiro, 2) to obtain good parallelism of the conjugate coastlines in the whole central segment and 3) to provide a more coherent and reasonable deformation in the Paraná (150 $\mathrm{km}$ dextral strike slip motion associated with $70 \mathrm{~km}$ of extension). In the Ribeira belt, this configuration presents an extension of $60 \mathrm{~km}$ which is also coherent with geological and 
geochemical studies (Figure 18): Tello Saenz et al. (2003), Guedes et al., (2005), Hackspacher et al. (2004) and Bueno (2004) show evidence of NE-SW-trending dike activities directly related to the breakup of the South Atlantic Ocean. The age of these dike activities and tectonic reactivation ranges from 120Ma (Tello Saenz et al., 2003) to 135137Ma (Guedes et al., 2005). Moreover, Guedes et al. (2005) show that this group of dikes is correlated with the well-defined magmatic event of the Paraná basin lavas and NW-SE Ponta Grossa dike swarm (127-137 Ma; Mantovani et al., 1985; Hawkesworth et al., 1992; Renne et al., 1992; Turner et al., 1994). It is worth noting that NW-NNW-trending orientation of these dikes, parallel to local fractures and faults, in the Ribeira Belt (Guedes et al., 2005) differs from the ENE-trending orientation of the Rio de Janeiro dike swarm, which are parallel to the Precambrian structures, in the north, and to the N-S orientation of the Pelotas dike swarm (Renne et al., 1996) in the south.

From a geodynamic point of view, we can say that the Santos Block plays a role of kinematic buffer, a kind of relay zone, between the movements that created the northern Campos and Espirito Santo basins, which are characterized by the presence of an Aptian salt layer and huge oil reservoirs, and the southern volcanic basins of the South Atlantic Ocean. However, we would like to emphasize again that the discontinuities in the Paraná Basin and in the São Francisco Basin must be regarded as symbolic: in these areas the deformation may be dispersed throughout a larger area, diluted among several fault zones displaying minor reactivations, that, compiled, should account for the amounts of extension and compression described in the text.

\subsection{Chron M7 ( $132 \mathrm{Ma}$ after Gradstein et al., 2004)}

No kinematic reconstruction has been published for this time. This stage is marked by the presence of M7 magnetic anomalies in the southern part of the Austral Segment (Figures 3 \& 4 ), implying movements within the southern plates system. Between the initial fit and chron M7, the Argentina and Salado blocks moved westwards, relative to the West African block. We therefore linked them and moved them together after Chron M7.

According to Guiraud \& Maurin (1992) and Maurin \& Guiraud (1993), the first phase of deformation in Africa occurred from Valanginian to Early Aptian. Nevertheless, the movement of the Austral African block from the fit to the present day position (dotted lines on Figures 19 to 22) increases the deformation in the Paraná Basin, due to the resulting movement of the South American sub-plates (in order to fit the magnetic anomalies). We infer that most of the movement of the Austral and Nubian African blocks for the first stage occurred between chrons M4 and M2, during the Barremian, in order to maintain a coherent evolution of the deformation in Paraná and Santos basins. Throughout our reconstruction, we will keep the African blocks in the same situation as in the initial fit, until chron M4. That does not exclude very small movements during the Neocomian time.

Figure 19 presents our reconstruction at Chron M7. The blocks involved in the central segment do not move and stay in the same position. The movements of the southern South American blocks imply a strike-slip movement in the Punta del Este - Salado basins and in the Andean Cordillera (Salado-Argentine and Rio de la Plata blocks boundary). The studies of Zambrano et al., 1970; Urien \& Zambrano, 1973; Jacques, 2003b; Franke et al., 2006 confirm this kind of movement.

\subsection{Chron M4 ( $130 \mathrm{Ma}$ after Gradstein et al., 2004)}

Four kinematic models have been published for this period: Curie (1984) considers chron M4 as the initial fit, Nürnberg \& Müller (1991) and Lawver et al., (1999) concentrate the deformation at this stage in the Paraná Basin and Konig \& Jokat (2006) use the nondeformed reconstruction of Martin et al., (1982). All these models produce unacceptable deformations (400 km dextral motion in the Paraná basin or $100 \mathrm{~km}$ of compression between the conjugate Demerara and Guinean plateaus) and/or a large overlap on the conjugate 
magnetic anomalies. This points out the need for a new and constrained kinematic reconstruction.

Between M7 and M4, the Rio de la Plata plate started to move westwards and allowed the beginning of the opening in the northern part of the Austral segment and the recording of the magnetic anomalies.

Figure 20-A presents our reconstruction at Chron M4. In the Austral segment, this reconstruction tries to produce the best reasonable fit of the magnetic anomaly, fracture zones systems and conjugate structures. The small circles given by this pole are parallel to the Rio Grande and Falkland fracture zones. This reconstruction presents a pretty good fit of the M4 anomaly in the entire Southern Segment, with misfits below $30 \mathrm{~km}$ (Figure 20-B). These misfits may be linked to diffuse deformation or to varying quality of magnetic data on both sides. The misfit of the Rio Grande Fracture Zone system is of the order of magnitude of diffuse deformation and can be explained by deformation induced by the presence of the volcanic rocks in the Paraná Province.

The inferred deformations are a dextral strike-slip movement of $60 \mathrm{~km}$ associated with $50 \mathrm{~km}$ of extension in the Paraná basin and $60 \mathrm{~km}$ of extension associated with $100 \mathrm{~km}$ of strike slip motion in the north of the Santos plate.

\subsection{Chron M2 (127.5 Ma after Gradstein et al., 2004)}

Despite the fact that chron M2 seems to be the most continuous and well-defined anomaly in the Austral Segment, very few precise studies exist: König \& Jokat (2006), in their study of the general evolution of the Mesozoic break-up of the Weddell Sea, propose one of the rare reconstructions at Chron M2. As we already quote, they used similar poles to Nürnberg \& Müller (1991) in the Central and Equatorial segments and their reconstruction presents the same misfits. We consequently propose here a new reconstruction.

Between M4 and M2, the Rio de la Plata block and the Argentine-Salado blocks were connected and these three blocks moved together. The Santos plate started to move slowly westwards, following the movement of the southern part of South America. In the Austral segment, the movements are calculated in order to obtain the best fit of the magnetic anomalies, fracture zone systems and conjugate structures (Figure 21). On the African plate, the Nubian block moved northwards and the Austral block northeastwards. This last small movement may have lasted until chron $\mathrm{MO}$ or until the end of the Aptian. It could also be distributed from M4 to Aptian, but the main movement seems to have occurred between M4 and $\mathrm{M} 2$ as this enable to minimize the deformation in Paraná and Santos areas.

Figure 21 shows our reconstruction at chron M2. Note the nearly perfect fit of the conjugate isochrons M2 (Figure 21-B): the main misfits probably arise from the varying quality of magnetic data. The offset of the Rio Grande and Falkland - Agulhas Fracture Zone system is about $20 \mathrm{~km}$. The small circles given by the Eulerian poles are parallel to these fracture zones. This reconstruction only creates $50 \mathrm{~km}$ of extension in the Paraná basin and $30 \mathrm{~km}$ of extension in the northern limit of the Santos block.

\subsection{Chron MO (125Ma after Gradstein et al., 2004)}

Five main reconstructions have already been published: Rabinowitz and LaBrecque (1979), Nürnberg \& Müller (1991), Schettino \& Scotese (2005), Konig \& Jokat (2006) based on Martin et al., (1982) and Eagles (2006).

Rabinowitz and LaBrecque (1979) did not integrate intraplate deformation and propose an unsatisfactory fit of the southern fracture zones (Rio Grande \& Agulhas-Falkland). Nürnberg \& Müller (1991) deform only the African plate at this stage and present a better fit but the main problems in the Equatorial segment remain. Following Nürnberg \& Müller (1991), Schettino \& Scotese (2005) deform only the African plate. This reconstruction shows an unsatisfactory fit of magnetic anomalies and creates a significant overlap in the Equatorial Segment. The reconstruction of Konig \& Jokat (2006) comes from the reconstruction of Martin et al. (1982). They proposed a very good fit of magnetic anomalies (close to the pole 
proposed by this study), but they did not integrate intraplate deformation, implying a large overlap in the Equatorial Segment. Eagles (2006) reconstruction presents a good fit of magnetic anomalies but has drastic consequences in the Equatorial Ocean and the Recôncavo-Tucano-Jatobá rift.

According to Guiraud \& Maurin (1992), M0 marked the end of the first deformation in Africa, which occurred from Valanginian to Aptian. Due to the increase in the deformation in the Paraná Basin induced by the movement of African blocks, we infer that most of the movements of the Austral and Nubian African blocks occurred between chrons M4 and M2. According to Guiraud \& Maurin (1992), the Nubian block moves northwards, whilst the Austral block moves north-eastwards.

In South America, except for the Santos Block, which continues its slow westwards movement, the northern part (Tucano-NE Brazil-Guyana-São Francisco blocks) does not move. The Argentina-Salado-Rio de la Plata blocks move together and allow a very good fit of the MO conjugate anomalies. The small circles given by the Eulerian pole are parallel to the Rio Grande and Falkland fracture zones.

Figure 22 presents our $\mathrm{MO}$ reconstruction. At this time, there is still a $40 \mathrm{~km}$ deformation in the Paraná basin and $30 \mathrm{~km}$ in the northern limit of the Santos block.

\subsection{Aptian-Albian (112 Ma)}

The Aptian-Albian Boundary corresponds to the end of the salt deposition and the break-up within both the central and Equatorial segments.

Rabinowitz \& LaBrecque (1979) proposed a reconstruction at the end of the salt deposition, which shows an overlap in the Demerara-Guinea area and an unsatisfactory fit of the salt boundaries (a gap of $100 \mathrm{~km}$ in the Sergipe-Gabon Basins). In their model, this reconstruction followed a compressive stage in the Equatorial Segment, due to the opening of the South Atlantic Ocean and the rigid plate hypothesis they assumed.

Between Chron MO and this time, the African blocks movement changed considerably. Meanwhile the Austral block slowly stopped its rotation to reach its present day position with respect to the West African block, the Nubian Block rotated through the north-east, in agreement with the observations of Guiraud \& Maurin (1992). At Aptian-Albian Boundary, the Africa plate is no longer deformed. In the South American plate, movements between Tucano, NE Brazil and São Francisco blocks took place after MO and ceased at AptianAlbian Boundary. Our reconstruction is presented in Figure 23 and is slightly tighter than the reconstruction of Unternehr et al., (1988). This reconstruction presents a gap of $80 \mathrm{~km}$ between the salt boundaries in the Sergipe-Gabon basins associated with $40 \mathrm{~km}$ of overlap in the Namibe Basin, slightly smaller than in the Unternehr et al., (1988) and in Rabinowtiz \& LaBrecque (1979). However we could not further minimize these misfits by block movements without irrational deformation. We suggest that they are probably the result of badly defined salt limits in the northern part of the central segment or salt deposit diachronism. The positioning of the Brazilian salt boundary on Angolan-Namibian crust might indicate that the southeastern portion of the salt layer in Santos basin is underlain by volcanic crust, as proposed by Gladczenko et al., (1997), Mohriak, (2001) and Davison, (2005). Ponte et Asmus, 1976; Kumar et al., 1977; Cande \& Rabinowitz (1978b); Kumar et Gamboa, 1979, Sibuet et al., 1984, Gladczenko et al., (1998) suggested a ridge crest jump from an extincted spreading center in the eastern part of the Santos basin by Late Aptian. At this time, occurred simultaneously the opening of the Equatorial Atlantic Ocean occurred, allowing a possible connection between the North and South Atlantic Ocean waters (Eagles, 2006). As a matter of fact paleontological analysis of early post-salt sediments in the South Atlantic indicate an intriguing connection with North Atlantic Tethys fauna (Dias-Brito, 1982; Azevedo, 2004).

After this period, the northern part and the southern part of South America are not deformed. A small deformation still remains between these two parts, in the Paraná area. This deformation will last until chron C34, as already noticed by Gibert et al., (1989) and Campan (1995). 


\subsection{Intra-Albian (106 Ma)}

During Albian time, the opening of the Equatorial Atlantic and the South Atlantic Ocean continues.

Eagles (2006) presents a reconstruction for an intermediate stage at 102-96 Ma in order to take into account the "subtle change in FZ curvature about halfway" between the normalpolarity anomaly C34 and chron M0 (between 84 and 125 Ma after Gradstein et al., 2004). This change was already noticed by Rabinowitz \& LaBrecque (1979) and is similar to that one described by Marks \& Tikku (2001) one at 96Ma (Eagles, 2006). Nevertheles, this additional reconstruction implies an unreasonable intraplate deformation (90 to $130 \mathrm{~km}$ extension) in the Paraná area for this period.

On Figure 24, in the Austral Segment, the position Argentina - Salado - Rio de la Plata blocks is adjusted using one single intermediate C34-M0 pole. The small circles described by this Eulerian pole present small misfits $(<20 \mathrm{~km})$ with the FZs, but avoid irrational deformation in the Paraná area. These misfits may result from a deformation of the oceanic crust related to the volcanic activity of Walvis-Rio Grande Ridge. A small deformation still remains in the Paraná block. Gibert et al., (1989) and Campan (1995) already noticed this problem. Campan (1995) showed that it is impossible to correctly adjust both magnetic anomalies and fracture zones on the whole of the South Atlantic Ocean at Chron 34.

\section{Discussions}

\subsection{Age of the first oceanic crust}

The age of the first oceanic crust varies progressively from South to North as indicated by magnetic anomalies and flow lines.

South of the Austral segment, the age of the first accretion is linked to the age of the anomaly $G$ and depends on its determination, which fluctuates between anomaly M13 ( $139.5 \mathrm{Ma})$ (Rabinowitz \& LaBrecque, 1979) and anomaly M22 ( $150.5 \mathrm{Ma}$ according to Gradstein et al., 2004) (Du Plessis, 1977).

On the another hand, Courtillot et al. (1999) proposed a causal link between flood basalts and continental break-up. Thus, in the Central Atlantic Ocean, Sahabi et al. (2004) showed that the beginning of the seafloor spreading at Late Sinemurian (195Ma) coincides with the main tectonic and volcanic phase (Central Atlantic Magmatic Province: CAMP: 200Ma after Marzoli et al., 1999b). We therefore compiled published geochemical data and radiometric dates for the dikes and the lava flows (Figure 18). This compilation shows a peak of volcanic activity in the Late Hauterivian-Early Barremian (134-130 Ma after Gradstein et al., 2004). As our model presents an age for the tightest fit, which precedes the Chron M7 (132 Ma), we infer that the first oceanic crust in this southern area occurred between M9 and M7 (between 134 and $132 \mathrm{Ma}$ ), in the Hauterivian time. In the rest of the Austral segment, the first accretion occurred between chron M7 and M4 (132 and 130 Ma after Gradstein et al., 2004), in the Late Hauterivian. These results confirm the age proposed by Austin \& Uchupi (1982) for the first seafloor spreading in the Austral segment.

The Santos basin is an area of particular interest. Some authors noticed linear magnetic anomalies but their determination are not clear and their age varies from M3 to M0 (Cande \& Rabinowitz, 1978a, b). Taking into account the deformation in the Paraná area, our reconstructions propose that the Santos block started to move slowly between chrons M4 and M2. The presence of an intrabasinal ridge jump was first proposed by Pontes \& Asmus (1976) and Kumar \& Gamboa (1979). This ridge jump occurred after the deposition of the salt layer otherwise salt would be found in the Namibe basin (conjugate of the Santos basin), where the break-up occurred. We infer that this jump occurred at the same time as the rest of the central segment, where the first seafloor spreading is dated by the last salt deposition, 
which corresponds to the break-up, at the Aptian-Albian boundary around $112 \mathrm{Ma}$ (Moulin et al., 2005). Mohriak (2001) suggests that the oceanic propagator (Abimael Ridge) advanced from the Pelotas Basin, south of the Florianópolis Fracture Zone (São Paulo Ridge) towards the Santos Basin, but was aborted during the penetration in the Late Aptian salt layer, and was deflected in an en-echelon pattern towards the eastern margin of the salt basin, as the breakup progressed from Santos to Campos basins (Mohriak et al., 2008).

In the Equatorial Atlantic Ocean, Pontes \& Asmus, (1976), Szatmari et al. (1987), Matos (2000) on the basis of intensive onshore and offshore exploration, and then Mohriak (2003) and Zalan (2004) on the basis of compilation and analysis of new available data, dated the main phase of rifting at the Alagoas stage (Late Aptian). Pontes \& Asmus (1976) dated also the first marine sequence of the equatorial basins in the Early Albian. In agreement with these studies, our model shows that the opening of the Equatorial Atlantic Ocean occurred during the Aptian-Albian boundary, contemporenaous to the onset of seafloor spreading in the Central Segment. Moreover, the paleontological evidence of Tethyan influence in the Early Albian suggest that the opening of the Central Atlantic Seaway connecting the Aptian salt basin to the North Atlantic waters might have occurred by Late Aptian, either through the transform margin between the Amazon Cone and the Potiguar Basin (Ivory Coast to Nigeria in Africa), or through the Benue Trough.

\subsection{Kinematic evolution and intraplate deformation}

Our new model of kinematic evolution, based on FZs, new magnetic anomaly identification, other isochrons, flow lines, onshore and offshore geological and geophysical data and their full and simultaneous fitting made by a numerical trial-error method using PLACA software, is summarized on Figure 25.

We can summarize four stages:

Stage 1 - The Austral Segment: Between LMA and M4 the opening of this segment started following the massive outpouring of basalt lavas in the Paraná-Etendeka province. Major crustal discontinuities such as the NW lineaments in the Paraná Basin are associated with dike swarms in the Ponta Grossa Arch. Before M7 in the Orange and Argentine Basins, with deformation between Salado and Argentine blocks; this deformation stops at M7. After M7, the opening occurred between Walvis and Pelotas Basins, with the start of the movement of the Rio de la Plata block. North of the Paraná area and for the Austral African block, movements are very small during this period.

Stage 2 - The Santos "Buffer » block: Between M4 and until Aptian, the Santos block started to follow the general westward movement of the southern part of South America, whilst the Rio de la Plata bock and the Argentine-Salado block are connected between M4 and M2. The Santos block plays the role of a kinematic buffer between the movements that created the northern Aptian basins with rich source rock lacustrine sediment and salt deposition and the southern volcanic basins with narrow lacustrine rifts and no salt deposition of the South Atlantic Ocean. In the same period and until Late Aptian, the Austral African block moved slightly north-eastwards, allowing some extensional movement in the Central Segment. North of Santos basin, there were block movements affecting the salt basin. There is still some deformation in the Paraná area.

Stage 3 - The central segment: The Late Aptian/Early Albian limit marked the end of salt deposition and the opening of the central segment and coincided with the second stage of Guiraud \& Maurin (1992). The Santos Block is now connected to the northern part of the South Atlantic plate, and the opening of the central segment implies an eastward ridge jump, very close to the African coast, in the South Kwanza Basin, allowing a first "continuous" oceanic ridge from the Ascencion FZ in the north to the main limit of Walvis and Rio Grande FZ to the South. The Santos Basin system is therefore left on the Brazilian side. Between M0 and Late Aptian/Early Albian, the different blocks of the northern part of South America moved slightly to reach their presentday position in regard to the Guyana block. After the Late Aptian/Early Albian time no major intraplate deformation occurred both in the Africa and South America plates (except in the Paranà area). 
Stage 4 - The Equatorial Segment: In Albian time, the Equatorial Atlantic Ocean opened, allowing the definitive water connection between the Central Atlantic and the South Atlantic oceans.

As already noticed by Eagles (2006), the opening of the South Atlantic Ocean is mainly linked to the South American plate deformation. This deformation propagates northwards along six main basins already described by Eagles (2006), but with much older active periods. Our detailed model highlights the buffer role of the Santos block, between two very different segments, and gives precise reconstruction (especially for the initial fit) in coherence with geophysical and geological data. Contrary to Eagles (2006) reconstruction, but following Gibert et al., (1989) and Campan, (1995), we also highlighted an intraplate deformation in the Paraná area that exists until C34. Geochemical studies (Deckart et al., 1998; Hackspacher et al., 2004; Guedes et al., 2005) showed an alkaline volcanic episode at 82-83 Ma in the coast-parallel dike swarm near Rio de Janeiro. This event is currently explained by the arrival of the "Tristan da Cunha" plume. The constant misfits between fracture zones and magnetic anomalies are arguments for the existence of a link between the last stage of this old persistent intraplate deformation in the Paraná area and those post-breakup volcanic events. Another important tectono-magmatic event is registered in the Late Cretaceous - Early Tertiary, with manifestations of igneous activity around 60-50 Ma in the Cabo Frio region (Mizusaki et al., 2002). Reactivation of the large deformation zone in the northern part of the Paraná area might also be associated with this episode, which has often been interpreted as a hot-spot manifestation (Thomaz-Filho et al., 2005).

This new, precise model of evolution confirms the main hypothesis of Eagles (2006), but details and modifies the timing and the pre-break-up reconstructions on the South and Equatorial Atlantic Oceans. It minimizes the intraplate deformation as much as possible when no published works were found; the limits must be therefore regarded like symbolic lines where is compiled the amount of deformation diluted on larger areas; they indicate where the deformation related to each rifting/drifting event should be found. Following Eagles (2006), we also point out the importance of onshore studies, which will improve our knowledge of the timing and amount of deformation and offer opportunities to refine our model. This mainly applies for the area westwards of the Paraná Basin, which according to our model, should have experienced $125 \mathrm{~km}$ of compression towards the Andean bend.

The consequences induced by a pre-break-up kinematic reconstruction are tremendous for the genesis of continental passive margin that marked the break-up area (age, timing, constraints on movements) and on the timing of the first evolution of the oceanic crust (see, for example, Sahabi et al., 2004, Labails, 2007, Labails et al., 2007). The new initial fit presented in this study, based on satellite altimetry, oceanic and continental geological constraints and new interpretation of magnetic data, represents the tightest reconstruction that could be obtained and represent the base canvas on which the problem of the continental margin genesis should be addressed (Moulin, 2003; Aslanian et al., 2009). For instance, the presence of the significant depths of the Late Jurassic to Early Cretaceous petroleum-producing rifts of Reconcavo, Tucano, Jatobá, Sergipe-Alagoas, Gabon and Equatorial Guinea in the Central Segment of South America and Africa while the Africa plate has only started to move at M4 with very small horizontal movements, addresses the question of the relation between thinning and large horizontal movement in such areas. Like Aslanian et al., (2009) already have shown it in the Central segment, it seems most improbable that the continental crust maintains its integrity throughout this thinning process, which seems to mainly concern the lower/middle continental crust.

\section{Acknowledgement}

This research is mainly funded by the Ifremer and $M$. Moulin is also supported by LATTEX/IDL grant - ISLF-5-32 cofinanced by FEDER. We acknowledge L. Matias for fruitful 
discussions and his long-term assistance with the PLACA software. We also thank L. Gahagan for sending the poles of the program PLATES. The GMT software (Wessel \& Smith, 1995) package and the PLACA software (Matias et al., 2005, http://www.ifremer.fr/drogm/telechargement/placa_version_0_1) were used for the preparation of this paper. We also thank Marina Rabineau and Alison Chalm for their final language corrections. We acknowledge the two reviewers Pedro Zalán and Webster Mohriak for their useful comments and corrections and their invaluable help in research of the Brazilian bibliography.

\section{References}

Almeida, F.F.M. \& Black, R., 1967. Comparaison structurale entre le NE du Brésil et l'Ouest Africain. Symp. On Cont. Drift, Montevideo.

Almeida, F. F.M., Susczczynski, E. F. \& Derze, G. R., 1970. Mapa tectônico do Brasil, Ministério das Minas e Energia.

Araújo, L.M., Triguis, J.A. Cerqueira, J.R. \& da S. Freitas, L.C., 2000. The atypical Permian petroleum system of the Paraná Basin, Brazil. In: Mello M.R. and B.J. Katz, (Editors), Petroleum systems of South Atlantic margins, AAPG Memoir 73: pp. 377-402.

Aslanian, D., Moulin, M. Olivet, J.-L, Unternehr, P., Matias, L., Bache, F., Rabineau, M., Nouzé, H., Klingelhoefer, F., Contrucci, I. \& Labails, C., 2009. Brazilian and African passive margins of the Central Segment of the South Atlantic Ocean: kinematic constraints, Tectonophysics (Special Issue: role of magmatism), 468: 98-112.

Aslanian, D. \& Moulin, M., Comment on 'A new scheme for the opening of the South Atlantic Ocean and the dissection of an Aptian salt basin' by Torsvik, Rousse, Labails \& Smethurst, submitted to Geophysical Journal International.

Asmus, H. E. \& Ponte, F.C., 1973. The Brazilian marginal basins. In: E. A. M. Nairn \& F. G. Stelhi (Editors), The Oceans basins and margins. Vol.1: The South Atlantic, Plenum Press, New-York, pp. 87-133.

Asmus, H.E., 1984. Geologia da margem continental brasileira. In: C. Schobbenhaus, D. A. Campos, G. R. Derze, and H. E. Asmus (eds.), Geologia do MME/DPNPM, Brasília, Brasil, p. 443-472.

Austin, J. A. \& Uchupi, E., 1982. Continental-oceanic crustal transition off Southwest Africa. American Association of Petroleum Geologists Bulletin 66: 1328-1347.

Austin, G.H. \& Howie, R.D. 1973. Regional geology of offshore Eastern Canada. In: Hood, P.S, McMillan \& Pelletier B.R. (Editors), Earth Sci. symp. On offshore Eastern Canada. Pap. Geol. Surv. Canada 71-13, pp. 73-107.

Azevedo, R. L. M., 2004. Paleoceanografia e a evolução do Atlântico Sul no Albiano. Boletim de Geociências da Petrobras, Rio de Janeiro, v. 12, n. 2, p. 231-249.

Bauer, K., Neben, S., Schreckenberger, B., Emmermann, R., Hinz, K., Fechner, N., Gohl, K., Schulze, A., Trumbull, R.B. \& Weber, K. 2000. Deep structure of the Namibia continental margin as derived from integrated geophysical studies. Journal of Geophysical Research 105: 25829-25853.

Benkhelii, J., 1988. Structure et Evolution du bassin de la Bénoué. Bulletin des Centres de Recherches Exploration-Production, Elf Aquitaine 12: 29-128.

Bertrand H. \& Westphal, M., 1977 Comparaisons géologiques et paléomagnétiques des tholeïtes du Maroc et de la côte orientale de l'Amérique du Nord: implications pour l'ouverture de l'Atlantique, Bull. Soc. Géol. France, 7 XIX 3, $513-520$.

Black, R. \& Girod, M., 1970. Late Paleozoic to Recent igneous activity in West Africa and its relationship to basement structure. Afr. Magm. and Tect., a vol. in honour of W. Q. Kennedy, Clifford, Ed., 185-210.

Blarez, E. 1986. Structure et évolution d'une marge continentale transformante. Paris, Univ. Pierre et Marie Curie, Paris VI: 188 pp.

Bonnin, J. 1978. Evolution géodynamique de la ligne Açores-Gibraltar. Paris, Univ. Paris VII: $144 \mathrm{pp}$. 
Bosworth, W. \& Morley, C.K., 1994. Structural and stratigraphic evolution of the Anza rift, Kenya. Tectonophysics 236: 93-115.

Boudjema, A., 1987. Evolution structurale du bassin petrolier «triasique » du Sahara Nord oriental Algérie. Thèse, Univ. Paris Sud, Paris, 290 pp.

Brognon, G. P. \& Verrier, G. V., 1966. Oil and geology in Cuanza basin of Angola. American Association of Petroleum Geologists Bulletin, $50: 108-158$.

Bueno, G.V., 2004. Diacronismo de eventos no rifte Sul-Atlântico. Boletim de Geociências da Petrobras, Rio de Janeiro, v. 12, n. 2, p. 203-229.

Bullard, E. C., Everett, J.E. \& Smith, A.G. 1965. The fit of the continents around the Atlantic. In: Symposium on Continental Drift. Philos. Trans. R. Soc. London 258Ser. A: 41-51.

Burke, K. \& Dewey, J.F. 1974. Two plates in Africa during the Cretaceous? Nature, 249: 313316.

Butler, L.W., 1970. Shallow structure of the continental margin, Southern Brazil and Uruguay. Geological Society of America Bulletin, 18: 1079-1096.

Caby, R., 1989. Precambrian terranes of Benin-Nigeria and northeast Brazil and the Late Proterozoic south Atlantic fit. Geological Society of American Special Paper 230: 145-158.

Cainelli, C. \& Mohriak, W.U., 1998. Geology of Atlantic Eastern Brazilian basins. 1998 AAPG International Conference \& Exhibition Short Course - Brazilian Geology Part II, November 8 - 11, 1998, Rio de Janeiro, Brazil, 67 p. + figures.

Campan, A., 1995. Analyse cinématique de l'Atlantique Equatorial, implications sur l'évolution de l'Atlantique Sud et sur la frontière de plaque Amérique du Nord / Amérique du Sud. Paris, Univ. Pierre et Marie Curie, Paris VI: 352 pp.

Cande, S. C., LaBrecque, J. L. \& Haxby, W. F. 1988. Plate kinematics of the South Atlantic: Chron C34 to Present. Journal of Geophysical Research 93B11: 13479-13492.

Cande, S. C. \& Rabinowitz, P. D. 1978. Magnetic Anomalies on the Continental Margin of Brazil, Lamont-Doherty Geological Observatory: 1 map.

Cande, S.C. \& Rabinowitz, P.D., 1978b. Mesozoic seafloor spreading bordering conjugate continental margins of Angola and Brazil. $10^{\text {th }}$ Annual Offshore Techonology Conference, Houston, Tex. May 8-11, OTC 3268, p.1869-1876.

Carey, S. W. 1955. Wegener,'s South America-Africa Assembly, Fit or Misfit ? Geological Magazine 92: 196-200.

Choubert, G., Faure-Muret, A. \& Sougy, J., 1968. Carte Tectonique Internationale de l'Afrique, UNESCO, 9 cartes.

Cochran, J.R., 1982. The magnetic quiet zone in the eastern gulf of Aden: implications for the early development of the continental margin. Geophys. J. R. Astr. Soc., 68: 171-201.

Conceição, J. C. de J., Zalán, P. V. \& Wolff, S., 1988. Mecanismo, Evolução e cronologia do rift sul-atlântico (Mechanism, evolution and chronology of South Atlantic Rifting). Bol. Geoci. Petrobras, Rio de Janeiro, 2 (2/4): 255-265.

Contrucci, I., Matias, L, Moulin, M., Géli, L., Klingelhoeffer, F., Nouzé, H., Aslanian, D., Olivet, J.-L., Sibuet, J.-C. \& Réhault, J.-P., 2004. Deep structure of the West African continental margin, between $5^{\circ} \mathrm{S}$ and $8^{\circ} \mathrm{S}$, from reflection / refraction seismics and gravity data. Geophysical Journal International $158: 529-553$.

Corner, B., Cartwright, J. \& Swart, R., 2002. Volcanic passive margin of Namibia: A potential fields perspective. Volcanic Rifted Margins. In: M. A. K. Menzies, S.L.; Ebinger, C.J. \& Baker, J. Boulder (Editors), Colorado, Geological Society of America, Special Paper. 362: 203-220.

Cornacchia, M., 1986. Carte géologique du NE de la République Centrafricaine. 51 pages, 12 fig. 2 tab., 2 c. Musée Royal de l'Afrique Centrale, Distributed by NHBS.

Cornacchia, M. \& Dars, R., 1983. Un trait structural majeur du continent africain. Les linéaments centrafricains du Cameroun au Golfe d'Aden. Bulletin de la Société Géologique de France 1: 101-109.

Courtillot, V., 1982. Propagating rifts and continental breakup. Tectonics 13: 239-250.

Courtillot, V., Jaupart, C., Manighetti, I., Tapponnier, P. \& Besse, J., 1999. On causal links between flood basalts and continental breakup. Earth and Planetary Science Letters 166: 177-195. 
Curie, D., 1984. Ouverture de l'Atlantique sud et discontinuités intra-plaque: une nouvelle analyse. Brest, Univ. de Bretagne Occidentale: 192 pp.

Davison, I., 2005. Tectonics of the South Atlantic Brazilian Salt Basin. In: GCSSEPM 25th Annual Bob F. Perkins Research Conference: Petroleum Systems of Divergent Continental Margin Basins, Abstracts CD, p. 468-480.

Deckart, K., Féraud, G., Marques, L. S. \& Bertrand H. 1998. New time constraints on dyke swarms related to the Paranà-Etendeka magmatic province, and subsequent South Atlantic Opening, southeastern Brazil. Journal of Volcanology and Geothermal Research 80: 67-83.

Dias-Brito, D., 1982. Evolução paleoecológica da Bacia de Campos durante a deposição dos calcilutitos, marga e folhelhos da Formação Macaé (Albiano e Cenomaniano?). Boletim Técnico da PETROBRAS, Rio de Janeiro, v. 25, n. 2, p. 84-97.

Dickson, W. G., Fryklund, R. E., Odegard, M. E. \& Green, C. M. 2003. Constraints for plate reconstruction using gravity data-implications for source and reservoir distribution in Brazilian and West African margin basins. Marine and Petroleum Geology 20: 309-322.

Dietz, R. S. 1973. Morphologic fits of North America/Africa and Gondwana: a review. Implications of Continental Drift. D. M. T. a. S. K. R. Editors. London, Academic Press. 2: 865-872.

Dumont, J.-F. 1986. Identification par télédétection de l'accident de la Sanaga Cameroun Sa position dans le contexte des grands accidents d'Afrique Centrale et de la limite nord du craton congolais. Géodynamique 1: 13-19.

Dumont, J.-F. 1987. Etude structurale des bordures nord et sud du plateau de l'Adamaoua: influence du contexte atlantique. Géodynamique 2: 55-68.

Du Plessis, A., 1977. Seafloor spreading south of the Agulhas Fracture Zone. Nature 270: 719-721.

Eagles, G., 2006. New angles on South Atlantic Opening. Geophysical Journal Interntional 7:28: doi: 10.1111/j.1365-246X.2006.03206.x.

Eagles, G. \& Konig, M., 2008. A model of plate kinematics in Gondwana breakup. Geophysical Journal International, v. 173, p. 703-717.

Emery, K.O., Uchupi, E., Phillips, J., Bowin, C. \& Mascle, J., 1975. Continental Margin off Western Africa: Angola to Sierra Leona. American Association of Petroleum Geologists Bulletin 59: 2209-2265.

Ewart, A.J., Marsh, J.S., Duncan, A.R., Miller, R.M, Hawkesworth, C.J., Betton, P.J. \& Rex, D.C., 1894. Geochemistry and petrogenesis of the Etendeka volcanic rocks from SWA/ Namibia. In: Erlank, A.J. (Ed.), Petrogenesis of Volcanic Rocks of the Karoo Province, Geological Society of South Africa Special Publication, Johannesburg, 13: 195-245.

Ewart, A.J. Milner, C.S., Duncan, A.R. \& Bailey, R., 2002. The Cretaceous Messum igneous complex, S.W. Etendeka, Namibia: reinterpretation in terms of a downsag-cauldron subsidence model. Journal of Volcanology and Geothermal Research 114: 251-273.

Eyles, N. \& Eyles C. H. 1993. Glacial geologic confirmation of an intraplate boundary in the Paraná basin of Brazil. Geology 21: 459-462.

Fainstein, R. \& Milliman, R., 1979. Structure and origin of three continental-margin plateaus, northeastern Brazil. American Association of Petroleum Geologists Bulletin, v. 63, n. 2, p. 218-238.

Fairhead, J. D. 1988. Mesozoic plate tectonic reconstructions of the central South Atlantic Ocean: The role of the West and Central African rift system. Tectonophysics 155: 181-191.

Fairhead, J. \& Maus, S., 2003. CHAMP satellite and terrestrial magnetic data help define the tectonic model for South America and resolve the lingering problem of the pre-break-up of the South Atlantic Ocean. The Leading Edge 779-783.

Fidalgo Gonzáles, L. 2001. La cinématique de l'Atlantique Nord: la question de la déformation intraplaque. Brest, Univ. de Bretagne Occidentale: $260 \mathrm{pp}$.

Fontana, R.L., 1996. SDR (Seaward-dipping reflectors) e a transição crustal na Bacia de Pelotas. Anais do $39^{\circ}$ Congresso Brasileiro de Geologia, SBG, Salvador - Bahia, v. 5, p. $425-430$. 
Franke, D., Neben, S., Schreckenberger, B., Schulze, A., Stiller, M. \& Krawczyk, C.M. 2006. Crustal structure across the Colorado Basin, offshore Argentina. Geophysical Journal Interntional doi: 10.1111/j.1365-246X.2006.02907.x: 1-15.

Franke, D., Neben, S., Ladage, S., Schreckenberger, B. \& Hinz, K. 2007. Margin segmentation and volcano-tectonic architecture along the volcanic margin off Argentina/Uruguay, South Atlantic. Marine Geology 244: 46-67, doi:10.1016/j.margeo.2007.06.009.

Franks S. \& Nairn, A.E.M. 1973. The equatorial marginal basins of West Africa. In: E. A. M. Nairn \& F. G. Stelhi (Editors), The Oceans basins and margins. The South Atlantic, Plenum Press, New-York, pp. 301-350.

Frindt, S., Trumbull, R.B. \& Romer, R.L., 2004. Petrogenesis of the Gross Spitzkoppe topaz granite, central western Namibia: a geochemical and $\mathrm{Nd}-\mathrm{Sr}-\mathrm{Pb}$ isotope study. Chem. Geol. 206: 43-71.

Genik, G. J., 1992. Regional Framework and structural aspects of rift basins in Niger, Chad and the Central African Republic. In: P.A. Ziegler (Editor), Geodynamics of Rifting, Volume II. Case History Studies on Rifts: North and South America. Tectonophysics, 213: 169-185.

Gerrard, I. \& Smith, G. C., 1982. Post-Paleozoïc succession and structure of the southwestern African continental margin. American Association of Petroleum Geologists Memoir, 34 : 49-74.

Gibert, D., Courtillot, V. \& Olivet, J.-L., 1989. Seasat Altimetry and the South Atlantic Geoid 2. Short-Wavelength Undulations. Journal of Geophysical Research 94: 5545-5559.

Girdler, R.W. \& Styles, P., 1978. Seafloor spreading in the western Gulf of Aden. Nature, 271: 615-617.

Gladczenko, T. P., Hinz, K., Eldholm, O., Meyer, H., Neben, S. \& Skogseid, J., 1997. South Atlantic volcanic margins. Journal of the Geological Society, London, 154: 465-470.

Gladczenko, T. P., Skogseid, J. \& Eldhom, O., 1998. Namibia volcanic margin. Marine Geophysical Research, 20: 313-341.

Gradstein, F. M., Ogg, J. G. \& Smith, A. G., 2004. A Geologic Time Scale. Cambridge.

Gondcalves de Souza, K., 1991. La marge continentale brésilienne sud-orientale et les domaines océaniques adjacents: structure et evolution. Ph. D Thesis, Univ Pierre et Marie Curie, Villefranche sur Mer, 230 pp.

Goodlad, S.W., Martin, A.K. \& Hartnady, C.J.H., 1982. Mesozoic magnetic anomalies in the Southern Natal Valley. Nature 295: 686-688.

Gouyet, S., 1988. Evolution tectono-sédimentaire des marges guyanaises et nord-brésilienne au cours de l'ouverture de l'Atlantique Sud. Thèse de doctorat, Univ. de Pau et des pays de l'Adour, Pau, 374 pp.

Guedes, E., Heilbron, M., Vasconcelos P.M., de Morisson Valeriano C., Horta de Almedia, J. C., Teixeira, W. \& Filho A. T. 2005. K-Ar and ${ }^{40} \mathrm{AR} /{ }^{39} \mathrm{Ar}$ ages of dikes emplaced in the onshore basement of the Santos Basin, Resende area, SE Brazil: implications for the south Atlantic opening and Tertiary reactivation. Journal of South American Earth Sciences 18: 371-382.

Gueguen, E., 1995. Le bassin Liguro-Provencal, un véritable océan. Exemple de segmentation des marges et de hiatus cinématiques. Implications sur les processus d'amincissement crustal. Brest, Univ. de Bretagne Occidentale: 309 pp.

Guiraud, R. \& Alidou., S. 1981. La faille de Kandi Bénin, témoin du rejeu fini-crétacé d'un accident majeur à l'échelle de la plaque africaine. Compte Rendus Geosciences 293: 779782.

Guiraud, R. \& Maurin, J.C., 1992. Early Cretaceous rifts of Western and Central Africa: an overview. Tectonophysics 213: 153-168.

Guiraud, R., Doumnang, J.-C., Mbaigane, Carretier, S. \& Dominguez, S., 2000. Evidence for a $6000 \mathrm{~km}$ length NW-SE-striking lineament in northern Africa: the Tibesti Lineament. Journal of the Geological Society of London, 157: 897-900.

Hackspacher, P.C., Ribeiro, L.F.B., Ribeiro, M.C.S., Fetter, A.H., Hadler Neto, J.C., Tello, C.E.S. \& Dantas, E.L., 2004. Consolidation and Break-up of the South American Platform in 
Southeastern Brazil: Tectonothermal and Denudation Histories. Gondwana Research 7,1: 91-101

Hawkesworth, C.J., Gallagher, K., Kelley, S., Mantovani, M., Peate, D.W., Regelous, M., Rogers, N.W., 1992. Paraná magmatism and the opening of the South Atlantic, In: Storey, B.C., Alabaster, T., Pankhurst, R.J. (Editors), Magmatism and the Causes of Continental Break-Up. Special Publication of the Geological Society of London 68: pp. 221-240.

Hayes, D.E. \& Ewing, M., 1970. North Brazilian Ridge and adjacent continental margin. The Am. Ass. Petrol. Geol. Bull. 54: 2120-2150.

Heilbron, M., Mohriak, W. U., Valeriano, C. M., Milani, E. J., Almeida, J. \& Tupinambá, 2000. From collision to Extension: The roots of Southeastern Continental Margin of Brazil. In : W. Mohriak \& M. Talwani (Editors), Atlantic Rifts and Continental Margins, AGU 115 : pp. 1-32.

Hinz, K., 1981. A hypothesis on terrestrial catastrophes: wedges of very thick oceanward dipping layers beneath passive continental margins. Geol. J. E22: 3-28.

Hinz, K., Neben, S., Schreckenberger, B., Roeser, H. A., Block, M., Goncalves de Souza, K. \& Meyer, H., 1999. The Argentine continental margin north of 48 degrees S; sedimentary successions, volcanic activity during breakup. Marine and Petroleum Geology 161: 1-25.

Jacques, J. M., 2003a. A tectonostratigraphic synthesis of the Sub-Andean basins: implications for the geotectonic segmentation of the Andean Belt. Journal of the Geological Society, London 160: 687-701.

Jacques, J. M., 2003b. A tectonostratigraphic synthesis of the Sud-Andean basins: inferences on the position of the South American intraplate accommodation zones and their control on South Atlantic opening. Journal of the Geological Society, London 160: 703-717.

Jorgensen, G.J. \& Bosworth, W., 1988. Gravity modelling in the Central African Rift System, Sudan: Rift geometries and tectonic significance. In: B. Rosendahl (Editor), Journal of African Earth Sciences Special Publication 8, 2-4: pp. 283-306.

Karner, G. D. \& Driscoll, N. W., 1999. Tectonic and stratigraphic development of the West African and eastern Brazilian Margins: insights from quantitative basin modelling. In: Cameron, N. R., Bate R. H. \& Clure, V. S., (Editors), The oil and gas habitats of the South Atlantic, Geol. Soc. London, Spec. Publ, 153: pp. 11-40.

Klitgord, K. \& Schouten, H., 1986. Plate kinematics of the Central Atlantic. The Geology of North America. In: Vogt, P. R. \& Tucholke, B. E. (Editors). vol. M: The Western North Atlantic Region, Boulder, CO, Geological Society of America: pp. 351-378.

König, M. \& Jokat, W., 2006. The Mesozoic breakup of the Weddell Sea. Journal of Geophysical Research 111B12102, doi:10.1029/2005JB004035: 1-28.

Kristoffersen, Y., 1978. Sea floor spreading and the early opening of the North Atlantic. Earth and Planetary Science Letters 38: 273-290.

Kumar N., Gamboa L. A. P., Mascle J., \& Schreiber B.C., 1977. Geologic history and origin of Sao Paulo Plateau (southeastern Brazilian margin), comparison with the Angolan margin and the early evolution of northern South Atlantic. Init. Repts of the D.S.D.P., Washington, U.S. Gvt Printing Office, 39, 927-945.

Kumar, N. \& Gambôa, L.A.P., 1979. Evolution of the São Paulo Plateau southeastern Brazilian Margin and implications for the early history of the South Atlantic. Geological Society of American Bulletin 90: 281-293.

Labails., C. 2007. La marge sud-marocaine et les premières phases d'ouverture de l'océan Atlantique Central. Ph. D Thesis, Univ de Bretagne Occidentale, Brest, 2 vol., 276 pp, http://tel.archives-ouvertes.fr/tel-00266944/fr.

Labails, C., Olivet, J.-L., Aslanian, D., Sichler, B., Roest, W. \& Evain, M., 2007. Mesozoic Kinematic Evolution of the Central Atlantic Inferred From Regional Magnetic Anomalies. AGU Fall Meeting, San Francisco, pp. GP33D-1598.

Larson, R.L \& Hilde, .W.C., 1975. A revised time scale of magnetic reversals for the Early Cretaceous, Late Jurassic. Journal of Geophysical Research 80: 2586-2594.

Laugthon, A. S., Whitmarsh, R., B. \& Jones M., T., 1970. The evolution of the Gulf of Aden. Phil. Trans. Roy. Soc. Lon., A 267: 227-266.

Lawver, L.A., Gahagan, L. \& Dalziel, I.W.D., 1999. A Tight fit-early Mesozoic Gondwana, a plate reconstruction perspertive. In: Motoyoshi, Y. and Shiraishi, K. (Editors), Origin and 
Evolution of Continents: Proceedings of the International Symposium Origin and Evolution of Continents, 13-14 October, 1997, Tokyo, Memoirs of National Institute of Polar Research, Special Issue 53: 214-229.

Lehner, P. \& De Ruiter, P. A. C., 1977. Structural history of Atlantic margin of Africa. American Association of Petroleum Geologists Bulletin, 61: 961-981.

Le Pichon, X. \& Hayes, D. E. 1971. Marginal Offsets, Fracture Zones and the Early Opening of the South Atlantic. Journal of Geophysical Research 7626: 6283-6293.

Leyden, R., Bryan, G. \& Ewing, M. 1972. Geophysical Reconnaissance on African Shelf: 2. Margin Sediments from Gulf of Guinea to Walvis Ridge. Association of Petroleum Geologists Bulletin, 56: 682-693.

Leyden, R., Asmus, H., Zembruscki, S. \& Bryan, G., 1976. South Atlantic diapiric structures. American Association of Petroleum Geologist Bulletin 60: 196-212.

Lustrino, M., Melluso, L., Brotzu, P., Gomes, C. B., Morbidelli, L., Muzio, R., Ruberti, E. \& Tassinari, C. C.G. 2005. Petrogenesis of the Early Cretaceous Valle Chico igneous complex SE Uruguay: Relationships with Parana-Etendeka Province. Lithos 82: 407-434.

MacDonald, D., Gomez-Perez, I., Franzese, J., Spalleti, L., Lawver, L., Gahagan, L., Dalziel, I., Thomas, C., Trewin, N., Hole, M. \& Paton, D. 2003. Mesozoic break-up of SW Gondwana: implications for regional hydrocarbon potential of the southern South Atlantic. Marine and Petroleum Geology 20: 287-301.

Mantovani, M.S.M., Marques, L.S., DeSouza, M.A., Civetta, L., Atalla, L. \& Innocenti, F., 1985. Trace element and strontium isotope constraints on the origin and evolution of Paranà continental flood basalts of Santa Caterina State Southern Brazil. Journal of Petrology 26: 187-209.

Marks, K.M. \& Tikku, A.A., 2001. Cretaceous reconstructions of East Antarctica, Africa and Madagascar. Earth and Planetary Science Letters 186: 479-495.

Marton, G., L, Tari, G. C. \& Lehmann C. T., 2000. Evolution of the Angolan Passive Margin, West Africa, with Emphasis on Post-Salt Structural Styles. In: W. Mohriak \& M. Talwani (Editors), Atlantic Rifts and Continental Margins : American Geophysical Union, 115 : 129149.

Martin, A. K., Hartnady, C.J.H. \& Goodlad, S.W., 1981. A revised fit of South America and South Central Africa. Earth and Planetary Science Letters 54: 295-305.

Martin, A K, Goodlad, S W, Hartrnady, C J H \& Du Plessis, A., 1982. Cretaceous palaeopositions of the Falkland Plateau relative to southern Africa using Mesozoic seafloor spreading anomalies. Geophysical Journal of the Royal Astronomical Society 71: 567-79.

Martin, A. K., 1984. Propagating Rifts: Crustal extension during continental rifting. Tectonics 36: 611-617.

Marzoli, A., Melluso, L., Morra, V., Renne, P.R., Sgrosso, I., D'Antonio, M., Duarte Morais, L., Morais, E.A.A. \& Ricci., G. 1999a. Geochronology and petrology of Cretaceous basaltic magmatism in the Kwanza basin western Angola, and relationships with the ParanàEtendeka continental flood basalt province. Journal of Geodynamics 28:341-356.

Marzoli, A., Renne, P. R., Piccirillo, E. M., Ernesto, M., Bellieni, G. \& DeMin, A., 1999b. Extensive 200-Million-Year Old Continental Flood Basalts of the Central Atlantic Magmatic Province. Sciences, 284: 616-618.

Mascle, J. \& Sibuet, J.C., 1974. New pole of early opening of South Atlantic. Nature 252: 464-465.

Mascle, J.\& Renard, V., 1976. The marginal Sao Paulo Plateau, comparison with the southern Angolan margin. In: de-Almeida-F. F. M. (Editor), Simposio internacional sobre as margens continentais de tipo atlantico. Anais da Academia Brasileira de Ciencias. 48; Suplemento pp. 179-190.

Matias, L. M., Olivet, J.-L., Aslanian, D. \& Fidalgo González, L., 2005. PLACA: A White Box for Plate Reconstruction and Best-Fit Pole Determination. Computers and Geosciences 31: 437-452.

Matos, R. M. D., 2000. Tectonic Evolution of the Equatorial South Atlantic. In W. Mohriak \& M. Talwani (Editors), Atlantic Rifts ans Continental Margins: Geophysical Monograph, 115: 331-353. 
Maurin, J.-C. \& Guiraud, R., 1993. Basement control in the development of the Early Cretaceous West and Central African Rift System. Tectonophysics 228: 81-95.

Max, M. D., Ghidella, M., Kovacs, L., Paterlini, M. \& Valladares, J.A., 1999. Geology of the Argentine continental shelf and margin from aeromagnetic survey. Marine and Petroleum Geology 16: 41-64.

May, P.R., 1971. Pattern of Triassic-Jurassic diabase dikes around the North Atlantic in the context of the predrift configuration of the continents, Geol. Soc. Am. Bull. 82: 1285-1292.

Meyers, J. B., Rosendahl, B. R. \& Austin, J. A., 1996. Deep penetrating MCS images of the South Basin: implications for rift tectonics and post-breakup salt remobilisation. Basin Research 8: 65-84.

Milani, J.E. \& Davison, I., 1988. Basement control and transfer tectonics in the RecôncavoTucano-Jatobá rift, Northeast Brazil. Tectonophysics 154: 41-70.

Milner, S.C., le Roex, A.P. \& O'Connor, J.M., 1995. Age of Mesozoic igneous rocks in northwest Namibia, and the relationship to continental breakup. J. Geol. Soc. London 151: 97-104.

Mizusaki, A.M.P., Thomaz-Filho, A., Milani, E.J. \& Césero, P., 2002. Mesozoic and Cenozoic igneous activity and its tectonic control in northeastern Brazil. Journal of South American Earth Sciences, v. 15 (2) (2002) p. 183-198.

Mohriak, W.U., 2001. Salt tectonics, volcanic centers, fracture zones and their relationship with the origin and evolution of the South Atlantic Ocean: geophysical evidence in the Brazilian and West African margins. 7 th INTERNATIONAL CONGRESS OF THE BRAZILIAN GEOPHYSICAL SOCIETY, Salvador - Bahia - Brazil, October 28-31, 2001, Expanded Abstract, p. 1594.

Mohriak, W. U., 2003. Bacias Sedimentares da Margem Continental Brasileira. In: L. A. Bizzi, C. Schobbenhaus, R. M. Vidotti e J. H. Gonçalves (Editors), Geologia, Tectônica e Recursos Minerais do Brasil, Capítulo III, p. 87-165, CPRM, Brasília.

Mohriak, W.U. \& Rosendahl, B.R., 2003. Transform zones in the South Atlantic rifted continental margins. In: Storti, F., Holdsworth, R.E., and Salvini, F. (eds.), Intraplate strikeslip deformation belts. Geological Society, London, Special Publication, 210, p. 211-228.

Mohriak, W.U., 2004. Recursos energéticos associados à ativação tectônica mesozóicocenozóica da América do Sul. In: V. Mantesso - Neto, A. Bartorelli, C.D.R. Carneiro and B.B.Brito-Neves (eds.), Geologia do continente sul-americano: evolução da obra de Fernando Flávio Marques de Almeida, Beca Produções Culturais Ltda., São Paulo, cap. XVIII, p. $293-318$.

Mohriak, W.U., Nemcok, M. \& Enciso, G., 2008. South Atlantic divergent margin evolution: rift-border uplift and salt tectonics in the basins of SE Brazil. In: Pankhurst, R.J., Trouw, R.A.J., Brito Neves, B.B. \& de Wit, M.J. (eds.), West Gondwana pre-Cenozoic correlations across the South Atlantic region. Geological Society, London, Special Publications, v. 294, p. 365-398.

Moulin, M. 2003. Etude géologique et géophysique des marges continentales passives: exemple du Zaïre et de l'Angola. , Ph. D. Thesis Univ. de Bretagne Occidentale, Brest: 2 vol., 360 pp, http://www.ifremer.fr/docelec/doc/2003/these-82.pdf.

Moulin, M., Aslanian, D., Olivet, J-L., Contrucci, I., Matias, L., Géli, L., Klingelhoeffer, F., Nouzé, H. and. Réhault, J-P \& Unternehr, P., 2005. Geological constraints on the evolution of the angolan margin based on reflection and refraction seismic data ZaïAngo project . Geophys. J. Int. 162: 793-810.

Moulin, M., Aslanian, D., Olivet, J-L. \& P. Unternehr, Typologie des marges - 1ere Partie l'Atlantique Sud, Rapport confidentiel, TOTAL, mai. 2006.

Müller, D., Roest, W.D., Royer, J.Y., Gahagan, L.M. \& Sclater, J.G., 1997. Digital Isochrons of the world's ocean floor. Journal of Geophysical Research, 102: 3211-3214.

Müller, R.D., Royer, J-Y., Cande, S.C., Roest, W.R., and Maschenkov, S., 1999. New constraints on the Late Cretaceous/Tertiary plate tectonic evolution of the Caribbean, in Caribbean Basins. In : P. Mann (Editor), Sedimentary Basins of the World series, Elsevier Science B.V., Amsterdam, The Netherlands, 4: 33-59. 
Needham H.D., Carré Daniel, Sibuet, J.-C., 1986. Carte bathymétrique de la ride de Walvis et du Bassin du Cap, Océan Atlantique Sud, 1 :4382832. 4 maps, Ifremer.

Norton, I. O. \& Sclater, J.G. 1979. A model for the evolution of the Indian Ocean and the breakup of the Gondwanaland. Journal of Geophysical Research 84: 6803-6830.

Nürnberg, D. \& Müller, R. D. 1991. The tectonic evolution of the South Atlantic from Late Jurassic to present. Tectonophysics 191: 27-53.

Nunns, A. G., 1983. The structure and evolution of the Jan Mayen Ridge and surronding regions. In: Warkins J. S. \& Drake, C. L. (Editors). Continental Margin Geology. Memoirs of the American Association of Petroleum Geologists, 34: pp. 193-208.

Oliveira Marinho, M., 1985. Le plateau marginal de Guinée: Transition entre Atlantique Central et Atlantique Equatorial. Thèse de doctorat, Univ. Pierre et Marie Curie, Paris VI, 183 pp.

Olivet, J.-L. 1978. Un nouveau modèle d'évolution de l'Atlantique Nord Central. Thèse d'état, Univ. Paris VII.

Olivet, J. L., Bonnin, J., Beuzart, P. \& Auzende, J.M. 1984. Cinématique de l'Atlantique Nord et Central. Publ. Rapp. Sci. Tech. Brest, Cent. Natl. Explor. Oceans: 108 pp.

Olivet, J. L. 1996. La cinématique de la plaque ibérique. Bull. Centres Rech. Explor. Prod. Elf-Aquitaine 20: 131-195.

Patriat, P., Segoufin, J, Schlich, R., Goslin, J., Auzende, J.-M., Beuzart, P., Bonnin, J. \& Olivet, J.-L. 1982. Les mouvements relatifs de l'Inde, l'Afrique et de l'Eurasie. Bull. Soc. Geol. France 7, 24: 363-373.

Pautot, G., Renard, V., Daniel, J. \& Dupont, J., 1973. Morphology, limits, origin and age of salt layer along South Atlantic African margin. American Association of Petroleum Geologists Bulletin 57: 1658-1671.

Pindell, J. \& Dewey, J. F., 1982. Permo-triassic reconstruction of western pangea and the evolution of the Gulf of Mexico/Caribbean region. Tectonics 1, 2: 179-211.

Pitman, W. C., III \& Talwani, M., 1972. Sea-floor spreading in the North Atlantic. Geological Society of America Bulletin, 83: 619-646.

Pontes, F.C, and Asmus, H.E., 1976. The brazilian marginal basins: Current state of knowledge. In: Proc. Internat. symposium on continental margins of Atlantic type, Sao Paulo, Brazil, Oct 13-17, 1975: Anais da Academia Brasileira de Ciências, v. 48, Supplement, p. 215-329.

Popoff, M., 1988. Du Gondwana à l'Atlantique sud : les connections du fossé de la Bénoué avec les bassins du Nord-Est bresilien jusqu'à l'ouverture du golfe de Guinée au Crétacé inférieur. Journal of African Earth Sciences Special Publication 7, 2: 409-431.

Rabinowitz, P.D., 1976. A geophysical study of the continental margin of the Southern Africa. Geol. Soc. Amer. Bull. 87:1643-1653.

Rabinowitz, P. D., Cande, S. C., \& LaBrecque, J. L., 1976. The Falkland escarpment and Agulhas Fracture Zone: the boundary between oceanic and continental crust at conjugate continental margins. An. Acad. Bras. Cienc, 48: 241-251

Rabinowitz, P. D., \& LaBrecque, J. 1979. The Mesozoic South Atlantic Ocean and Evolution of Its Continental Margins. Journal of Geophysical Research 84: 5973-6002.

Rapela, C.W.; Días, G.F.; Franzese, J.R.; Alonso, G.; Benvenuto, A.R. 1991. El Batolito de la Patagonia Central: evidencias de un magmatismo triásico- jurásico asociado a fallas transcurrentes. RevistaGeológica de Chile 18, 2: 121-138.

Rapela, C. W. \& Pankhurst, R. J., 1992. The granites of northern Patagonia and the Gastre Faut System in relation with the break-up of Gondwana. In: Storey, B C, Alabaster, T and Pankhurst, R J (Editors). Magmatism and the causes of continental break-up. Geological Society Special Publication 68: pp. 209-220.

Reeves, C. 2000. The geophysical mapping of Mesozoic dyke swarms in southern Africa and their origin in the disruption of Gondwana. Journal of African Earth Sciences 30: 499-513.

Renard, V. \& Mascle, J., 1974, Eastern Atlantic continental margins; various structural and morphological types. In: Burk, C.-A \& Drake, C.-L (Editors), The geology of continental margins Springer-Verlag, New York, United States, pp. 285-291. 
Renne, P.R., Ernesto, M., Pacca, I.G., Coe, R.S. Glen, J.M., Prévot, M. \& Perrin, M. 1992. The Age of Paranà Flood Volcanism, Rifitng of Gondwanaland and the Jurassic-Cretaceous Boundary. Sciences, 258: 975-979.

Renne, P. R., Deckart, K., Ernesto, M., Féraud, G. \& Piccirillo, E. 1996. Age of the Ponta Grassa dike swarm Brazil, and implications to Parana flood volcanism. Earth and Planetary Science Letters 144: 199-211.

Reyre, D. 1966. Particularités géologiques des bassins côtiers de l'ouest Africain essai de recapitulation, In: Sedimentary basins of the African Coast, Symposium, Pt. 1: Paris, Union Internat. Soc. Géol., Assoc. Serv. Géol. Africains, p 253-304.

Rosendahl, B.R., Groschel-Becker, H., Meyers, J. \& Kaczmarick, K., 1991. Deep seismic reflection study of a passive margin, southeastern Gulf of Guinea. Geology 19: 291-295.

Rosendahl, B.R. \& Groschel-Becker, H., 1999. Deep seismic structure of the continental margin in the Gulf of Guinea: a summary report. In: Cameron, N. R., Bate R. H. \& Clure, V. S., (Editors), The oil and gas habitats of the South Atlantic, Geol. Soc. London, Spec. Publ. 153: $75-84$.

Sahabi, M. 1993. Modèle général de l'évolution de l'océan Indien. Brest, Univ. de Bretagne Occidentale: 187 p vol. 1 et 243 p vol. 2.

Sahabi, M., Aslanian, D. \& Olivet, J.-L. 2004. Un nouveau point de départ pour l'histoire de I'Atlantique Central. Compte Rendus Geosciences 33: 1041-1052.

Sandwell, D. T. \& Smith, W.H.F. 1997. Marine gravity anomaly from Geosat and ERS-1 satellite altimetry. Journal of Geophysical Research 102: 10039-10054.

Schettino, A. \& Scotese, C.R., 2005. Apparent polar wander paths for the major continents 200Ma to the present day: a paleomagnetic reference frame for global plate tectonic reconstructions. Geophys. J. Int. 163: 727-759.

Schmitt, A. K., Emmermann, R., Trumbull, R.B., Buhn, B. \& Henjes-Kunst, F., 2000. Petrogenesis and 40Ar/39Ar geochronology of the Brandberg complex, Namibia: evidence for a major mantle contribution in metaluminous and peralkaline granites. J. Petrol. 41:12071239

Schreckenberger,

B. http://www.bgr.bund.de/cln_030/nn_466886/DE/Themen/MeerPolar/Meeresforschung/Projek te__und_Beitraege/SAfrika/FB__Seemagnetik_BOSA/Seemag_Inhalt.html.

Sibuet, J. C., \& Mascle, J., 1978. Plate kinematic implications of the Atlantic Equatorial fracture zone trends. Journal of Geophysical Research 83: 3401-3421.

Sibuet, J.C., Hay, W. H., Prunier, A., Montadert, L., Hinz, K \& Fritsch, J. 1984. Early Evolution of the South Atlantic Ocean : Role of the Rifting Episode. Initial Reports Of DSDP $75,469-481$.

Smith, A.G. \& Briden, J.C., 1977. Mesozoic and Cenozoic paleo-continental maps. Cambridge Univ. Press., Cambridge, 52 maps, 63 pp.

Srivastava, S.P. \& Roest, W.R., 1999. Extent of oceanic crust in the Labrador Sea. Marine and Petroleum Geology, v, 16, p. 65-84.

Stewart, K., Turner, S., Kelley, S., Hawkesworth, C., Kirstein, L. \& Mantovani, M. 1996. 3-D, 40Ar-39Ar geochronology in the Paranà continental flood basalt province. Earth and Planetary Science Letters 143: 95-109.

Sykes, L. R., 1978. Intraplate Seismicity, Reactivation of Preexisting Zones of Weakness, Alkaline Magmatism, and Others Tectonism Postdating Continental Fragmentation. Reviews of Geophysics and Space Physics 1: 621-683.

Szatmari, P.J., Milani, E.J., Lana, M.C., Conceicao, J.C.J. \& Lobo, A.P., 1985. How South Atlantic rifting affects Brazilian oil reserves distribution. Oil Gas Journal 83: 107-113.

Szatmari, P., Batista, J., Francolin, L., Zanotto, O. \& Wolff S., 1987. Evoluçao Tectônica da margem equatorial brasileira. Revista brasileira de Geociências, 17 (2): 180-188.

Szatmari, P. \& Milani, E.J., 1999. Microplate rotation in northeast Brazil during South Atlantic rifting: analogies with the Sinai microplate. Geology, v. 27, n. 12, p. 1115-1118.

Sykes, L. R., 1978. Intraplate Seismicity, Reactivation of Preexisting Zones of Weakness, Alkaline Magmatism, and Other Tectonism Postdating Continental Fragmentation. Reviews of Geophysics and Space physics 4: 621-683. 
Talwani, M. \& Eldholm, O., 1977. Evolution of the Norwegian-Greenland Sea. Geological Society of America Bulletin, 88: 969-999.

Talwani, M. \& Abreu, V., 2000. Inferences regarding initiation of oceanic crust formation from the U.S. East Coast margin and conjugate South Atlantic margins. In: W. U. Mohriak and M. Talwani (eds.), Atlantic rifts and continental margins, AGU Geophysical Monograph 115, p. 211-233.

Tello Saenz, C.A., Hackspacher, P.C., Hadler Neto, J.C., lunes, P.J., Guedes, S., Ribeiro, L.F.B. \& Paulo, S.R. 2003. Recognition of Cretaceous, Paleocene, and Neogene tectonic reactivation through apatite fission-track analysis in Precambrian areas of southeast Brazil: association with the opening of the south Atlantic Ocean. Journal of South American Earth Sciences 15: 765-774.

Thomaz Filho, A., Cesero, P., Mizusaki, A. M. P., Leão, J. G., 2005. Hotspot volcanic tracks and their implications for South American Plate motion, Campos Basin (Rio de Janeiro State), Brazil. Journal of South America Earth Science, 18, 383-389.

Torsvik, T.H., Rousse, S., Labails, C., \& Smethurst, M.A., 2009. A new scheme for the opening of the South Atlantic Ocean and the dissection of an Aptian salt basin. Geophysical Journal International, doi:10.1111/j.1365-246X.2009.04137.x

Trompette, R., 1994. Geology of Western Gondwana 2000-500 Ma: Pan-African-Brasiliano Aggregation of South America and Africa. A. A. Balkema, Rotterdam, Brookfeild, pp. 350.

Turner, S., Regelous, M., Kelley, S., Hawkesworth, C. \& Mantovani, M. 1994. Magmatism and continental break-up in the South Atlantic high precision ${ }^{40} \mathrm{Ar}-{ }^{39} \mathrm{Ar}$ geochronology.. Earth and Planetary Science Letters 121: 333-348.

Unternher, P., 1982. Etude Structurale et cinématique de la mer de Norvège et du Groenland - Evolution du microcontinent de Jan Mayen. Ph. D. Thesis, Univ. de Bretagne Occidentale, Brest, $228 \mathrm{pp}$.

Unternher, P., Curie. D., Olivet, J.L., Goslin J. and Beuzart P. 1988. South Atlantic fits and intraplate boundaries in Africa and South America. Mesozoic and Cenozoic Plate Reconstruction. C. R. S. Scotese, W. W., Tectonophysics 155: 169-179.

Urien, C. M. \& Zambrano, J. J. 1973. The geology of the basins of the Argentine continental margin and the Malvinas Plateau. In: Nairn, A E M and Stehli, F G (Editors), The Ocean Basins and Margins, 1: the South Atlantic. Plenum press, New York.

Vink, G. E. 1982. Continental rifting and the implications for the plate tectonic reconstructions. Journal of Geophysical Research 87: 10677-10688.

Vogt, P.R., Anderson, C.J., \& Bracey, D.R. 1973 Mesozoic magnetic anomalies, seafloor spreading and geomagnetic reversals in the southwestern North Atlantic, J. Geophys. Res. 76 20, 4796-4823.

Watkins, R.T., McDougall, I. \& Le Roex, A. P., 1994. K-Ar ages of the Brandberg and Okenyenya igneous complexes, north-western Namibia. Geol. Rundsch. 83: 348-356.

Watt, W. S. 1969. Coast parallel dike-swarm of southwest Greenland in relation to the opening of the Labrador Sea. J. Earth Sci. Can. 6: 1320-1321.

White, R.S., 1992. Crustal structure and magmatism of North Atlantic continental margins. Journal of the Geological Society of London, v. 149, p. 841-854.

Zalán P. V. \& de Oliveira J. A. B., 2005. Origem e evolução estrutural do Sistema de Riftes Cenozóicos do Sudeste do Brasil. B. Geoci Petrobras, Rio de Janeiro, 13, n²: 269-300

Zalán, P. V., 2004. Evolução fanerozóica das bacias sedimentares brasileiras. In V. Mantesso-Neto, A. Bartorelli, C.D.R. Carneiro \& B. B. Brito-Neves (Coords.), Geologia do continente sul-americano. Evolução da obra de Fernando Flávio Marques de Almeida, São Paulo: Ed. Beca: 245-263.

Zalán, P.V., Wolff, S., Conceição J.C.J. Astolfi, M.A.M., Vieira, I.S., Appi, V.T., Neto, E.V.S., Cerqueira, J.R., Marques, A., 1990. The Paraná Basin, Brazil. In: Leighton, M.W., Kolata, D.R., Oltz D.F. and Eidel, J.I. (Editors), Interior Cratonic Basins: AAPG Memoir, 51, 8, 81708.

Zambrano, J.J. \& Urien, C.M., 1970. Geological outline of the basins in southern Argentina and their continuation off the Atlantic. Journal of Geophysical Research 758: 1363-1369. 
Figures 


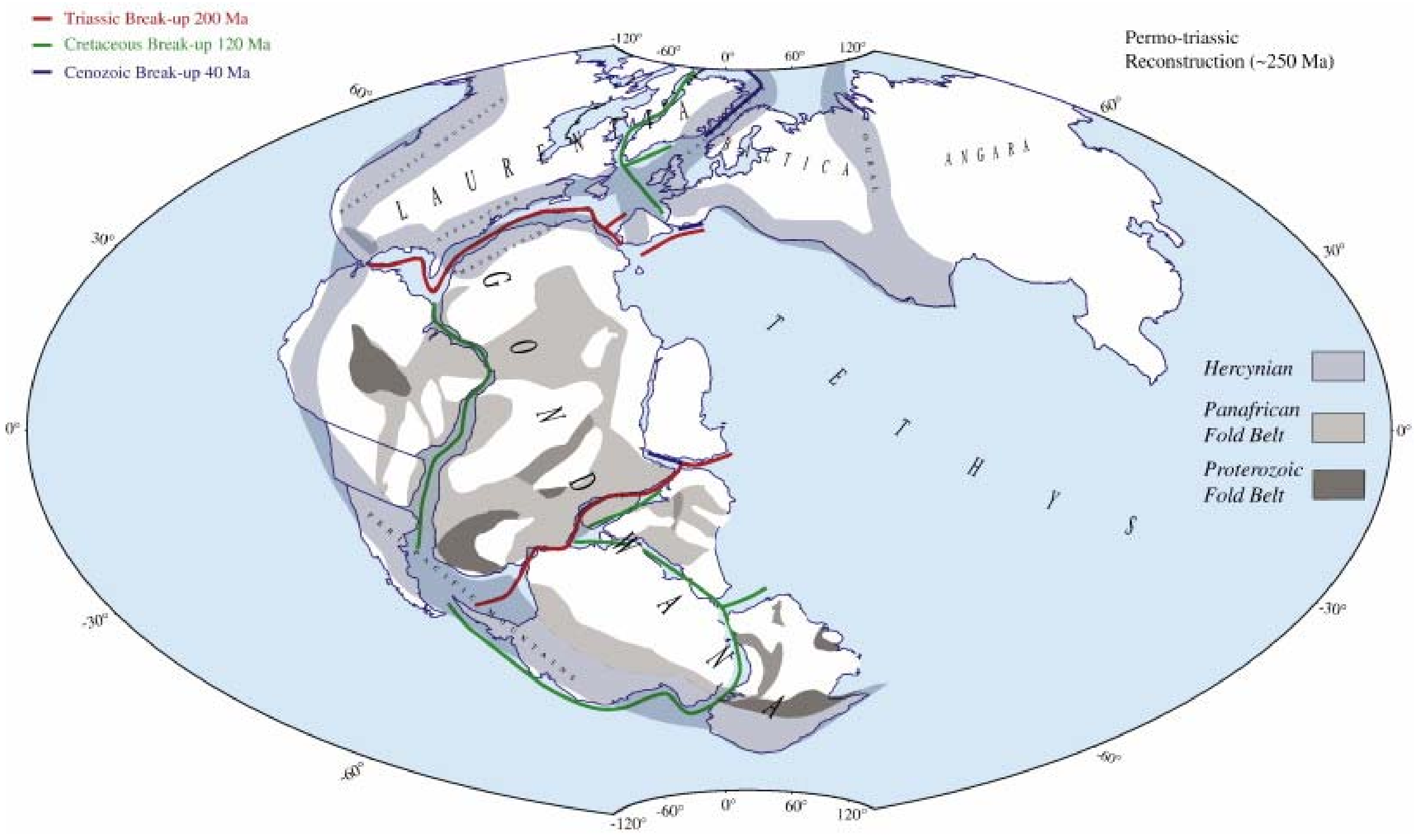


Figure 1: Reconstruction at Permo-triassic time ( $250 \mathrm{Ma})$ (Olivet \& Aslanian, pers. comm.) just before the break-up of the mega-continent Pangea. This break-up occurred in three main episodes separated by about $60 \mathrm{Ma}$. The Upper Triassic episode (in red, about 200-190 Ma) separated the Pangea in three equivalent blocks (Laurussia, Africa and South America, Madagascar, India, Antarctica and Australia). The second episode (in green) occurred during the Early Cretaceous (about 133-120 Ma), and the last episode (in blue) during the Tertiary (60 Ma: chron). Note the almost general coincidence between the different break-ups and older orogenic belts (Hercynian - Panafrican and Proterozoic). Hammer Projection. 


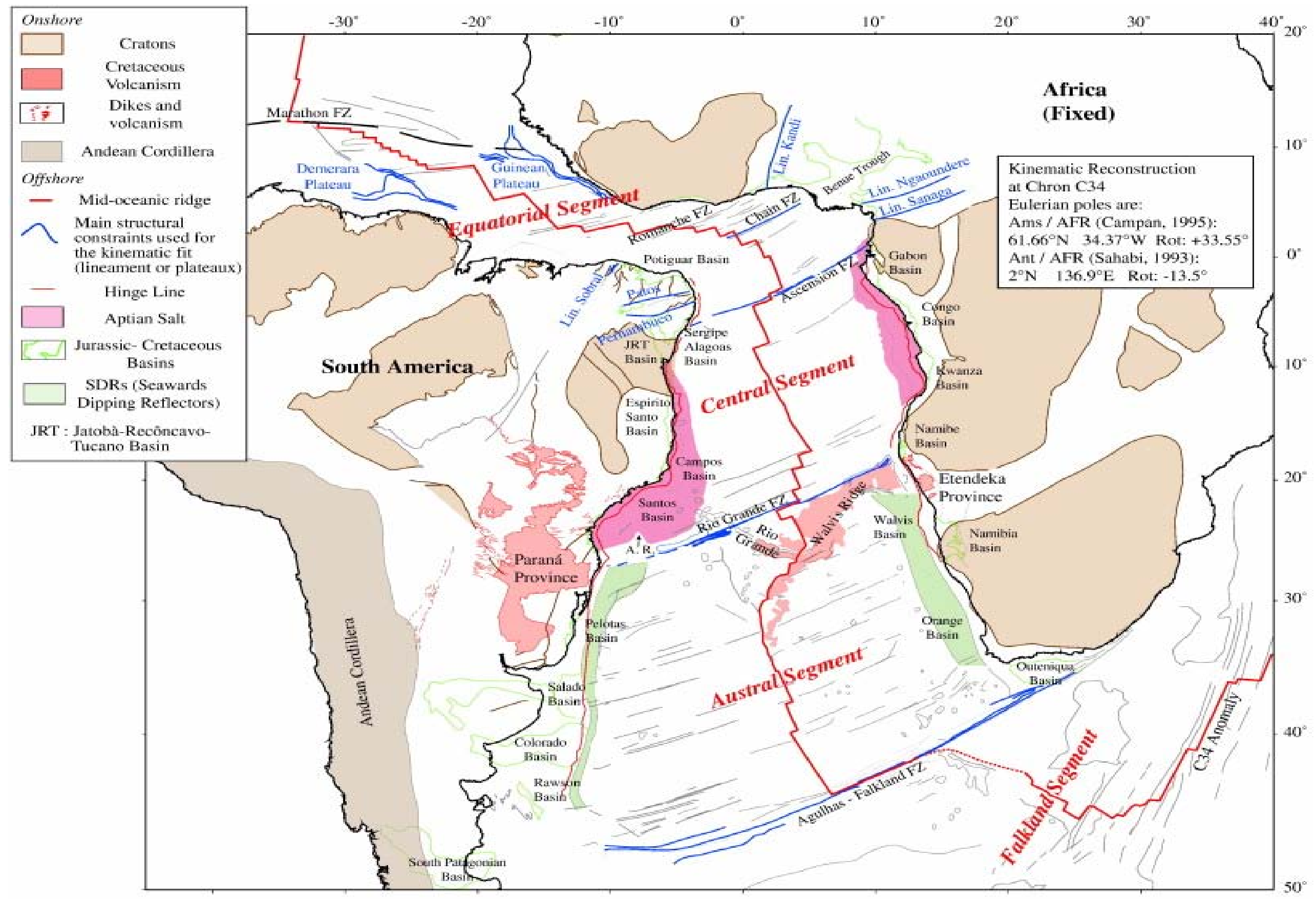


Figure 2: General tectono-structural map of the South Atlantic Ocean at Chron 34 (84 Ma). For this well-constrained reconstruction, we used the Eulerian pole from Campan (1995) for the Equatorial and South Atlantic oceans and the Eulerian pole from Sahabi (1993) for the South Western Indian Ocean. This figure summarizes all the geological structures that will be used in this study. Fracture zones and seamounts are based on interpretation of satellite derived gravity $1 \mathrm{mn} \times 1 \mathrm{mn}$ grid (Sandwell \& Smith, pers. comm.). The bathymetric contours near Walvis Ridge are based on the Ifremer detailed bathymetric map (Needham et al., 1986). The large red line represents the accreting oceanic ridge at Chron 34. Sedimentary Cretaceous basins are represented by green lines (after Choubert et al., 1968; Almeida et al., 1970; Urien \& Zambrano, 1973; Hinz, 1999; Turner et al., 1994; Trompette, 1994). Cratons are represented by brown lines (after Trompette, 1994). Aptian salt extension (pink areas) are based on a compilation of different sources (Pautot et al., 1973; Renard \& Mascle, 1974; Emery et al., 1975; Lehner \& De Ruiter, 1977; Rosendahl et al., 1991; Rosendahl \& Groschel-Becker, 1999; Meyers et al., 1996; Marton et al., 2000; Contrucci et al., 2004; Moulin et al., 2005 for the African side, and Butler, 1970; Mascle \& Renard, 1976; Leyden et al., 1976 in Curie, 1984; Heilbron et al., 2000; Unternehr,. pers. comm.. for the Brazilian side). The location of the Abimael ridge (interpreted by Mohriak, 2001, as an aborted oceanic propagator across the Rio Grande Fracture Zone) is given by the letters A. R. with a black arrow. Seaward Deeping Reflectors (SDRs) (green light areas) are from Gondcalves da Souza (1991) and Moulin et al. (2006) for South America, and Bauer et al. (2000) for Africa. The M-sequences magnetic anomalies are based on our new interpretation (see Fig. 4 and 5), whereas the C34 anomaly is based on the interpretation of Klitgord \& Schouten (1986). The main structural constraints (lineaments and plateau limits) used for the kinematic reconstructions (blue lines) are drawn according to Gouyet (1988), Choubert et al. (1968), Gueguen (1995), Almeida et al. (1970) and Curie (1984). Cretaceous volcanism (in red) and triassic volcanism (in purple) limits are by Almeida et al. $(1970$, ) Jacques (2003a; 2003b), Turner et al. (1994), Araujo et al. (2000), Marzoli et al. (1999a) and Choubert et al. (1968). Hinge lines (thick red lines) are based on the compilation of the interpretation of Unternehr (comm. pers.), Heilbron et al. (2000), Karner \& Driscoll (1999) and Moulin et al. (2006). Mercator projection. 

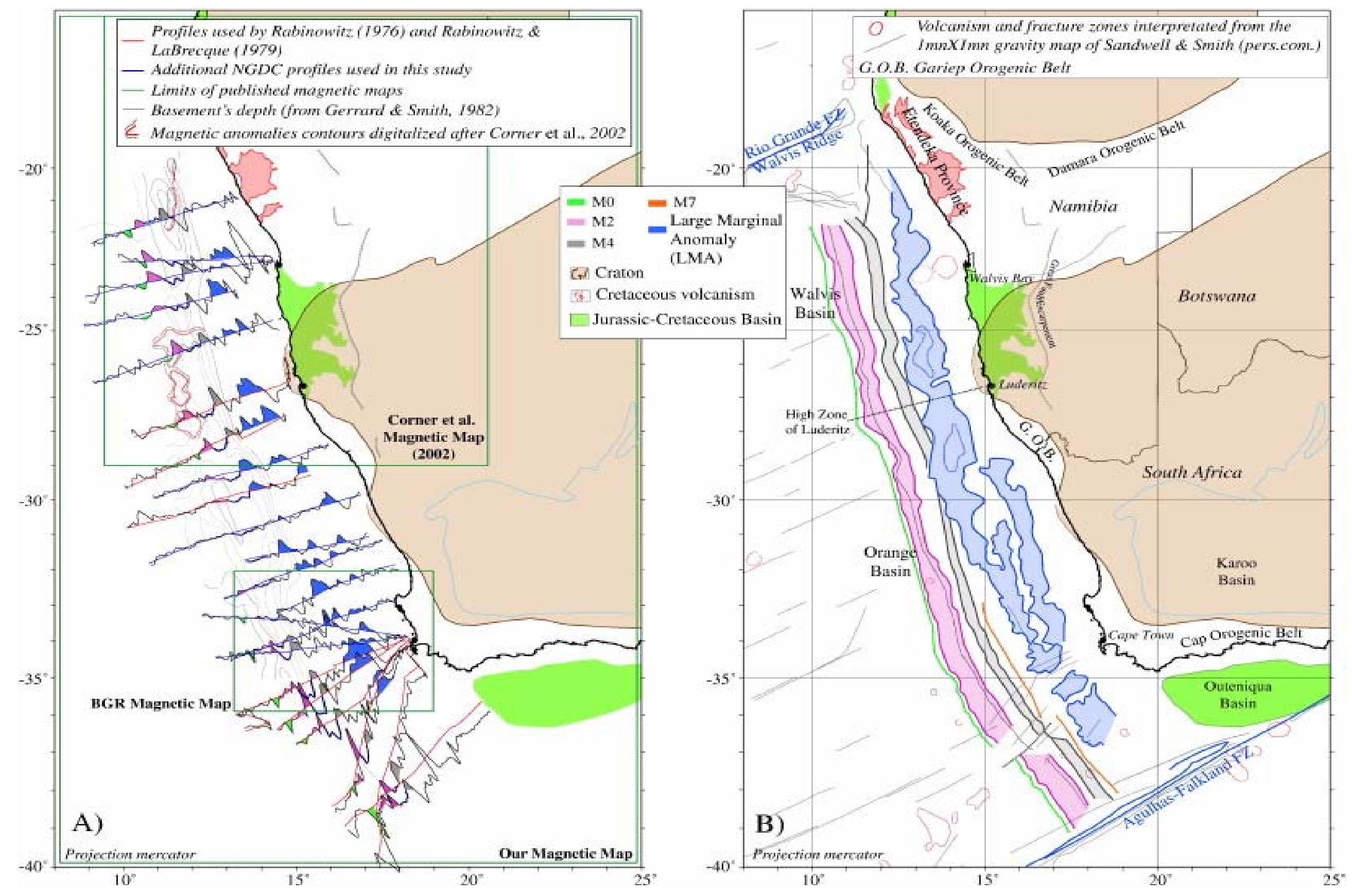
Figure 3: General magnetic map of the southern segment of the South Atlantic Ocean (African side). A) data control of selected magnetic profiles (in red, profiles used by Rabinowitz and LaBrecque, 1979 and Rabinowitz, 1976; in blue, additional profiles of NGDC data base) and magnetic maps (green boxes) used for the Mesozoic magnetic anomaly interpretation between $40^{\circ} \mathrm{S}$ and $20^{\circ} \mathrm{S}$ (Corner et al., 2002; BGR (site web: //www.bgr.bund.de, contact Dr. B. Schreckenberger), and our grid based on NGDC database). B) Our new Mesozoic magnetic sequence interpretation. The black line in the pink area (magnetic anomaly M2) corresponds to the maximum amplitude of the anomaly. The eastern edge of the prominent Large Magnetic Anomaly (LMA - in blue - see details in the text) corresponds to the $G$ anomaly of Rabinowitz and LaBrecque (1979). Same geological structure legends as in Figure 2. Mercator projection. 


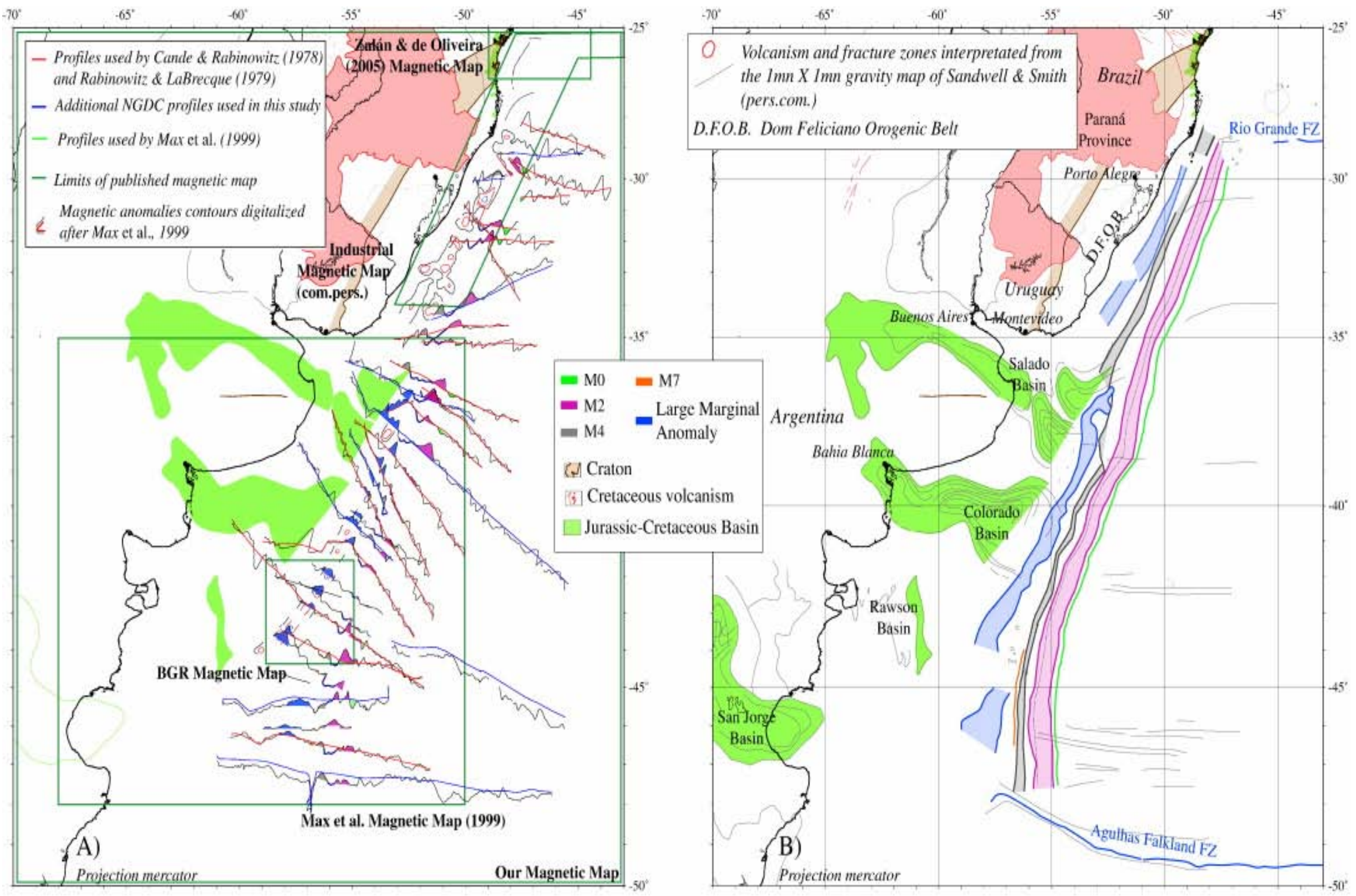


Figure 4: General magnetic map of the South Segment of the South Atlantic Ocean (South American side). A) data control of selected magnetic profiles (in red, profiles used by Rabinowitz \& LaBrecque, 1979 and Cande \& Rabinowitz, 1978; in green, profiles used by Max et al., 1999 and in blue, additional profiles of NGDC data base) and magnetic maps (green boxes) used for the Mesozoic magnetic anomalies interpretation between $50^{\circ} \mathrm{S}$ and $25^{\circ} \mathrm{S}$ (Max et al., 1999, BGR, (site web: //www.bgr.bund.de, contact Dr. B. Schreckenberger); Industrial Magnetic map, pers. comm., Zalan \& de Oliveira, 2005, and our grid based on NGDC database) B) Our new Mesozoic magnetic sequence interpretation. The black line in the pink area (magnetic anomaly M2) corresponds to the maximum amplitude of the anomaly. The western edge of the prominent Large Magnetic Anomaly (LMA - in blue - see details in the text) corresponds to the $G$ anomaly of Rabinowitz and LaBrecque (1979). Same geological structure legends as in Figure 2. Mercator projection. 
Synchronous and diachronous Models

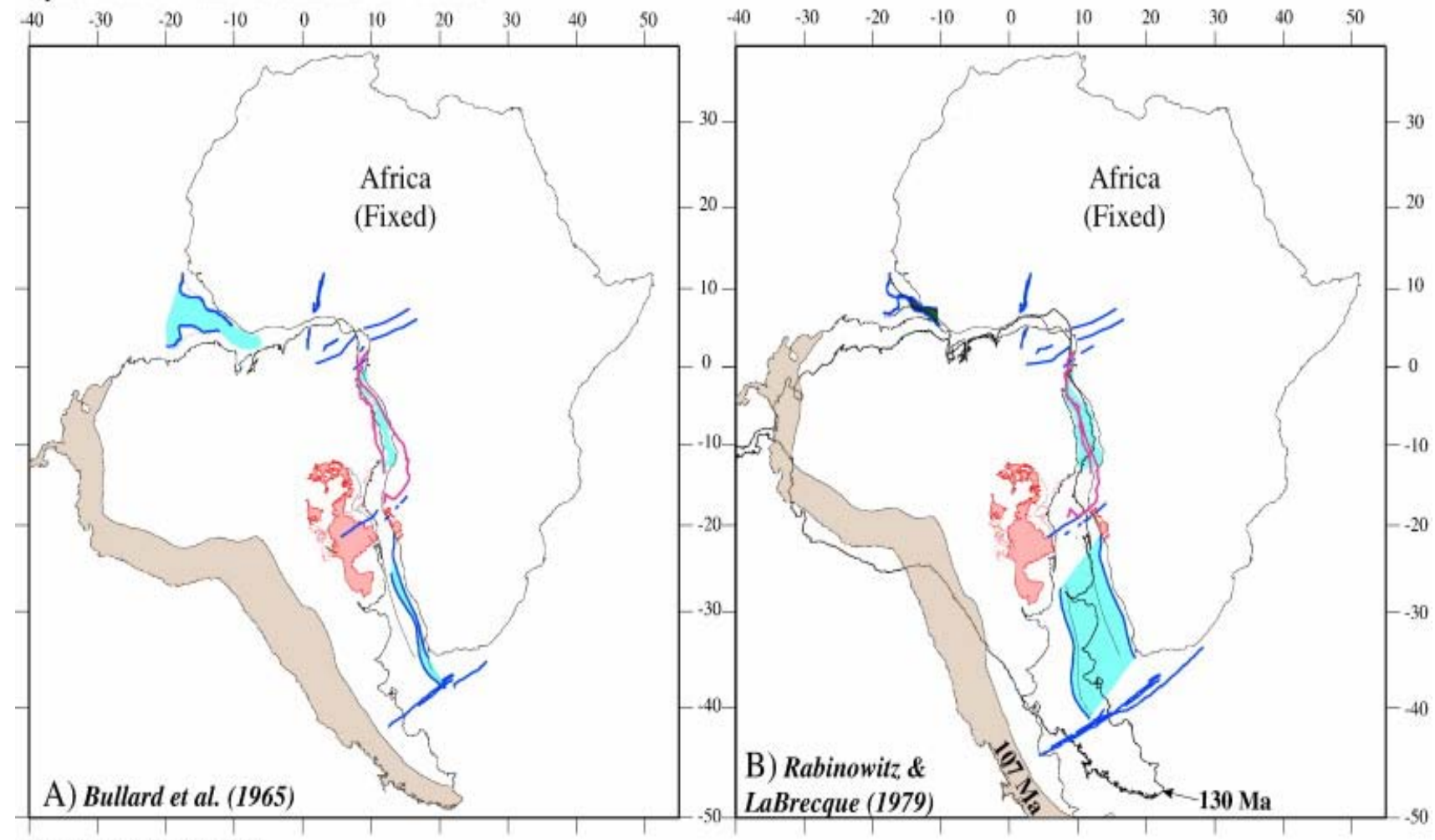

Propagation Model
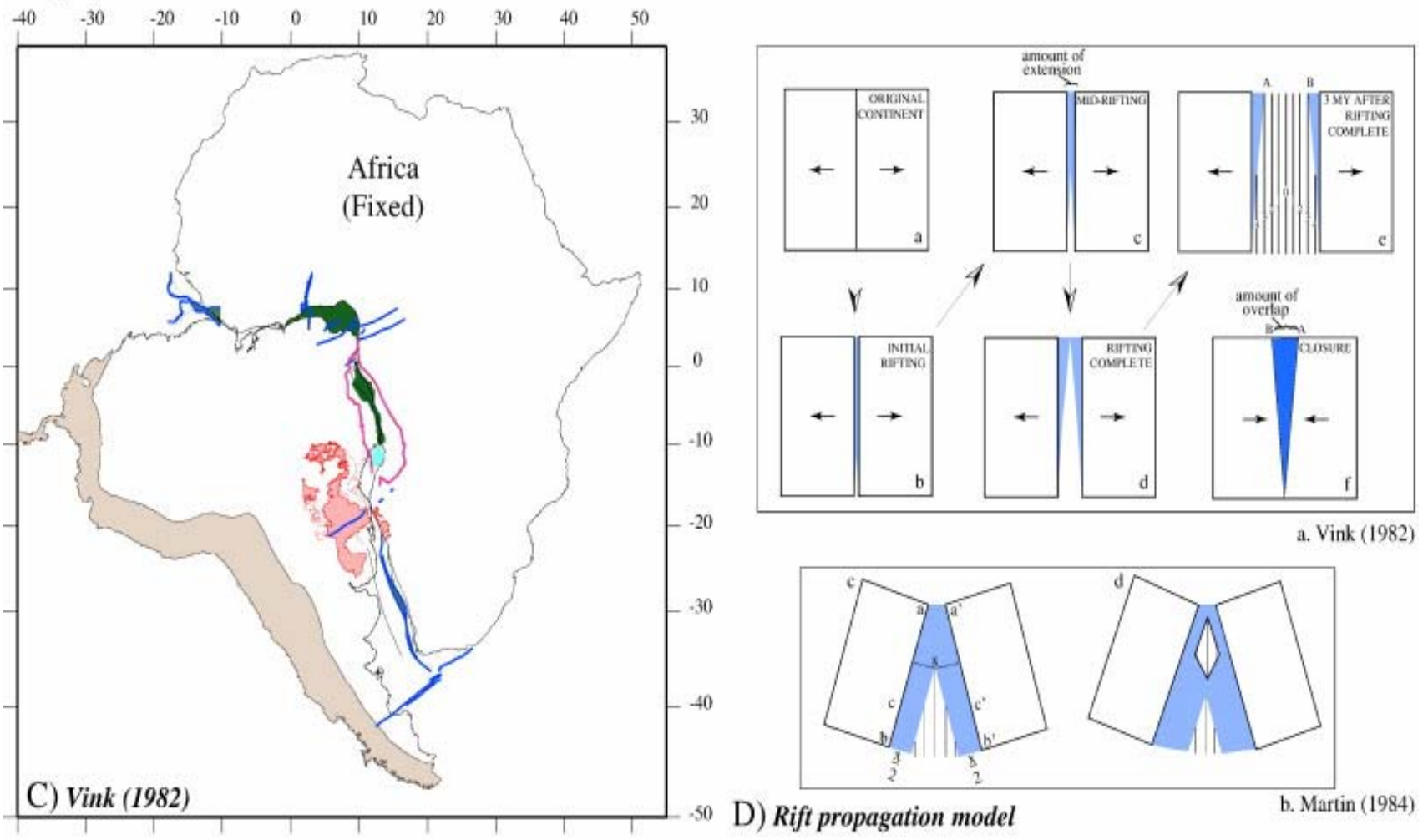

D) Rift propagation model

Overlap $\square$ Gap - Salt $\quad$ Cretaceous Dikes and volcanism $\square$ Andean Cordillera

Main structural constraints

Figure 5: The first four « rigid » models, with the constraints used in this study. The West Africa block is considered as the fixed plate. Overlaps between the hinge lines are in green, gaps in blue. A) The first computer-assisted statistical reconstruction (Bullard et al., 1965) shows a good fit in the southern part of the South Atlantic Ocean but has dramatic 
consequences in the Equatorial Atlantic Ocean (huge gap between Demerara and Guinea plateaus) This illustrates the impossibility to close together the Equatorial and South Atlantic oceans. B) Rabinowitz \& LaBrecque (1979) proposed a model with 2 phases, at the Anomaly G (130 Ma according to the scale from Larson \& Hilde, 1975, used by Rabinowitz \& LaBrecque in 1979; $139.5 \mathrm{Ma}$ after the scale of Gradstein et al., 2004) and at $107 \mathrm{Ma}$ (Late Aptian from Rabinowitz \& LaBrecque, 1979, or $112 \mathrm{Ma}$ after the scale of Gradstein et al., 2004). During the first phase, this model implies the same dramatic consequences in the Equatorial Ocean. C) The « propagating » model of Vink, 1982. This model presents an important overlap of the hinge lines in the central segment. D) Two sketches for propagating models proposed by Vink (1982) and Martin (1984). Note that the magnetic anomalies are oblique to the margins. See details in the text. Same geological structure legends as in Figure 2. Mercator projection. See Table 1 for the Eulerian poles used in this figure. 
African intraplate deformation

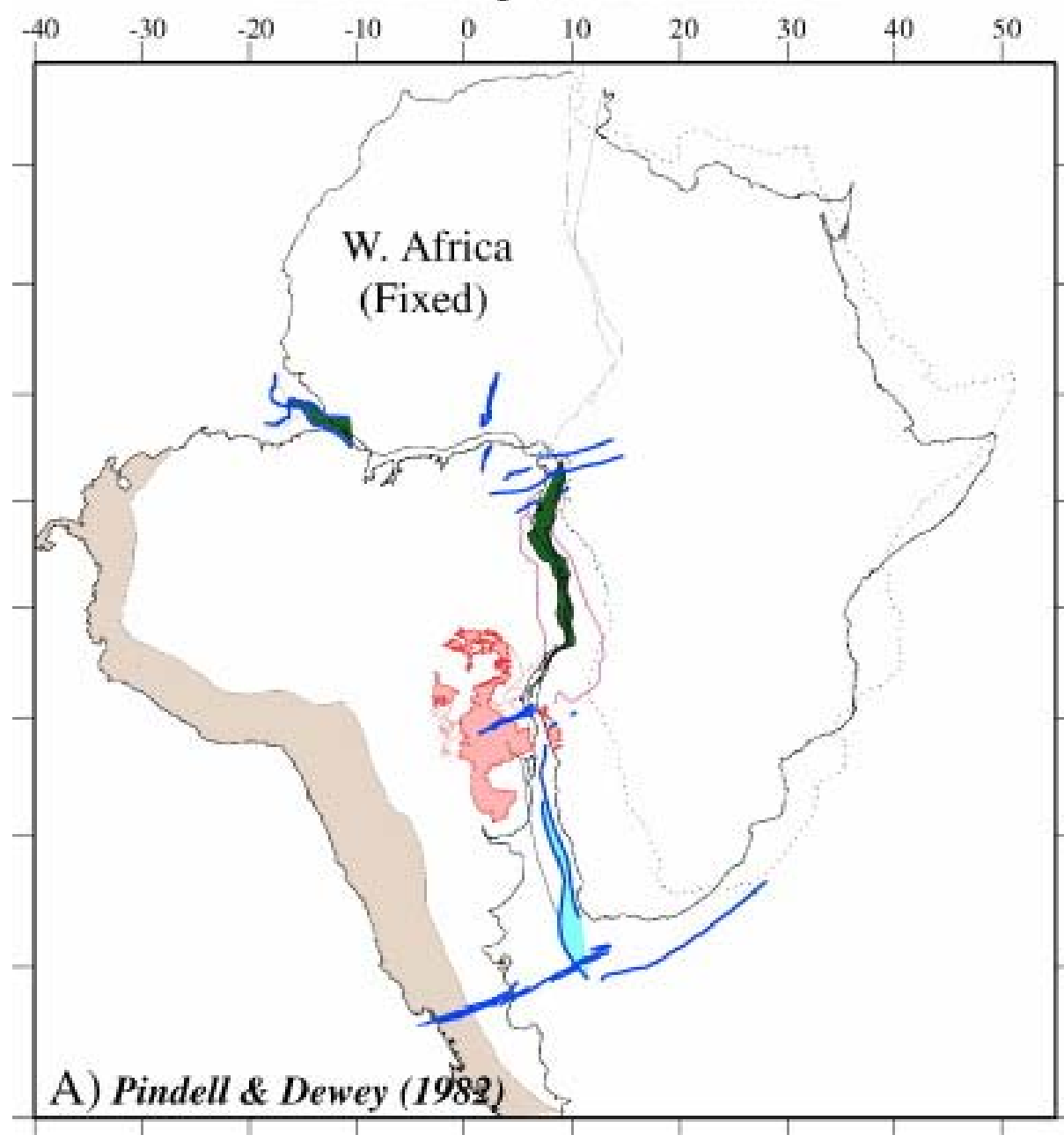

African and South American intraplate deformation

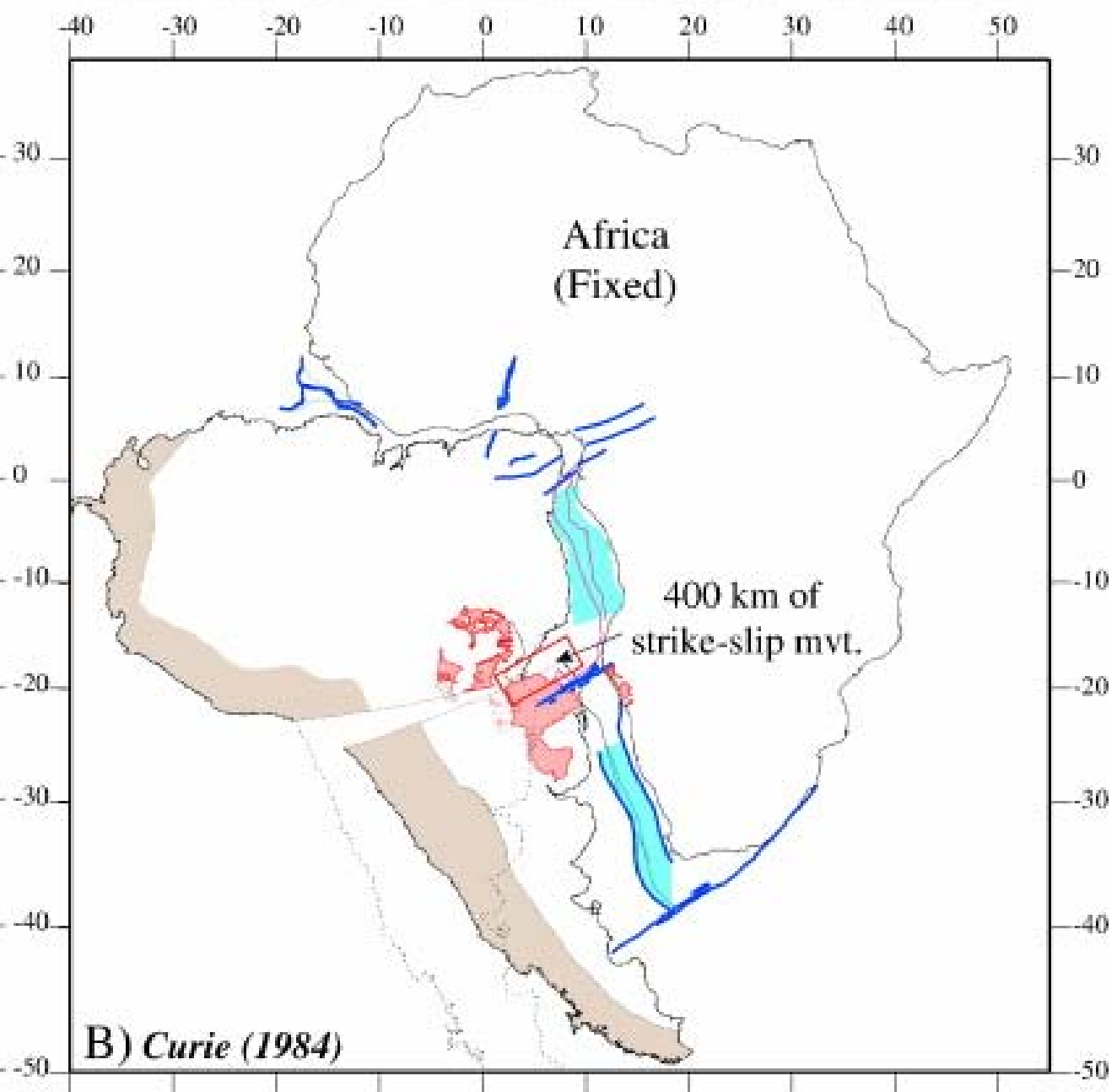

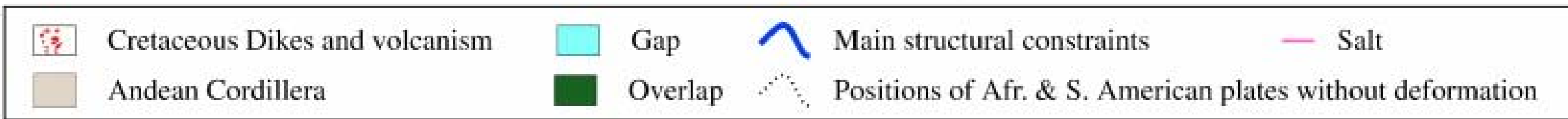


Figure 6: The first non-rigid models. The West Africa block is considered as the fixed plate. Overlaps between the hinge lines are in green, gaps in blue. A) The first non-rigid Africa reconstruction (Pindell \& Dewey, 1982). These authors followed the assumption of Burke \& Dewey (1974) and included intra-plate deformation in the Africa plate, especially in the Benue Basin. This reconstruction implies compressive motion in the South Sudan Rift and important overlap of the Equatorial plateaus and of the hinge lines in the central Segment. B) The first non-rigid South America model (Curie, 1984). Both Equatorial Ocean and the southern segment are closed simultaneously. This model implies a $400 \mathrm{~km}$ strike-slip movement in the Paraná basin. Same geological structure legends as in Figure 2. Mercator projection. See Table 1 for the Eulerian poles used in this figure. 


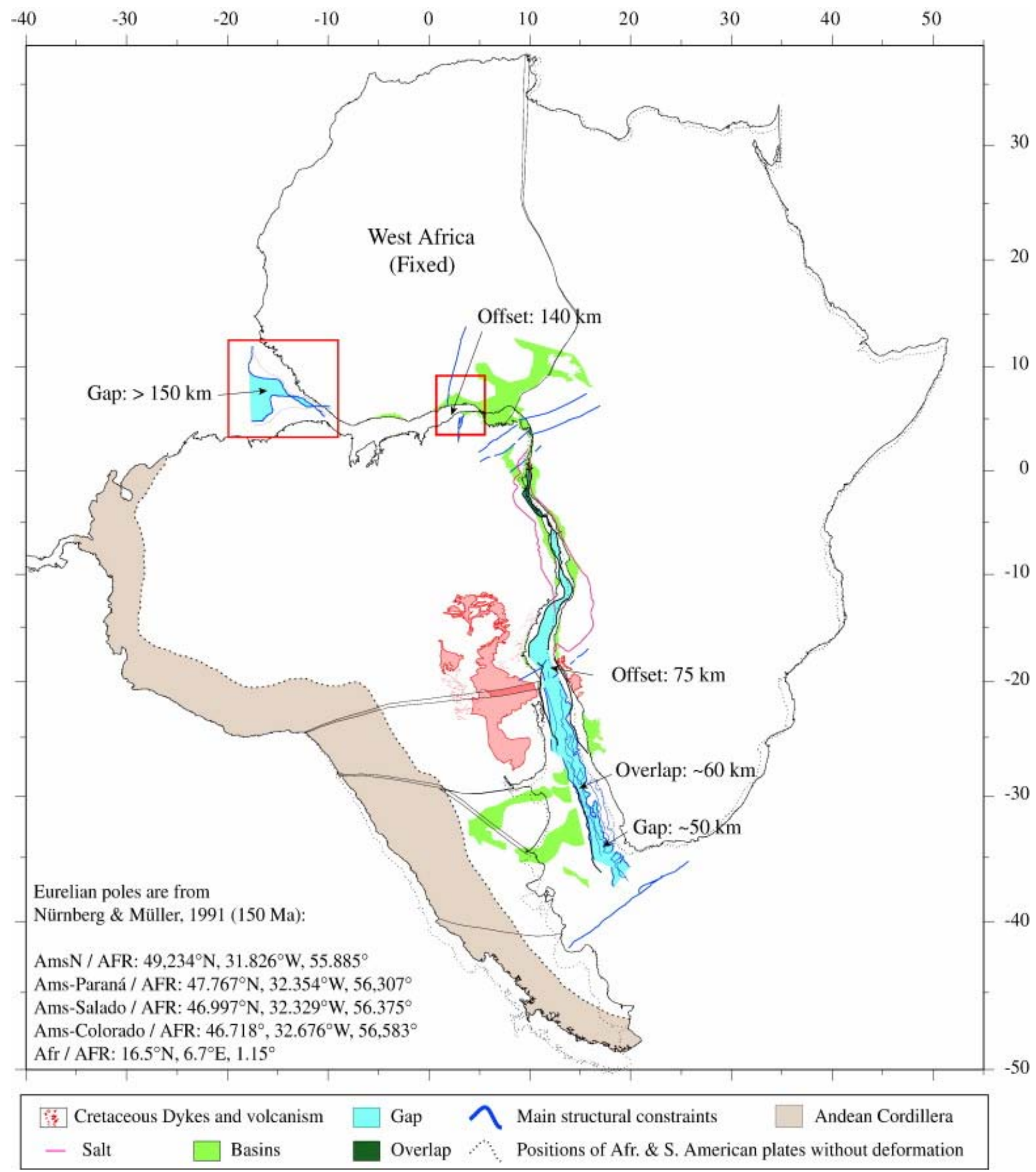

Figure 7: Pre-drift reconstruction of Nürnberg \& Müller (1991) at 150 Ma (Tithonian, 150.8 according to Gradstein et al., 2004). The West Africa block is considered as the fixed plate. Overlaps between the hinge lines are in green, gaps in blue. Following Curie (1984) and Unternehr et al. (1988), these authors proposed a model with both African (Benue Trough and Niger Rift) and South American (Colorado, Salado and Paraná basins) acceptable intraplate deformations. This model shows overlap in the northern part of the Central Segment (South-Gabon / Sergipe basins) and of the LMA (more than $50 \mathrm{~km}$ ) between $28^{\circ} \mathrm{S}$ and $30^{\circ} \mathrm{S}$. It implies a gap between the Demerara and Guinea plateaus of more than $150 \mathrm{~km}$ and an offset between the Kandi and Sobral conjugate lineaments of $140 \mathrm{~km}$. The Rio Grande 
Fracture Zone (FZ) presents an offset of $75 \mathrm{~km}$. Same geological structure legends as in Figure 2. Mercator projection. See Table 1 for the Eulerian poles used in this figure.
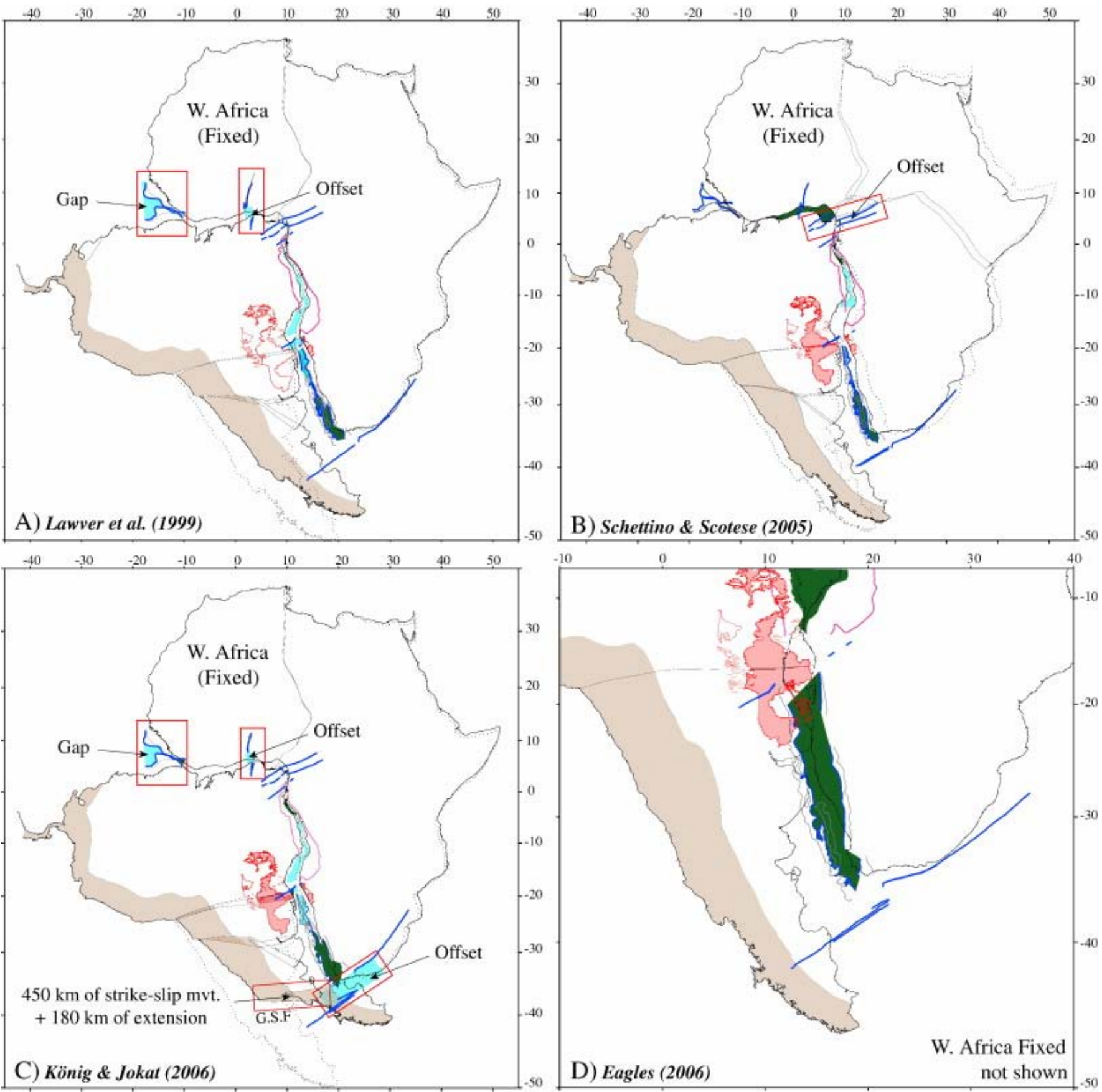

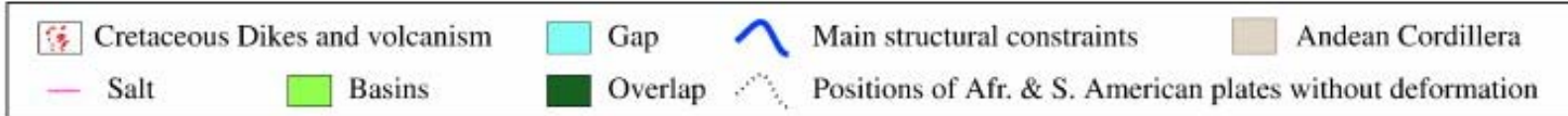

Figure 8: Four last pre-rift reconstructions published in the last 10 years. The West Africa block is considered as the fixed plate. Overlaps between the hinge lines are in green, gaps in blue. A) The model of Lawver et al. (1999) is issued from the international PLATES project (University of Texas, http://www.ig.utexas.edu/research/projects/plates). It presents, in the Equatorial and Central Segments, a configuration equivalent to that of Nürnberg \& Müller (1991) with the same unacceptable misfits. In the Austral Segment, the LMAs show an overlap of $150 \mathrm{~km}$, and the Rio Grande fracture zones an offset of more than $100 \mathrm{~km}$. B) The model of Schettino and Scotese (2005) is based on the synthetic apparent polar wander 
(APW) paths for major continents (North America, South America, Eurasia, India, Central Africa, Australia and Antarctica) for the last $200 \mathrm{Ma}$. It presents a very important overlap of the coastline in the vicinity of the Niger Delta. C) The reconstruction of König \& Jokat (2006) at Jurassic Quiet Magnetic Zone (JQMZ). As that of Lawver et al. (1999) presents, in the Equatorial and Central Segments, a configuration equivalent to that of Nürnberg \& Müller (1991) with the same unacceptable misfits. It implies important intra-plate deformations (450 km-dextral strike-slip movement in the Gastre System fault (G.S.F.) and extension of $150 \mathrm{~km}$ in the Salado Basin). The LMA anomalies present an important overlap (between 230 and $350 \mathrm{~km}$ in the southern part of the Austral Segment) and the Falkland FZs, an offset of 300 $\mathrm{km}$. D) The reconstruction of Eagles (2006) at $150 \mathrm{Ma}$, is based on the northward propagation of the opening and the fit of the fracture zones, south of $20^{\circ} \mathrm{S}$. The author supposes the presence of intra-plate deformations inside South America, but gives only the Eulerian pole from the movement between the southern part of the South America and the Africa plates; we can therefore only present a zoom on the Austral segment. In this segment, LMA anomalies show a dramatic overlap. Same geological structure legends as in Figure 2. Mercator projection. See Table 1 for the Eulerian poles used in this figure. 


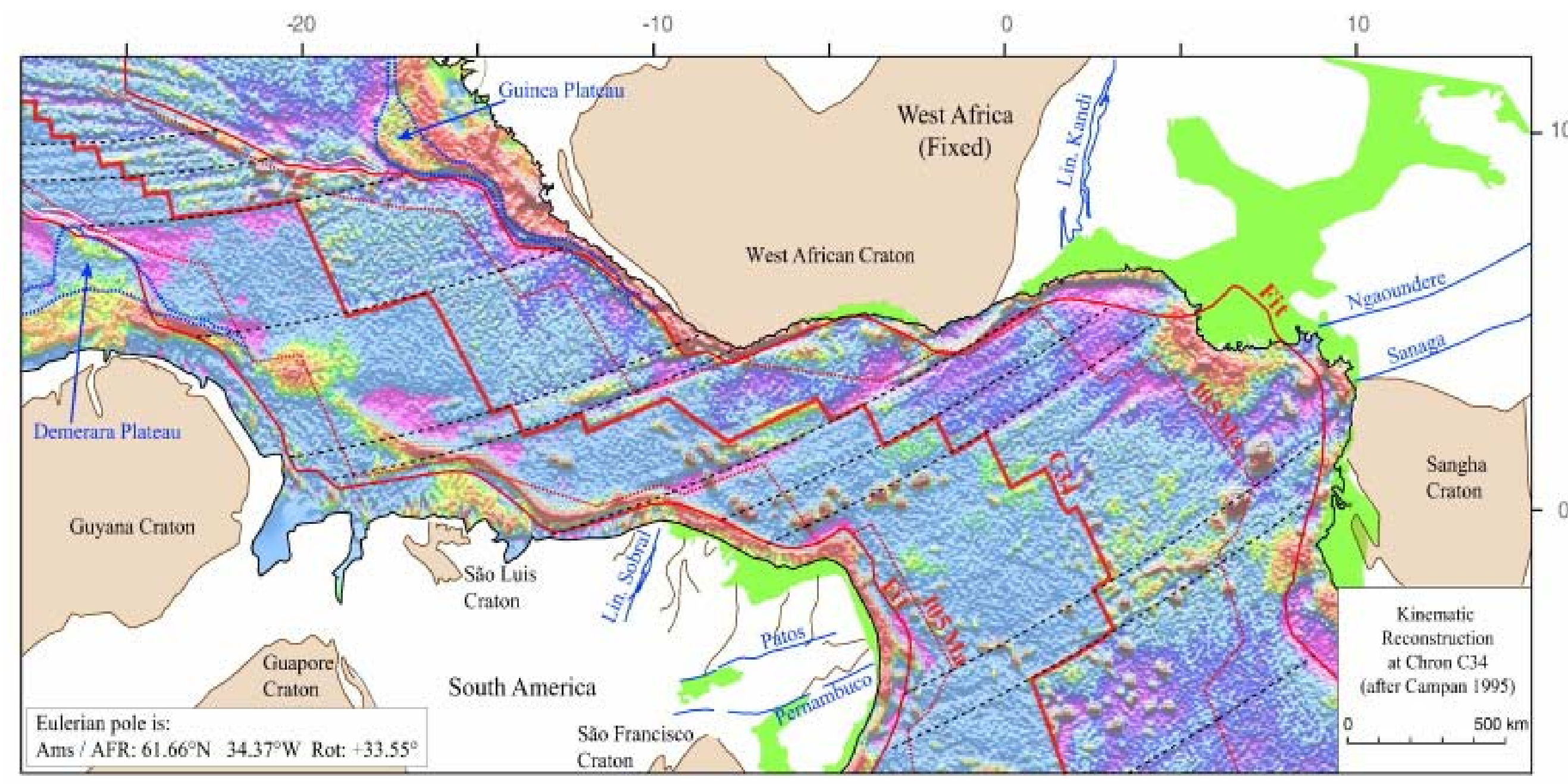

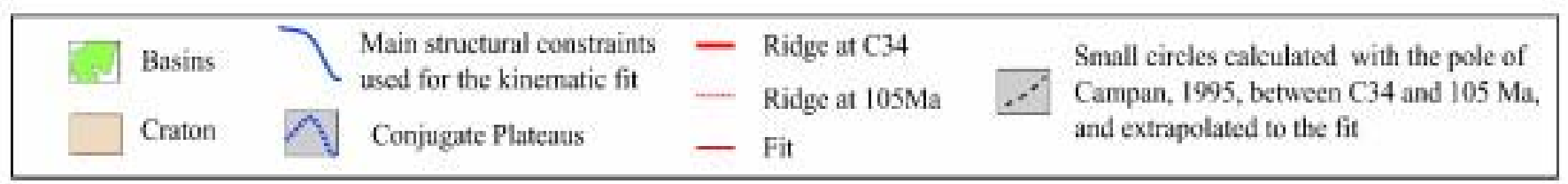


Figure 9: Kinematic reconstruction at Chron $34(84 \mathrm{Ma})$ of the Equatorial Atlantic Ocean. The figure shows, on each plate, the gravity data from Sandwell \& Smith (1997) between the coast and the anomaly C34. The Africa Plate, and its attached gravity grid, is fixed; the South American plate and gravity grid have been rotated with the Eulerian pole from Campan (1995). Note the perfect alignment of the FZs. The heavy red line represents the accreting ridge at that time, the thin red lines, the first accreting ridge before the breakup and the dotted red lines, the ridge at $105 \mathrm{Ma}$. The black dotted lines represent the small circles (relative movement between the Africa and America plates) calculated with the intermediate pole between C34 and $105 \mathrm{Ma}$ (Campan, 1995), extrapolated to the fit. Note the very good fit between these small circles and the fracture zones, which indicates that no change in movement direction occurs between $\mathrm{C} 34$ and the fit. The West Africa block is considered as the fixed plate. Same geological structure legends as in Figure 2. Mercator projection. See Table 2 for the Eulerian poles used in this figure. 


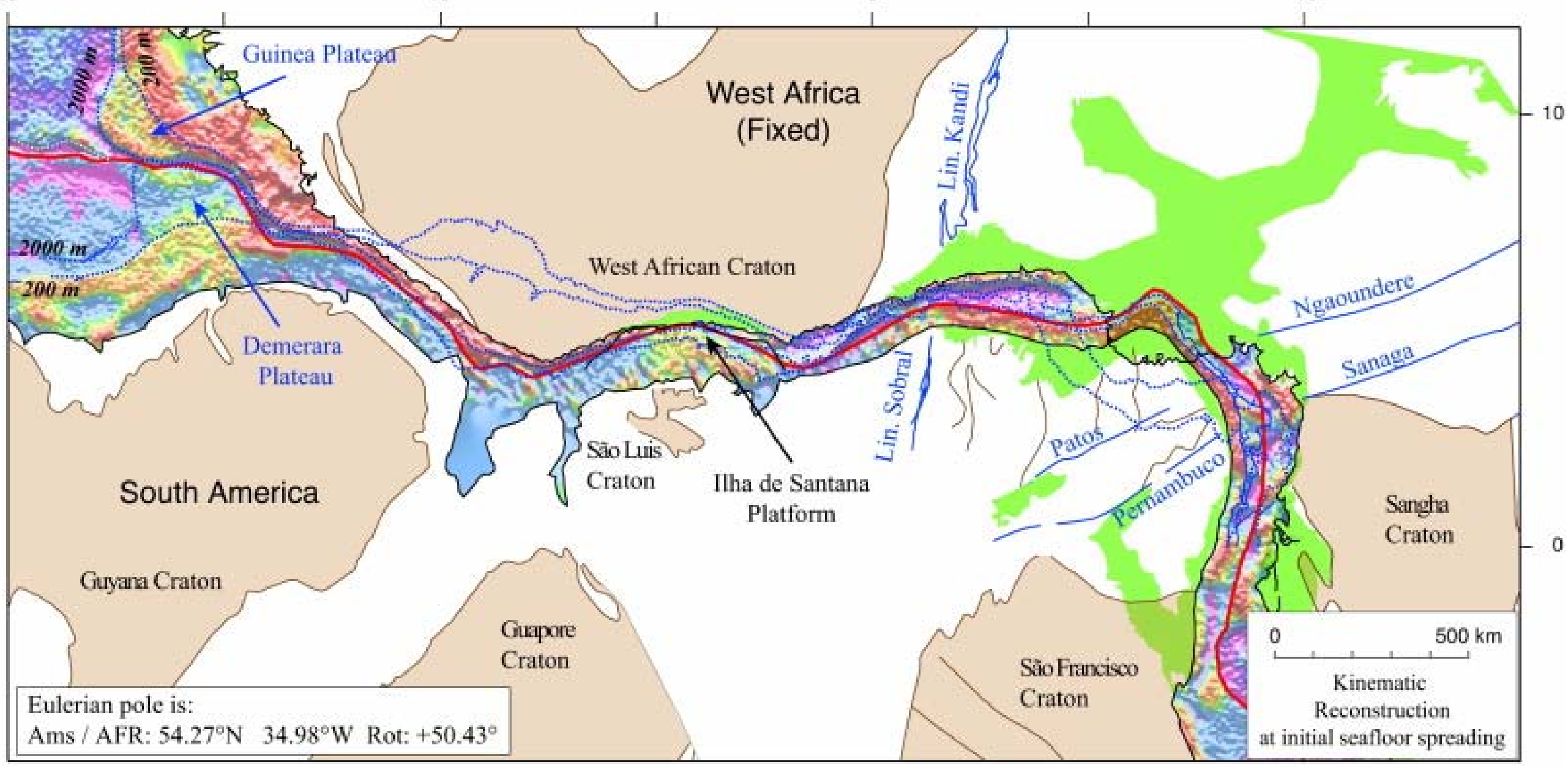

$\begin{aligned} & \text { Basins } \\ & \square \text { Craton }\end{aligned} \begin{aligned} & \text { Main structural constraints } \\ & \text { used for the kinematic fit }\end{aligned}-$ Ridge at Initial Seafloor spreading


Figure 10: Initial reconstruction of the Equatorial Atlantic Ocean proposed by this study. The figure shows, on each plate, the gravity data from Sandwell \& Smith (1997) between the coast and the break up. The Africa Plate, and its attached gravity grid, is fixed; the South American plate and gravity grid have been rotated, following the direction of the small circles shown on figure 9 . The heavy red line shows the breakup separation between the plates by an incipient seafloor spreading. Note the remarkable alignment of the conjugate pre-breakup fault systems (in blue: Kandi/Sobral, Patos/Ngaoundere, Pernambuco/Sanaga lineaments and Demerara/Guinea plateaus), which is also corroborated by geophysical data (Fainstein \& Milliman, 1979). Note also the homology of the $200 \mathrm{~m}$ and $2000 \mathrm{~m}$ isobaths, extracted from Gebco97, on each plate, except in the Amazon and Niger deltas (where important accumulation of Cenozoic sediments occurred. Same geological structure legends as in Figure 2. Mercator projection. See Table 2 for the Eulerian poles used in this figure. 


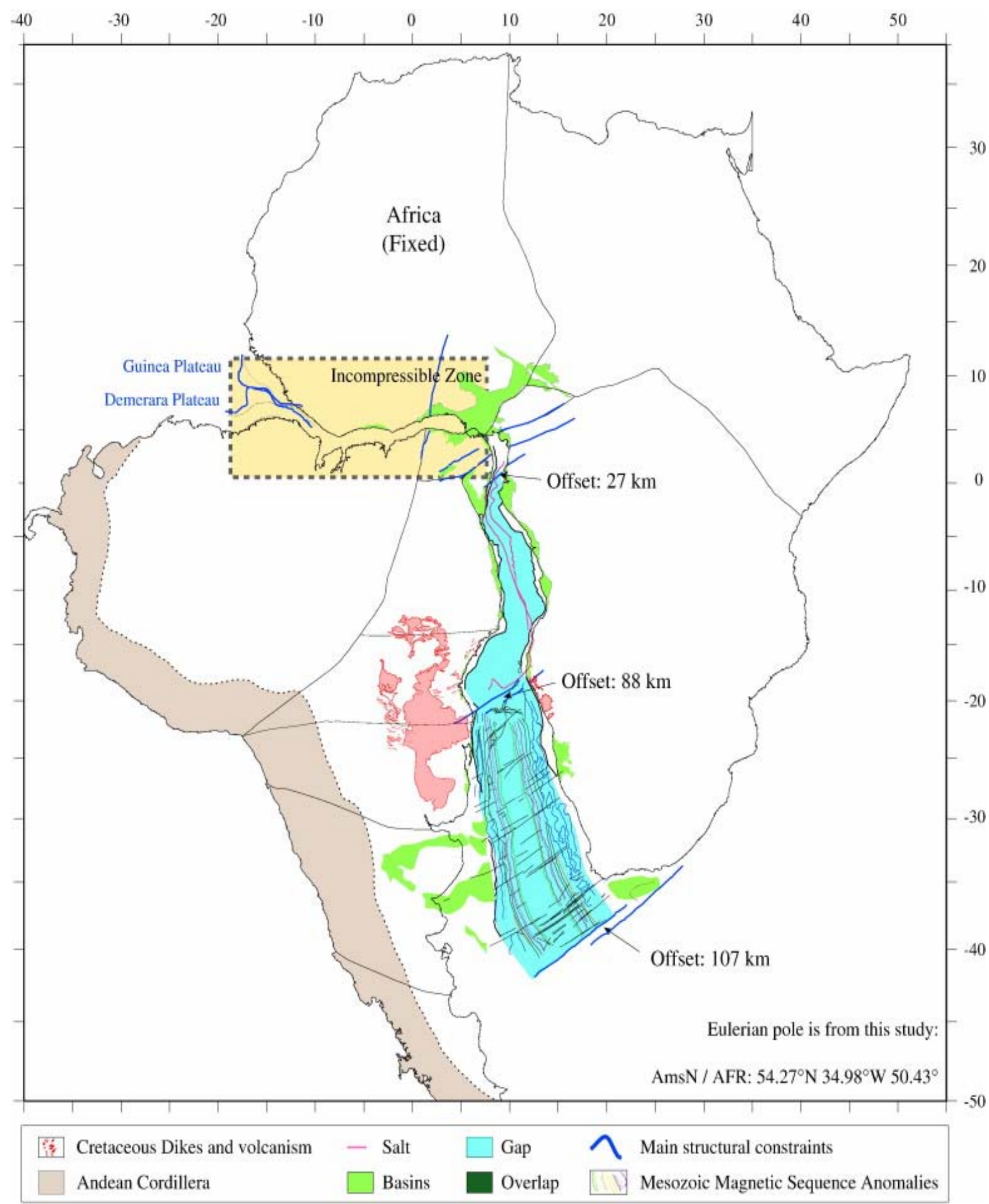

Figure 11: Consequences of the Equatorial fit (figure 10) in the rest of the South Atlantic Ocean. The West Africa block is considered as the fixed plate. The yellow box represents the incompressible zone of the Equatorial segment, which means that no additional movement occurred in this area. Overlaps between the hinge lines are in green, gaps in blue. Pink lines represent the salt boundaries. Mesozoic magnetic anomalies are the same colors as in 
Figures 3 and 4. The large gap shown on this reconstruction illustrates the impossibility, already described by Bullard et al. (1965), to close together the Equatorial, Central and Austral segments, The Ascension, Rio Grande and Falkland fracture zones present an offset of respectively 27, 88 and $107 \mathrm{~km}$. Same geological structure legends as in Figure 2 . Mercator projection. See Table 2 for the Eulerian poles used in this figure. 


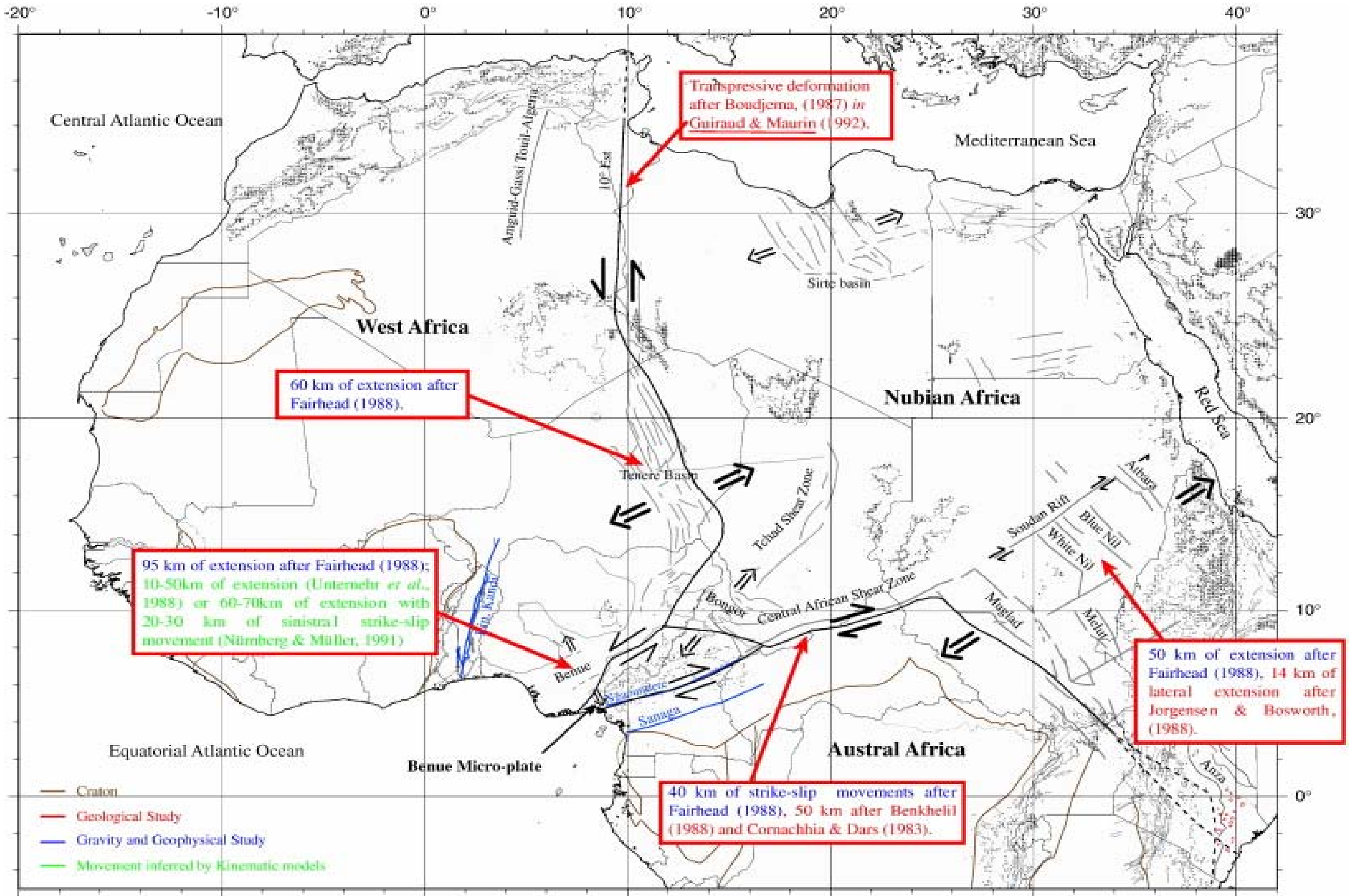


Figure 12: General structural map of the African plate. We have reported on this map a compilation of the published geological and geophysical data concerning the Cretaceous basins (quantitative and qualitative information) and maximum continental deformation on the African plate. The origin of information is given by different colours (red for geology, blue for geophysical and green for kinematic models). Following Guiraud \& Maurin (1992), we dissociated the Africa plate in four blocks: the West Africa, the Nubian, the Austral blocks and the microplate of Benue. The intraplate deformation between these blocks is summarized on a single line (thick black lines) for a graphic purpose. Mercator projection. 


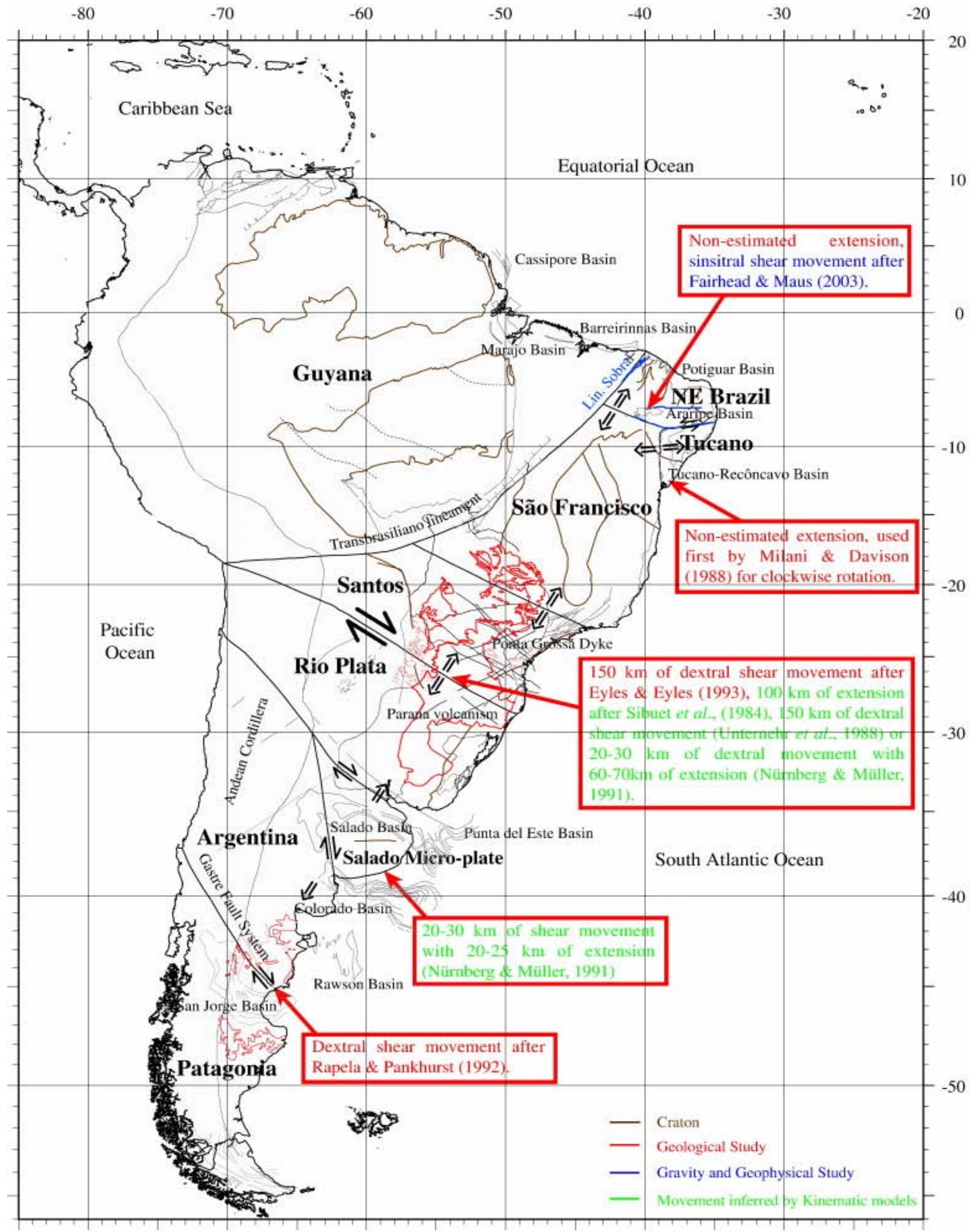


Figure 13: General structural map of the South American plate. We have reported on this map a compilation of the published geological and geophysical data on Cretaceous basins (quantitative and qualitative inofrmation) and maximum continental deformation on the South American plate. The origin of information is given by different colours (red for geology, blue for geophysical and green for kinematic models). We individualized in the South American plate nine blocks: the Guyana, the NE-Brazil, the Tucano, the São Francisco craton, the Santos, the Rio de la Plata, the Argentina, the Patagonia blocks, and the Salado microplate (see text for details and references). The intraplate deformation in between these blocks is summarized on a single line (thick black lines) for a graphic purpose. Mercator projection.

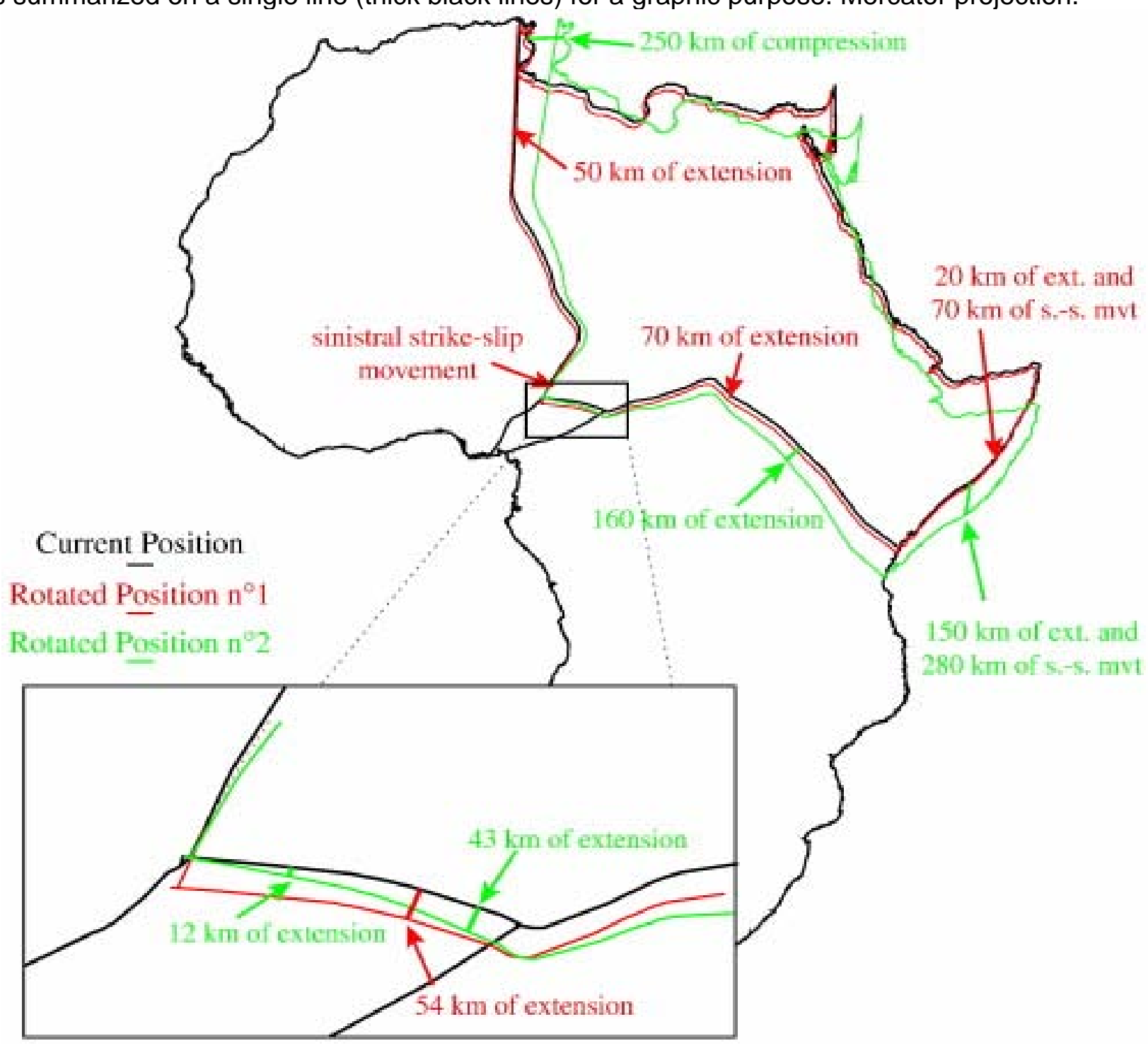


Figure 14: Constraints given by geological and geophysical information on intraplate deformation. The figure presents three positions for the Nubian bock: actual position (black) and two rotated positions (green and red). The inset is a zoom on Nubian and Benoue blocks boundary. The figure shows that a small movement difference in the rotation in the Nubia-Benoue boundary (less than $40 \mathrm{~km}$ ) has dramatic consequences on the rest of the limits of the Nubian block: the quantity of deformation can increase noticeably and the style of deformation can even reverse. Conversely, even qualitative information (for instance, the type of Lineament of $10^{\circ}$ East: compressive or extensive) may be used to constraint the reconstruction: for example, the proposed rotation $\mathrm{N}^{\circ} 2$ is geologically impossible due to the transpressive character of the $10^{\circ}$ East Lineament (Boudjema, 1987, in Guiraud \& Maurin, 1992) 


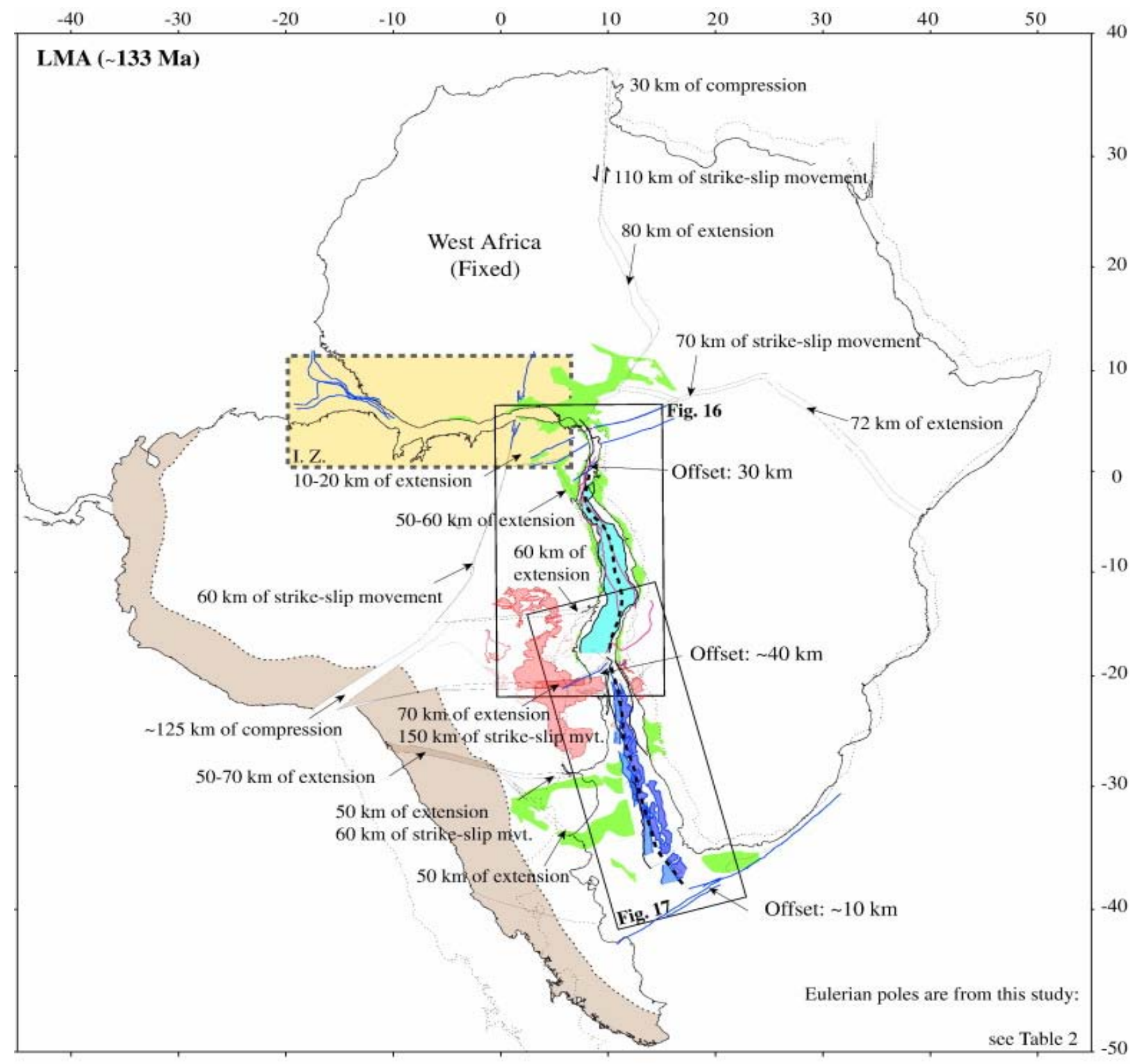

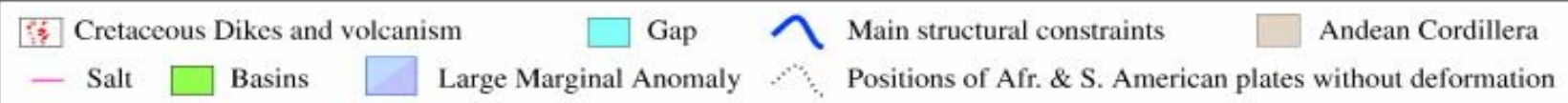


Figure 15: Our reconstruction before the break-up (LMA, $\sim 133 \mathrm{Ma}$, Gradstein et al., 2004). The Africa plate is divided into four blocks. The South America plate is divided into 9 blocks. Both plates are deformed taking into account the cretaceous geological information. The inferred intraplate deformations are indicated in black. This figure shows the tightest possible reconstruction according to geological and geophysical information (see text and Figures 6 and 17 for details). A dextral strike-slip movement of $150 \mathrm{~km}$ persists in the Paraná Basin, which is consistent with the deformation proposed by Eyles \& Eyles (1993). This reconstruction also implies 70km of extension in the Paraná Basin, $125 \mathrm{~km}$ of compression in the Andean Mountains and 50 to $70 \mathrm{~km}$ of extension distributed in the Colorado-Salado Basins and in the Andes. The West Africa block is considered as the fixed plate. Eulerian poles are given in table 2. Mercator projection. See Table 2 for the Eulerian poles used in this figure. 


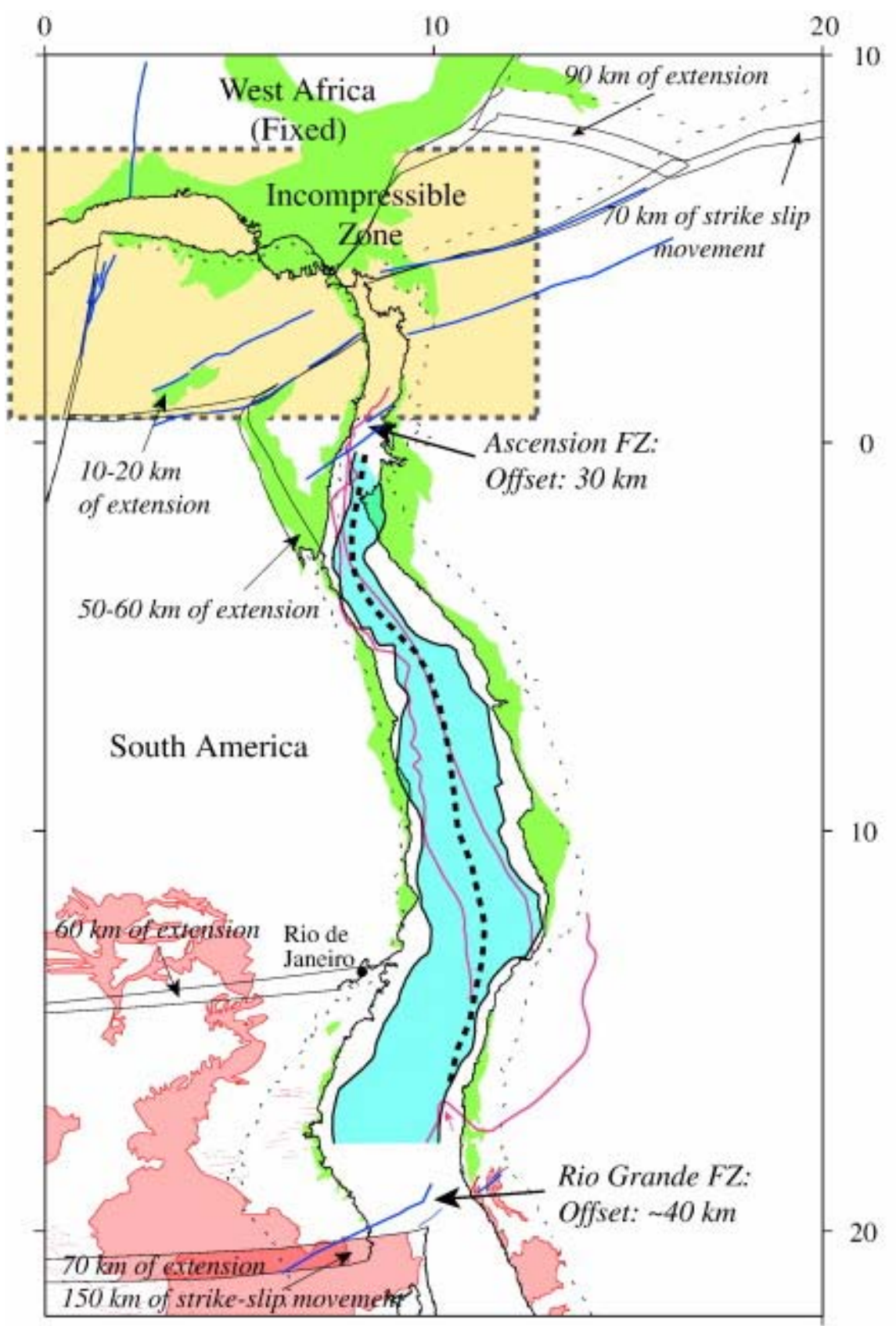

\begin{tabular}{|l|l|}
$\square$ Basins $\quad \begin{array}{l}\text { Cretaceous } \\
\text { Dikes and volcanism }\end{array}$ \\
Gap \\
Preak-up line $\quad$ Hinge line \\
Plates without deformation \\
Main structural constraints
\end{tabular}

Figure 16: Zoom of the tightest pre-break-up fit in the Central Segment of the South Atlantic Ocean (see position in figure 15). The West Africa block is considered as the fixed plate. The thick dotted black line represents the future rupture zone. The offset of the fracture zones remains acceptable. Pink lines represent the external limits of the Aptian salt layer on each plate. These limits overlap over 90-100 km; the hinge lines 
(thick black lines) are still separated by $200-300 \mathrm{~km}$, (blue area), which implies strong consequences on passive margin genesis in the Central segment (Moulin et al., 2005; Aslanian et al., 2009). Eulerian poles are given in table 2. Mercator projection. See Table 2 for the Eulerian poles used in this figure. 


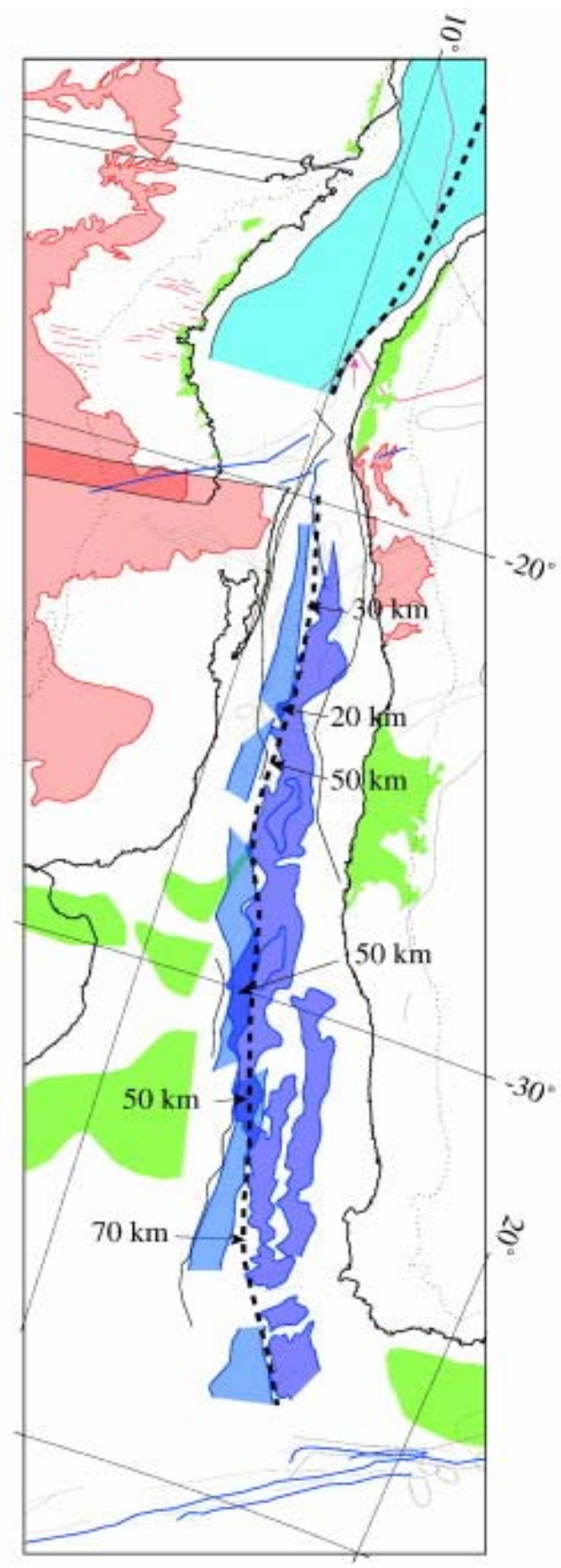

Basins Cretaceous Dikes and volcanism

-.. Break-up line - Hinge line Positions of African \& South American plates without deformation

Main structural constraints - Salt

Large Marginal Anomaly $\quad \square$ Gap प Overlap 
Figure 17: Zoom of the tightest pre-break-up fit in the Austral Segment of the South Atlantic Ocean (see position in figure 15). The West Africa block (not shown on this figure) is considered as the fixed plate. The African LMA is in dark blue and the South American LMA light blue. This reconstruction shows a general good fit between the magnetic anomalies. However, some gaps or overlaps still exist due either to the sparcity of the data, the presence of a boundary or a smaller segmentation, and the oceanic propagator (pink arrow) is not aligned with the spreading ridges south of the Rio Grande Fracture Zone (see text for details). The thick dotted black line represents the future rupture zone. For the geological structures represented, we used the same legend as in Figure 2. Oblique Mercator projection. See Table 2 for the Eulerian poles used in this figure. 


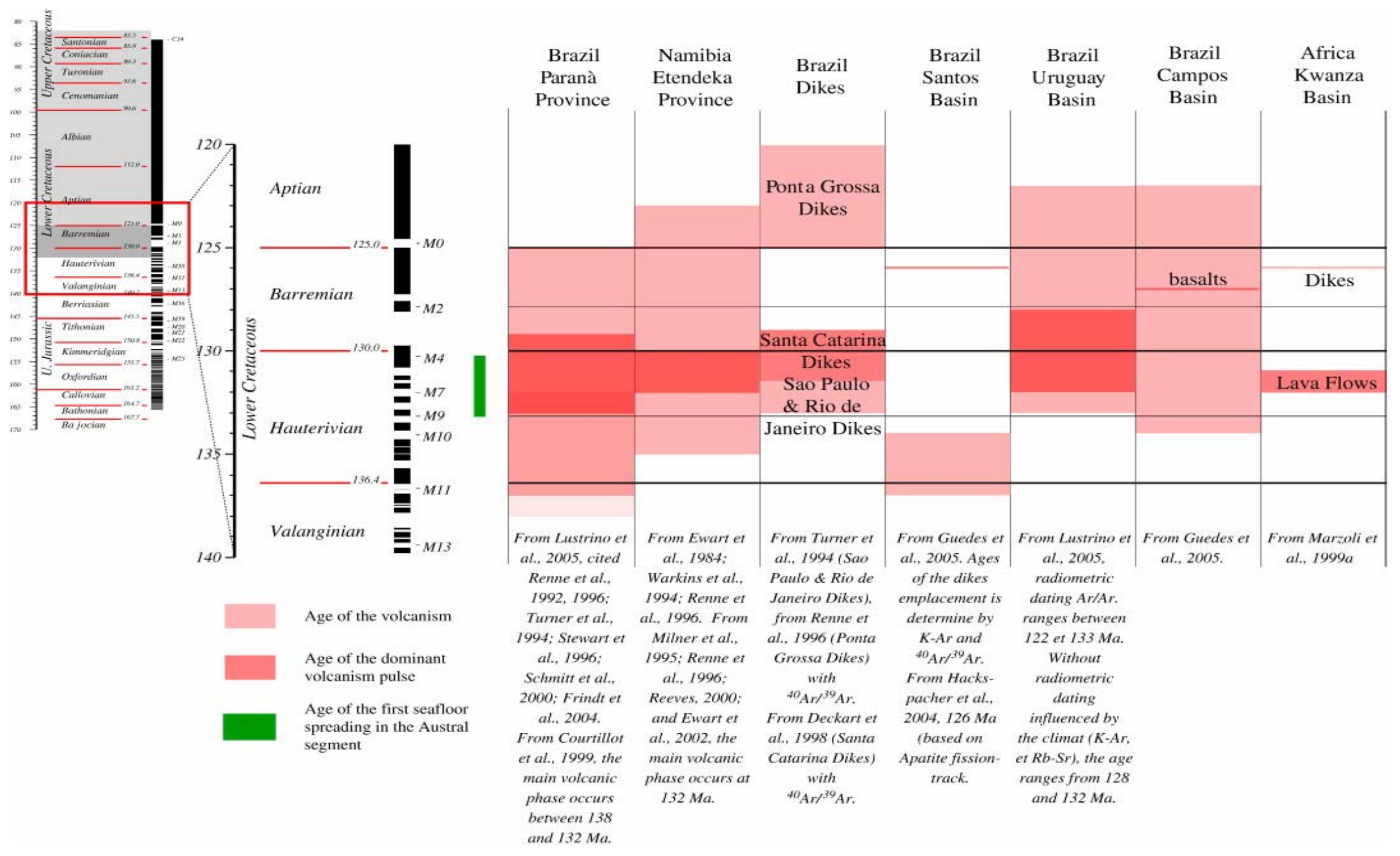


Figure 18: Chrono-stratigraphic chart (Gradstein et al., 2004) for the Lower Cretaceous to the Upper Cretaceous, in connection with a synthesis of volcanic ages known in this area. 


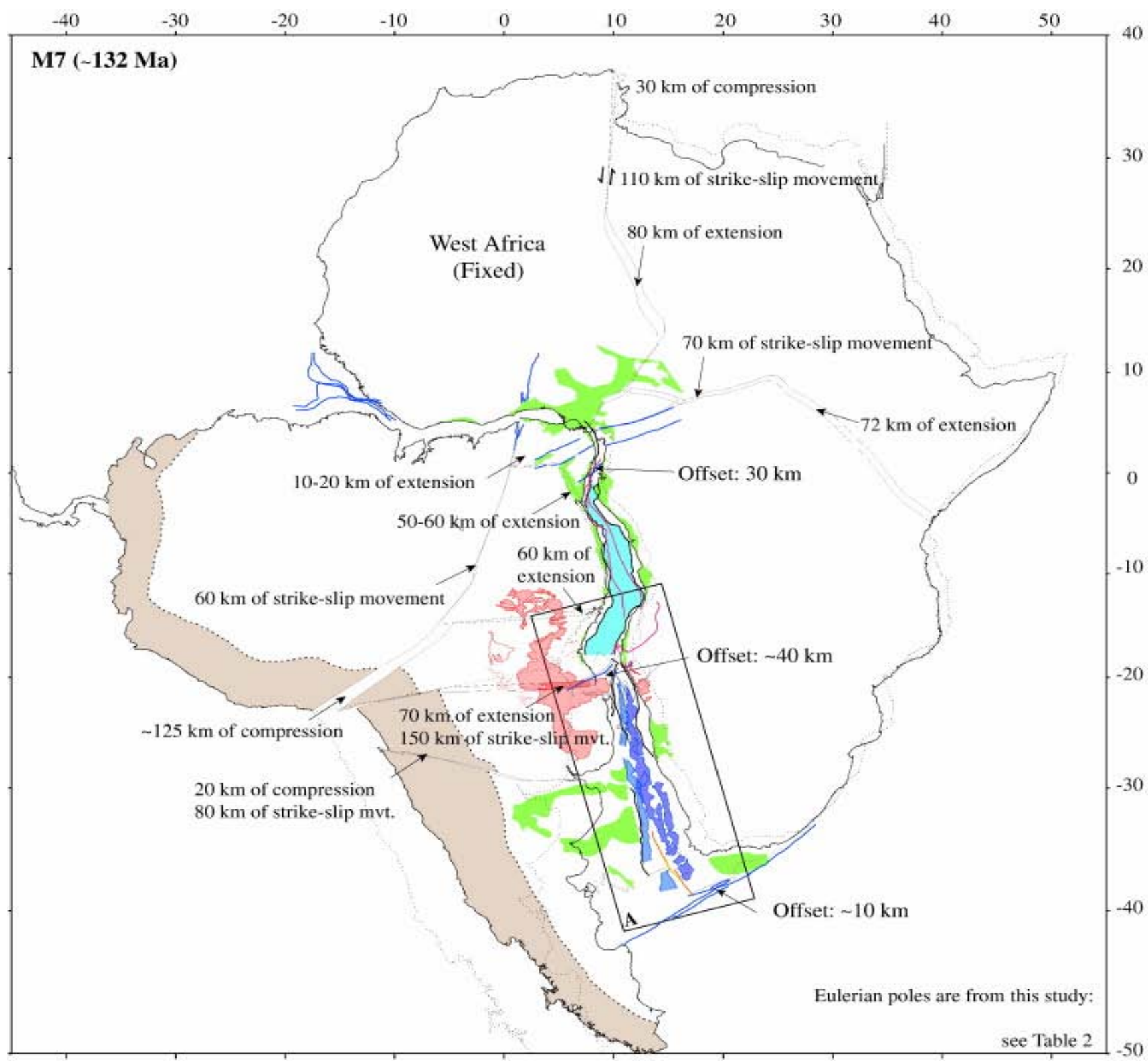

40

$-50$

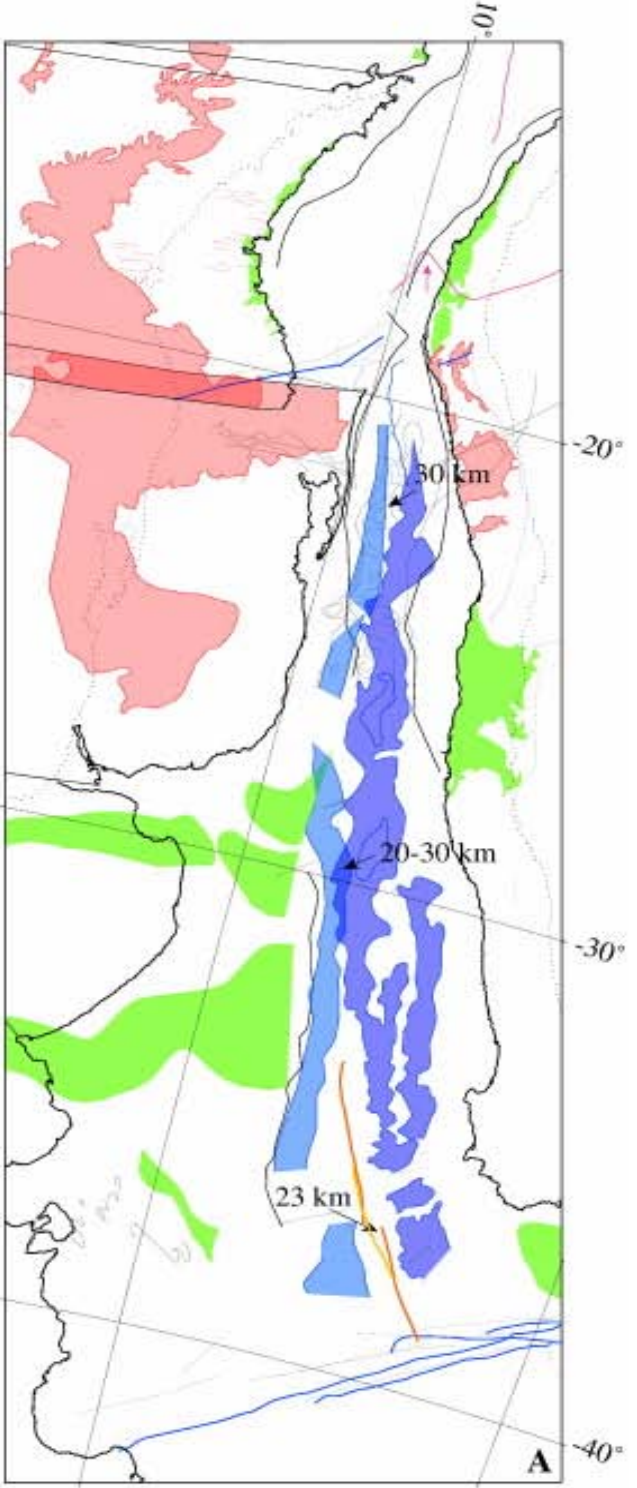


Figure 19: Our South Atlantic Ocean reconstruction at Chron M7 (132 Ma, (Gradstein et al., 2004). Mercator projection. A) Zoom of the Austral Segment (Oblique Mercator Projection). The Salado and Argentina blocks are moved to adjust the magnetic anomalies (orange thick line for the African side, and yellow thick line for the South American side). The rest of the blocks remain in pre-break-up position (figures $16,17 \& 18$ ). This reconstruction implies 80 $\mathrm{km}$ of sinistral strike-slip movement in the Salado Basin, which are not documented. The West Africa block is considered as the fixed plate. For the geological structures represented, we used the same legend as in Figure 2. See Table 2 for the Eulerian poles used in this figure. 


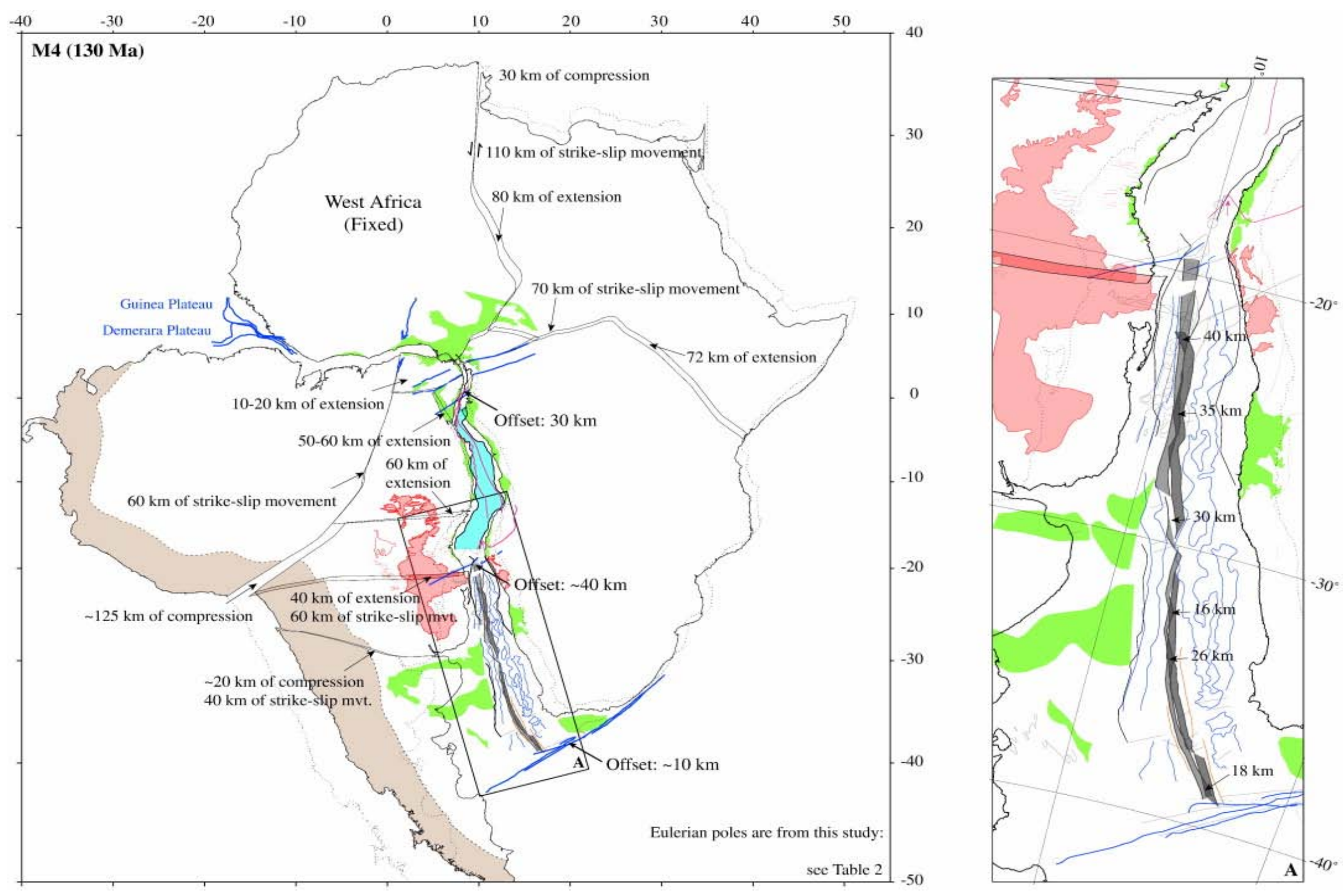


Figure 20: Our South Atlantic Ocean reconstruction at Chron M4 (boundary Barremian / Hauterivian, 130 Ma, (Gradstein et al., 2004)). The deformation in the Central segment is identical to those previously shown, except in the Paraná Basin where the deformation corresponds to $40 \mathrm{~km}$ of extension associated with $60 \mathrm{~km}$ of dextral strike-slip motion. This reconstruction implies a more intensive intra-plate deformation. The Santos block is detached from the São Francisco plate; it moves westwards following the Rio de la Plata and the Salado-Argentina blocks. These additional movements minimize the deformation in the vicinity of the Paraná Basin and imply 60km of extension in the northern part of the Santos-Plate and $20 \mathrm{~km}$ of compression in the Andean Mountains. Note in the south segment the perfect symmetry of the magnetic anomalies M4 (dark grey for the African side, and light grey for the South American side). The West Africa block is considered as the fixed plate and we used the same legend as in Figure 2 for the geological structures. For the magnetic anomalies, we used the same colours as in Figures 3 and 4. The map is in Mercator projection. See Table 2 for the Eulerian poles used in this figure.

Right (A): Zoom of the South Segment in order to illustrate the assembly of the magnetic anomalies M4. The other magnetic anomalies are represented in the same colours as in Figures 3 and 4 . The projection of the map is Oblique Mercator. 


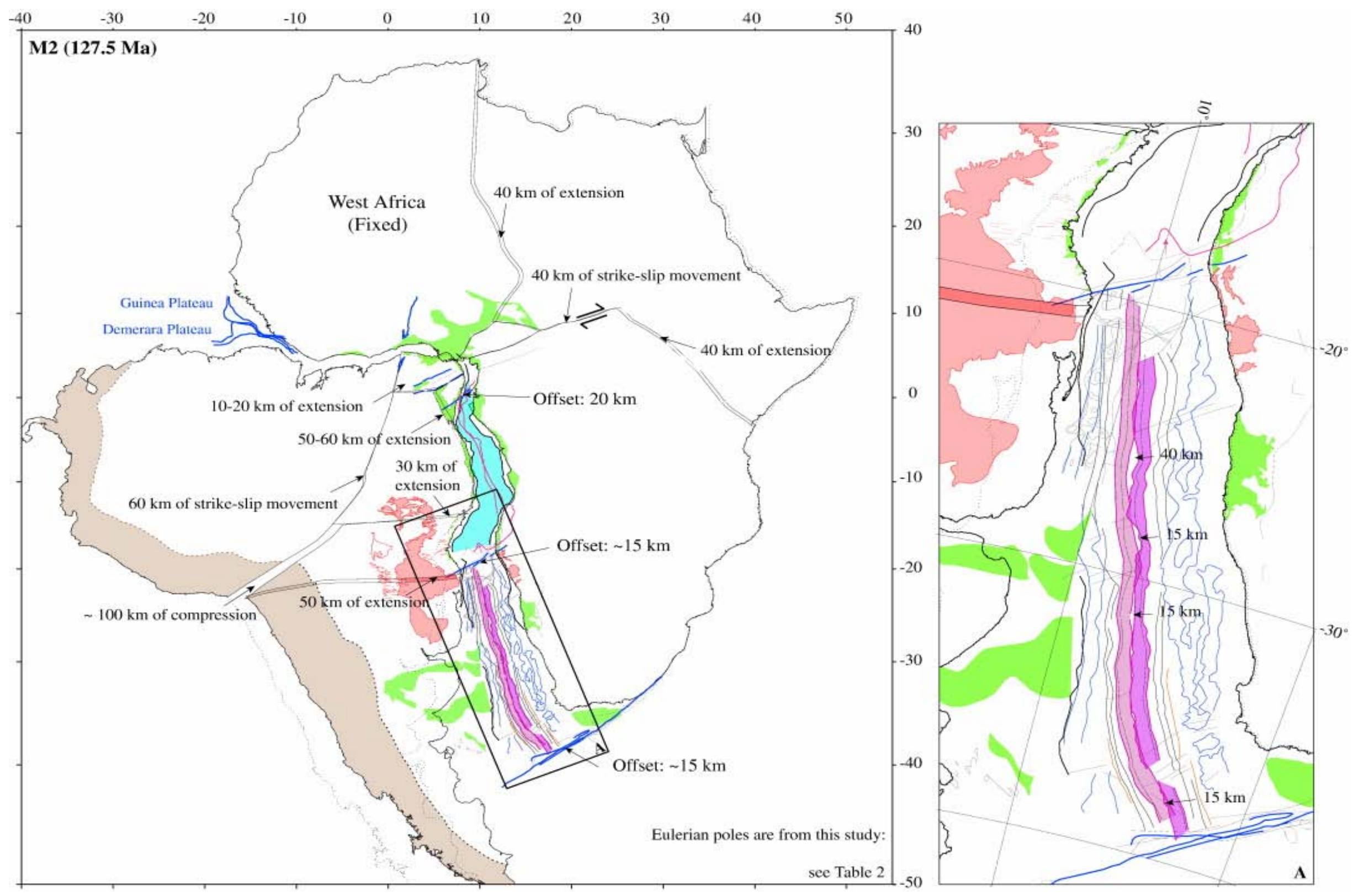


Figure 21: Our South Atlantic Ocean reconstruction at Chron M2 ( 127.5 Ma, Mid-Barremian (Gradstein et al., 2004)). The deformation in the Central Segment is identical to those previously shown, except in the Paraná basin. This reconstruction implies $30 \mathrm{~km}$ of extension associated with $40 \mathrm{~km}$ of dextral strike motion. Note in the South Segment the perfect symmetry of the magnetic anomalies M2 (dark pink for the African side, and light pink for the South American side), without any additional intra-plate deformation: the four southern blocks move with the same relative pole. Between Chrons M2 and M4, the Santos block stops to move independently and becomes linked of the São Francisco block. The West Africa block is considered as the fixed plate and we used the same legend as in Figure 2 for the geological structures. For the magnetic anomalies, we used the same colours as in Figures 3 and 4. The map is in Mercator projection. See Table 2 for the Eulerian poles used in this figure.

Right (A): Zoom of the South Segment in order to illustrate the assemblage of the magnetic anomalies M2. The other magnetic anomalies are represented in the same colours as in Figures 3 and 4. The projection of the map is Oblique Mercator. 


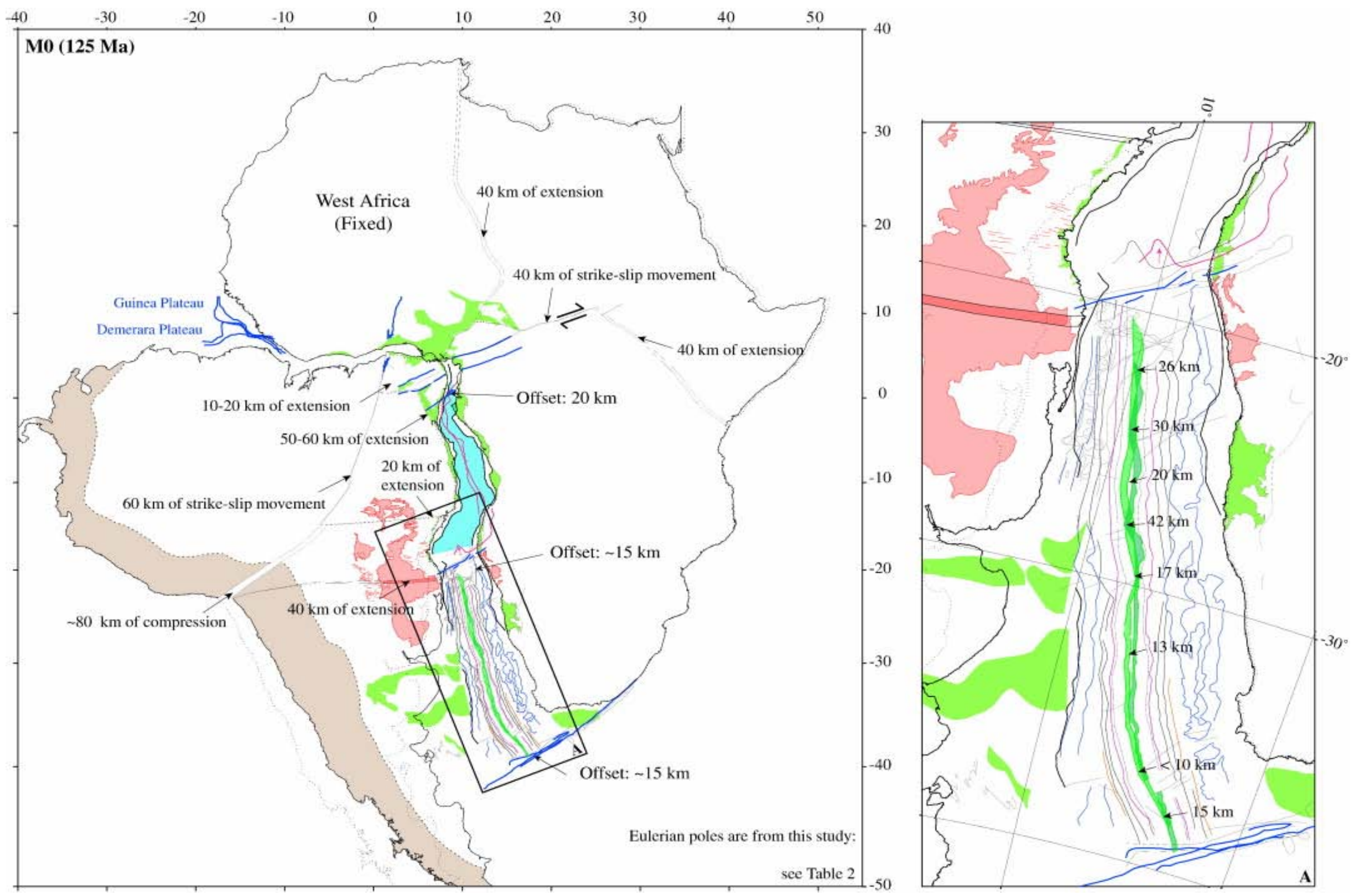


Figure 22: Our South Atlantic Ocean reconstruction at Chron M0 (boundary Aptian / Barremian, 125 Ma, according to Gradstein et al., 2004). The Africa plate undergoes its last phase of deformation. This reconstruction implies in Africa: $72 \mathrm{~km}$ of extension in the Sudan Rift, $70 \mathrm{~km}$ of sinistral strike slip motion along the Central African shear zone, $80 \mathrm{~km}$ of extension in the Tchad Basin, $100 \mathrm{~km}$ of dextral strike-slip motion along the $10^{\circ}$ lineament

and $30 \mathrm{~km}$ of compression in north-eastern part of Algeria. In South America, it implies 10-20 km of extension in the NE-Brazil block, along the Potiguar and Araripe basins, $50-60 \mathrm{~km}$ of extension in the Tucano basin, $60 \mathrm{~km}$ of dextral strike-sli $\mathrm{p}$ motion along the Transbrasiliano lineament. Finally, the deformation in the Paraná basin is limited to $14 \mathrm{~km}$ of extension. Note in the south segment the perfect symmetry of the magnetic anomalies MO (dark green for the African side, and green for the South American side), without any additional intra-plate deformation in the South of South America: the four southern blocks move with the same relative pole. The West Africa block is considered as the fixed plate and we used the same legend as in Figure 2 for the geological structures. For the magnetic anomalies, we used the same colours as in Figures 3 and 4. The map is in Mercator projection. See Table 2 for the Eulerian poles used in this figure.

Right (A): Zoom of the South Segment in order to illustrate the assembly of the magnetic anomalies M0. The other magnetic anomalies are represented in the same colours as in Figures 3 and 4. The projection of the map is Oblique Mercator. 


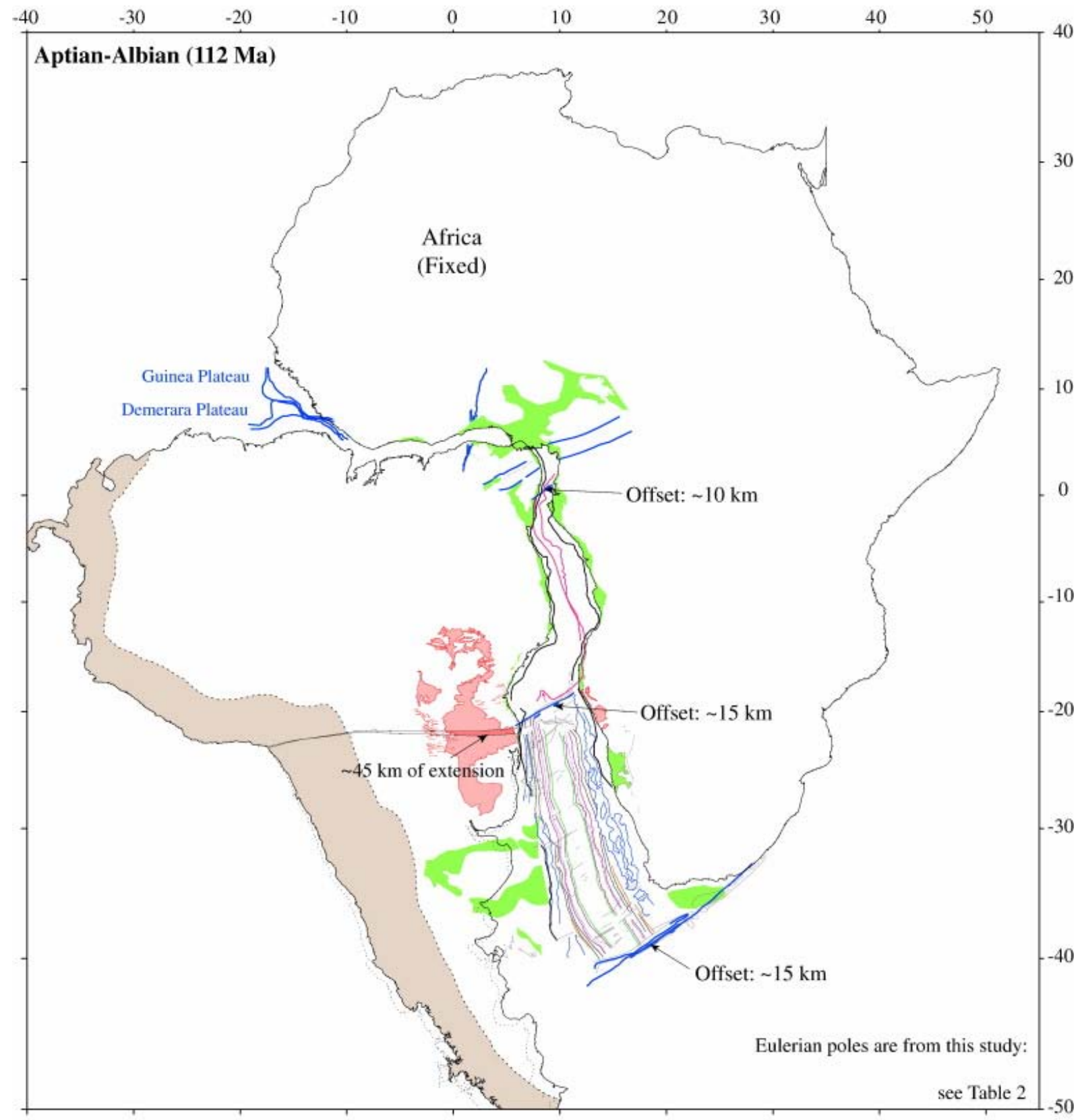

\begin{tabular}{|llll|}
\hline $1 ;$ & Cretaceous Dikes and volcanism & - Salt & Main structural constraints \\
$\square$ & Andean Cordillera & $\square$ Basins & Mesozoic Magnetic Sequence Anomalies \\
\hline
\end{tabular}

Figure 23: Our South Atlantic Ocean reconstruction at Upper Aptian - Lower Albian time (112Ma).

It is impossible to adjust the $\mathrm{FZ}$ in the southern segment with a rigid South American plate. A deformation persists in the Paraná Basin, associated with $45 \mathrm{~km}$ of extension. The West Africa block is considered as the fixed plate and we used the same legend as in Figure 2 for the geological structures represented. The map is in Mercator projection. See Table 2 for the Eulerian poles used in this figure. 


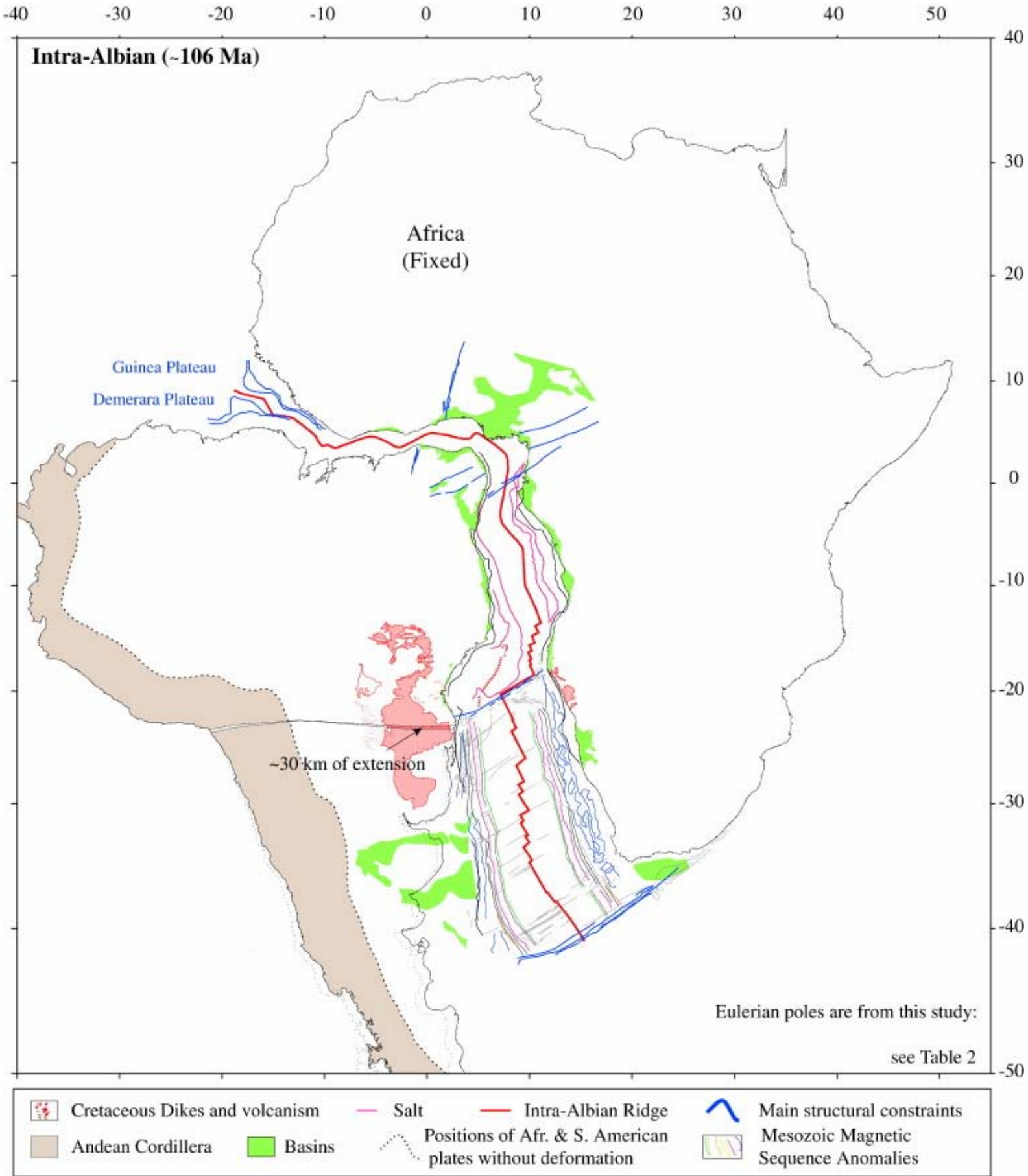

Figure 24: Our South Atlantic Ocean reconstruction at Intra-Albian time (106 Ma). It is impossible to adjust the $\mathrm{FZ}$ in the southern segment with a rigid South American plate. A deformation persists in the Paraná Basin, associated with $30 \mathrm{~km}$ of extension The red line represents the accreting ridge at this time (Intra-Albian), located eastwards of the Aptian salt basin in the Brazilian margin. The West Africa block is considered as the fixed plate and we used the same legend as in Figure 2 for the geological structures represented. The map is in Mercator projection. See Table 2 for the Eulerian poles used in this figure. 

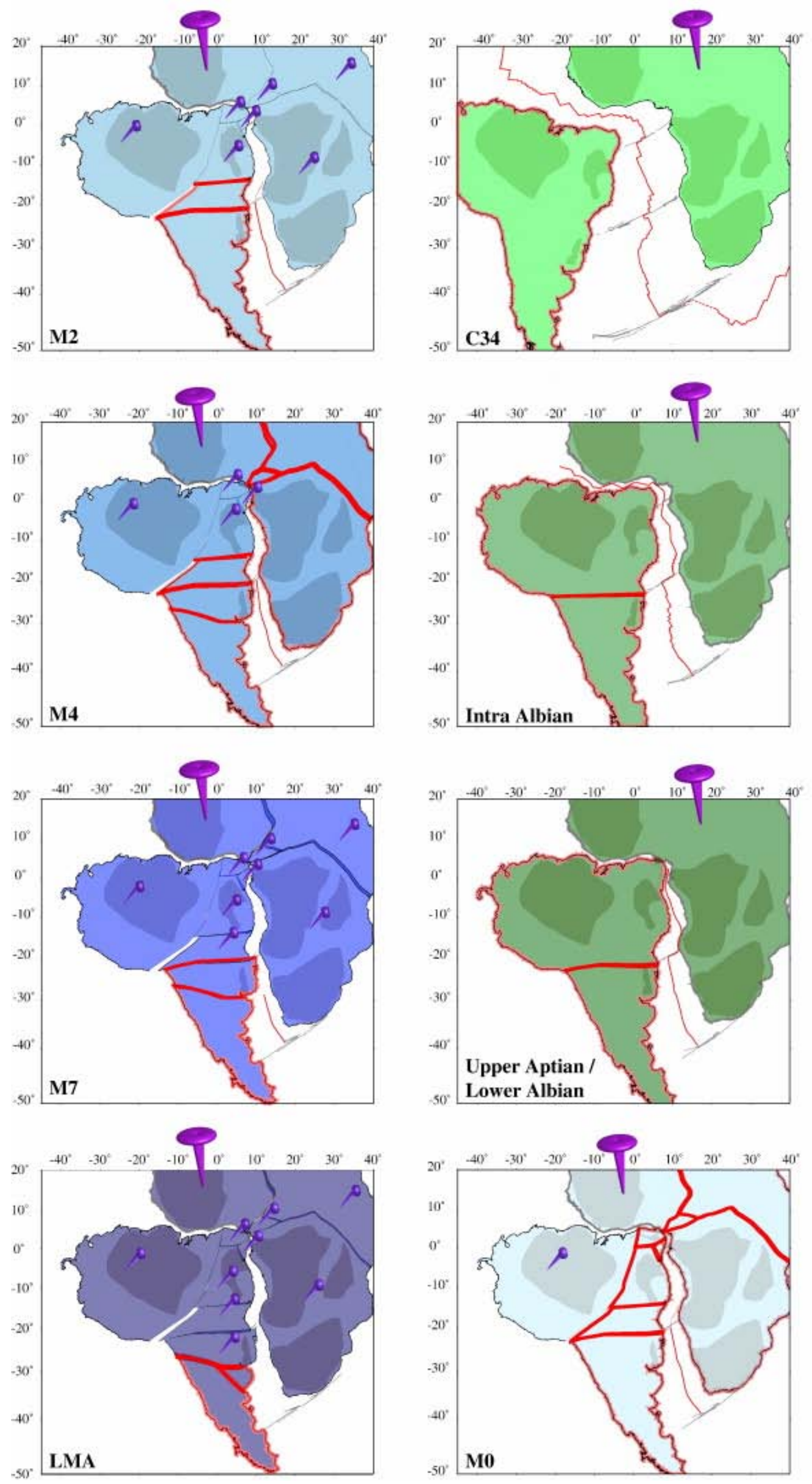
Figure 25: New initial evolution of the Equatorial and South Atlantic Oceans from ante-M9 to C34 proposed by this study, from LMA ( 133 Ma), M7 ( 132 Ma), M4 (130 Ma), M2 (127,5 Ma), M0 (125 Ma), Late Aptian (112 Ma); Intra-Albian (106 Ma) and C34 (84 Ma). The West Africa block is considered as the fixed plate (large mauve nail). The small mauve nails symbolize that the block does not move, in respect to the West Africa block, for this period. Large red lines give the location of the intra-plate deformation between two chrons. The coasts of the moving plates are underlined in orange. See Table 2 for the Eulerian poles used in this figure.

\section{Tables}


Table 1. Finite Rotations used for the historic (with respect to West Africa), classed by authors and by order of apparition on figures (see Figures 5, 6, 7 and 8).

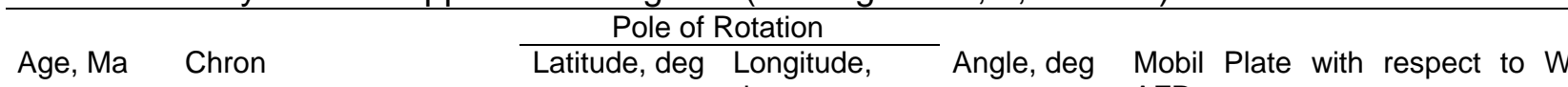
deg AFR

\subsection{Fit Bullard et al., 1965}

130

4.4. Fit Rabinowitz \& LaBrecque, 1979

130 (140.2) $\quad$ Ano G

45.5

47

$-33.8$

55.10

19.0

165 (125) MO

165 (125) MO

165 (125) M0

4.4.3. Fit Curie, 1984

$117(130) \quad M 4$

$117(130) \quad M 4$

4.5. Fit Nürnberg \& Müller, 1991

150 (150.8) Tithonian

150 (150.8) Tithonian

150 (150.8) Tithonian

150 (150.8) Tithonian

150 (150.8) Tithonian

150 (150.8) Tithonian

4.6. Fit Lawver et al., 1999

$\begin{array}{ll}130(\sim 133) & \text { M9 } \\ 130(\sim 133) & \text { M9 } \\ 130(-133) & \text { M9 }\end{array}$

Fit Schettino \& Scotese, 2005

140

140

140

140

140

140

4.7. Fit König \& Jokat, 2006

$\begin{array}{ll}130 \text { (134) } & \text { M10 } \\ 167.2 & \text { JQZ } \\ 167.2 & \text { JQZ } \\ 167.2 & \text { JQZ } \\ 167.2 & \text { JQZ }\end{array}$

49.352

$-32.10$

$-33.013$

$-33.44$

$-34.088$

$-32.532$
57 Ams / W. AFR

57.5 Ams / W. AFR

$58 \quad$ Ams / W. AFR

50.9 Ams / W. AFR

-8 Afr Austral / W. AFR

-8 Afr Nubia / W. AFR

49.4

55.5

Guy., NEB, Tuc., SF Santos / W. AFR Plata, Sal. Arg. /W. AFR

55.885

56.307

56.583

56.375

1.5

1.5

Guy., NEB, Tuc., SF Santos / W. AFR

Plata / W. AFR

Argentina / W. AFR

Salado / W. AFR

Austral / W. AFR

Nubia / W. AFR

Guy., NEB, Tuc., SF Santos / W. AFR

Plata / W. AFR

Argentina / W. AFR

54.507

55.051

56.13

55.743

$-3.44$

$-4.15$

Guy., NEB, Tuc., SF Santos / W. AFR

Plata / W. AFR

Argentina / W. AFR

Salado / W. AFR

Austral / W. AFR

Nubia / W. AFR

4.8. Fit Eagles, 2006 
Table 2. Finite Rotations for Equatorial and South Atlantic Oceans during Mesozoic Evolution used in this study (with respect to the fixed West Africa block). The ages are given according to timescale from Gradstein et al., 2004. See Figures 2, 15, 19, 20, 21, 22, 23 and 24.

\begin{tabular}{lllcll}
\hline & & \multicolumn{2}{c}{ Pole of Rotation } & & \\
\cline { 3 - 4 } Age (Ma) & Chron & Latitude, deg & Longitude, deg & Angle, deg & Source \\
\hline \multirow{2}{*}{ 4.9. Ams (Guyana) with respect to $\mathbf{W}$ W. Africa } & & & & \\
84 & C34 & 61.66 & -34.37 & 33.55 & Campan, 1995 \\
$\sim 106$ & Intra-Albian & 55.43 & -34.9 & 46.75 & This study \\
112 & Aptian-Albian & 54.27 & -34.98 & 50.43 & This study \\
125 & M0 & 54.27 & -34.98 & 50.43 & This study
\end{tabular}

4.10. NE Brazil with respect to $W$. Africa

$\begin{array}{llcccl}84 & \text { C34 } & 61.66 & -34.37 & 33.55 & \text { Campan, } 1995 \\ \sim 106 & \text { Intra- Albian } & 55.43 & -34.9 & 46.75 & \text { This study } \\ 112 & \text { Aptian-Albian } & 54.27 & -34.98 & 50.43 & \text { This study } \\ 125 & \text { M0 } & 55.4 & -36.31 & 49.95 & \text { This study }\end{array}$

4.11. Tucano with respect to $W$. Africa

$\begin{array}{lllcll}84 & \text { C34 } & 61.66 & -34.37 & 33.55 & \text { Campan, } 1995 \\ \sim 106 & \text { Intra- Albian } & 55.43 & -34.9 & 46.75 & \text { This study } \\ 112 & \text { Aptian-Albian } & 54.27 & -34.98 & 50.43 & \text { This study } \\ 125 & \text { M0 } & 58.19 & -38.71 & 48.76 & \text { This study }\end{array}$

4.12. São Francisco with respect to $W$. Africa

$\begin{array}{llcccl}84 & \text { C34 } & 61.66 & -34.37 & 33.55 & \text { Campan, } 1995 \\ \sim 106 & \text { Intra- Albian } & 55.43 & -34.9 & 46.75 & \text { This study } \\ 112 & \text { Aptian-Albian } & 54.27 & -34.98 & 50.43 & \text { This study } \\ 125 & \text { M0 } & 53.65 & -35.44 & 51 & \text { This study }\end{array}$

4.13. Santos with respect to $W$. Africa

$\begin{array}{lll}84 & \text { C34 } & 61.66 \\ \sim 106 & \text { Intra- Albian } & 55.43 \\ 112 & \text { Aptian-Albian } & 54.27 \\ 125 & \text { M0 } & 52.85 \\ 127.5 & \text { M2 } & 52.05 \\ 130 & \text { M4 } & 52.11 \\ 132 & \text { M7 } & 52.11 \\ 133 & \text { LMA } & 52.11\end{array}$

$\begin{array}{lll}-34.37 & 33.55 & \text { Campan, 1995 } \\ -34.9 & 46.75 & \text { This study } \\ -34.98 & 50.43 & \text { This study } \\ -34.85 & 52.02 & \text { This study } \\ -34.51 & 52.51 & \text { This study } \\ -34.64 & 52.99 & \text { This study } \\ -34.64 & 52.99 & \text { This study } \\ -34.64 & 52.99 & \text { This study }\end{array}$

4.14. Plata with respect to $W$. Africa

$\begin{array}{llr}84 & \text { C34 } & 61.66 \\ \sim 106 & \text { Intra- Albian } & 53.65 \\ 112 & \text { Aptian-Albian } & 52.622 \\ 125 & \text { M0 } & 51.66 \\ 127.5 & \text { M2 } & 51.76 \\ 130 & \text { M4 } & 52.73 \\ 132 & \text { M7 } & 51.56 \\ 133 & \text { LMA } & 51.56\end{array}$

$-34.37$

$-34.88$

$-35.214$

$-34.99$

$-35.07$

$-35.12$

$-34.58$

$-34.58$

$-34.37$

$-34.88$

$-35.214$

$-34.99$

$-35.07$

$-35.34$

$-35.25$

$-35.51$

$-34.37$

$-34.88$

$-35.214$

$-34.99$

$-35.07$
33.55

47.14

50.85

52.5

52.83

53.63

54.75

54.75

33.55

47.14

50.85

52.5

52.83

53.29

53.98

54.75

33.55

47.14

50.85

52.5

52.83
Campan, 1995

This study

This study

This study

This study

This study

This study

This study

Campan, 1995

This study

This study

This study

This study

This study

This study

This study

Campan, 1995

This study

This study

This study

This study 


$\begin{array}{llllll}130 & \text { M4 } & 52.67 & -35.34 & 53.29 & \text { This study } \\ 132 & \text { M7 } & 52.66 & -35.43 & 53.73 & \text { This study } \\ 133 & \text { LMA } & 52.82 & -35.98 & 54.27 & \text { This study }\end{array}$

4.16. Austral with respect to $W$. Africa

$\begin{array}{lll}112 & \text { Aptian-Albian } & \\ 127.5 & \text { M2 } \\ 130 & \text { M4 }\end{array}$

$0 \quad 0$

$\begin{array}{lll}27 & -18 & -0.1\end{array}$

$-0.1$

This study (modified from Guirand

$27-18$

$-1.5$

\& Maurin, 1992)

$-18$

This study (modified from Guirand \& Maurin, 1992)

Afr Nubia with respect to $W$. Africa

$\begin{array}{llccc}112 & \text { Aptian-Albian } & 0 & 0 & 0 \\ 127.5 & \text { M2 } & 66 & -19 & -0.5 \\ 130 & \text { M4 } & & & \end{array}$

$130 \quad$ M4

27

$-18$

$-2.36$

This study (modified from Guiraud \& Maurin, 1992)

This study (modified from Guiraud \& Maurin, 1992)

4.16.1. Afr Benue with respect to W. Africa

\begin{tabular}{llcccc}
112 & Aptian-Albian & 0 & 0 & 0 & \\
127.5 & M2 & 44 & -84.9 & -0.14 & This study \\
130 & M4 & 13.22 & 1.85 & -2.31 & This study \\
\hline
\end{tabular}

